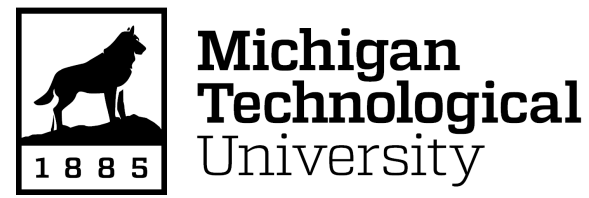

Michigan Technological University Digital Commons @ Michigan Tech

Dissertations, Master's Theses and Master's Reports

2017

\title{
LIFE CYCLE ASSESSMENT (LCA) OF ORE TRANSPORTATION ROUTE ALTERNATIVES FOR EAGLE MINE
}

Soumith Kumar Oduru

Michigan Technological University, soduru@mtu.edu

Copyright 2017 Soumith Kumar Oduru

\section{Recommended Citation}

Oduru, Soumith Kumar, "LIFE CYCLE ASSESSMENT (LCA) OF ORE TRANSPORTATION ROUTE

ALTERNATIVES FOR EAGLE MINE", Open Access Master's Report, Michigan Technological University, 2017.

https://doi.org/10.37099/mtu.dc.etdr/452

Follow this and additional works at: https://digitalcommons.mtu.edu/etdr

Part of the Civil Engineering Commons, Environmental Engineering Commons, and the Transportation Engineering Commons 


\title{
LIFE CYCLE ASSESSMENT (LCA) OF ORE TRANSPORTATION ROUTE ALTERNATIVES FOR EAGLE MINE.
}

\author{
By \\ Soumith Kumar Oduru
}

\begin{abstract}
A REPORT
Submitted in partial fulfillment of the requirements for the degree of

MASTER OF SCIENCE

In Civil Engineering
\end{abstract}

MICHIGAN TECHNOLOGICAL UNIVERSITY

2017

(C) 2017 Soumith Kumar Oduru 
This report has been approved in partial fulfillment of the requirements for the Degree of MASTER OF SCIENCE in Civil Engineering.

Department of Civil and Environmental Engineering

Report Advisor: Dr. Pasi T. Lautala

Committee Member: $\quad$ Dr. David Shonnard

Committee Member: Dr. Robert M. Handler

Department Chair: $\quad$ Dr. Audra Morse 


\section{Table of Contents}

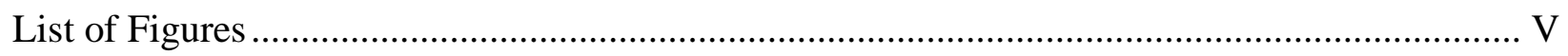

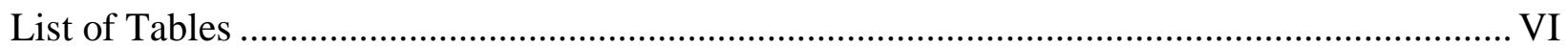

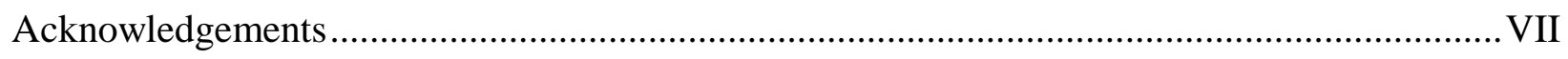

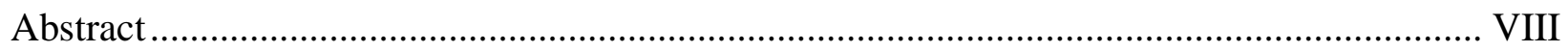

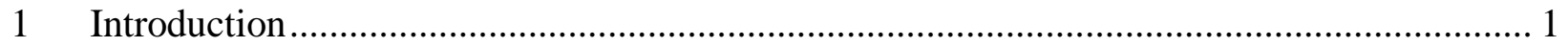

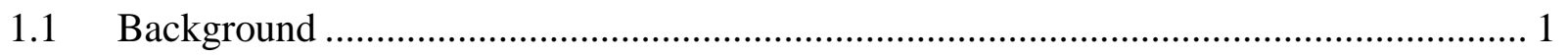

1.2 Study Objectives …………………………………….......................................... 2

1.3 Report Structure .................................................................................................... 2

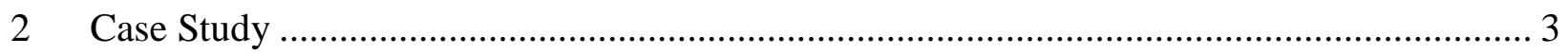

2.1 Eagle Mine ……………………...................................................................... 3

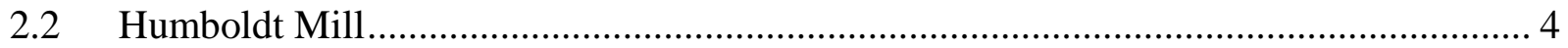

2.3 Ore Transportation and Transportation Alternatives ...................................................... 4

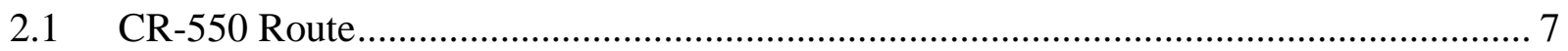

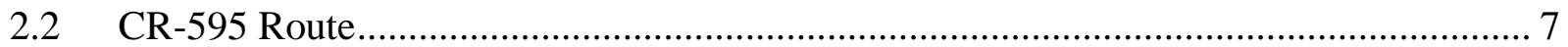

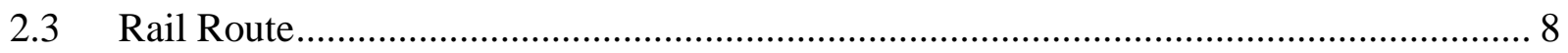

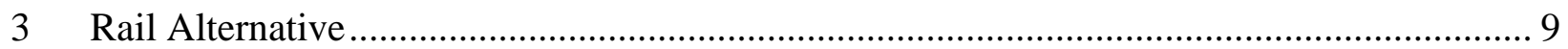

3.1 Stage 1: Conceptual Rail Route Constraints ................................................................. 9

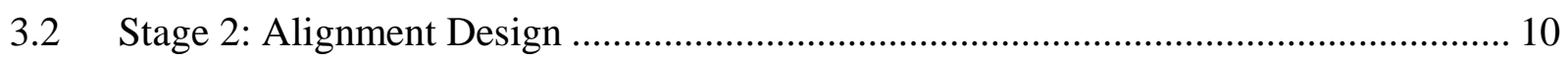

3.3 Operational and Motive Power Considerations …………………………………....... 12

3.4 RTC Simulation and Train Characteristics ................................................................. 13

3.5 Additional Load Carrying Capacity ……………………………………………....... 16

$4 \quad$ Life Cycle Assessment.................................................................................................... 18

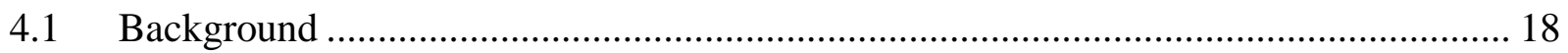

4.2 Literature Review of Life Cycle Assessment in Transportation ..................................... 18

4.2.1 LCA Databases and Tools ............................................................................ 19

4.3 Detailed LCA and Operational LCA..................................................................... 20

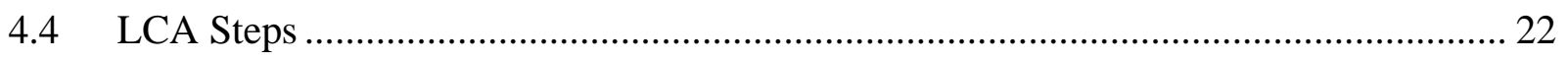

4.4.1 Goal and Scope Definition ........................................................................... 22

4.4.2 Inventory Analysis ............................................................................................. 22 


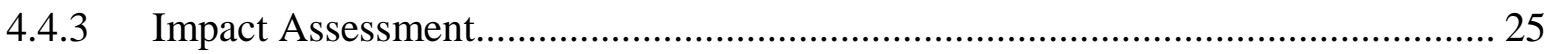

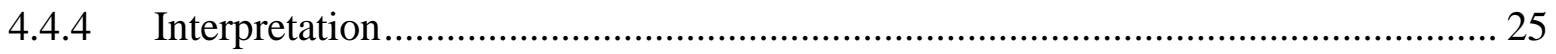

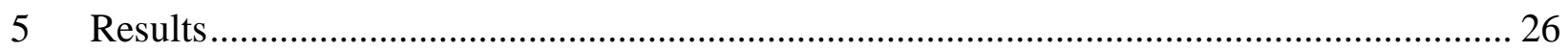

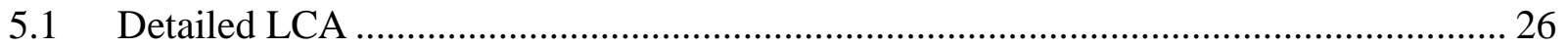

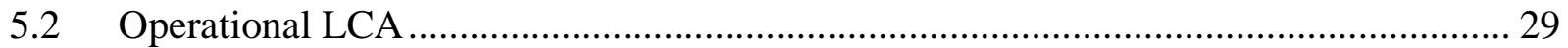

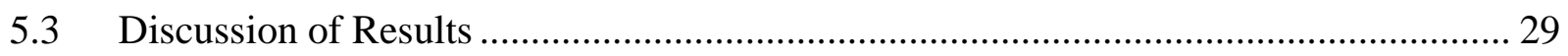

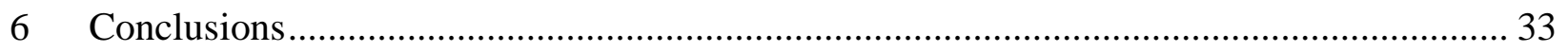

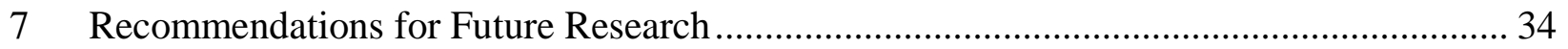

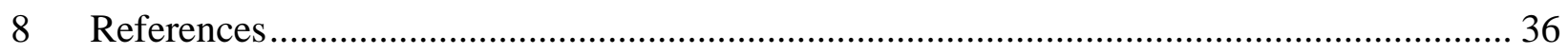

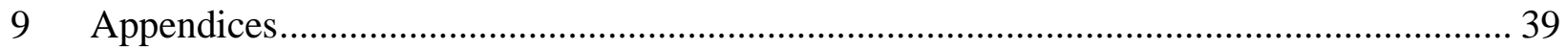

Appendix-1: Conceptual Rail Alignment - Horizontal and Vertical Plan Sheets ................... 39

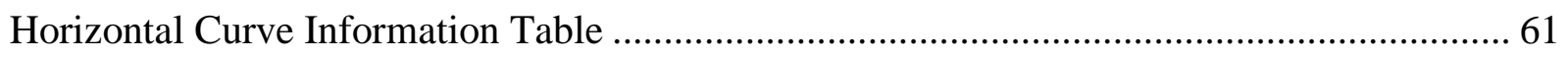

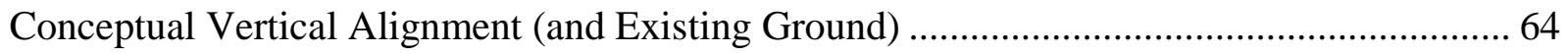

Appendix-2: Details of SimaPro Datasets for all primary processes used in Detailed LCA.... 79

Datasets of Processes under Infrastructure Construction.............................................. 79

Hot Mix Asphalt (HMA) Custom Dataset - Quantities and Calculations........................... 80

Road Reconstruction (Heavy) Process - Quantities and Calculations per mile .................. 81

Track Construction Process - Quantities and Calculations per mile................................. 82

Datasets for Processes under Rolling Stock Manufacturing ............................................ 83

Truck Manufacturing Process - Quantities and Calculations per Truck ............................ 84

Locomotive and Rail Car Manufacturing Process - Quantities and Calculations per unit ... 85

Datasets of Processes under Infrastructure Maintenance................................................ 85

Track Maintenance Process- Quantities and Calculation per mile .................................. 86

Datasets for Processes under Rolling Stock Maintenance ............................................... 86

Truck Maintenance Process - Quantities and Calculations per mile.................................. 87

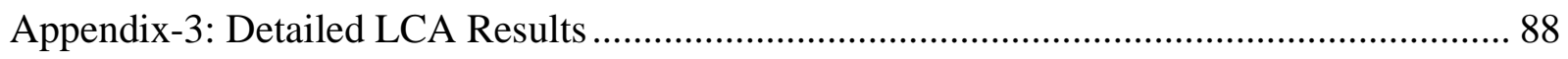

Greenhouse gas emissions summary of CR-550 route (in terms of $\mathrm{kg} \mathrm{CO}_{2}$ equivalents) .... 88

Greenhouse gas emissions Summary of CR-595 Route in terms of $\mathrm{Kg} \mathrm{CO}_{2}$ equivalents .... 89

Greenhouse gas emissions summary of Rail Route in terms of $\mathrm{Kg} \mathrm{CO}_{2}$ equivalents ........... 90

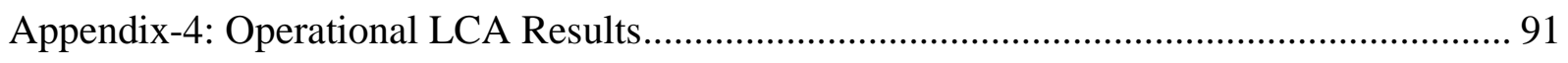




\section{List of Figures}

Figure 1: Eagle Mine. [10] ........................................................................................ 3

Figure 2: Concentrates Being Loaded into Railcars at the Humboldt Mill Facility. [13] ............. 4 Figure 3: Map of the Three Alternatives; CR-550 Route, CR-595 Route, and Conceptual Rail

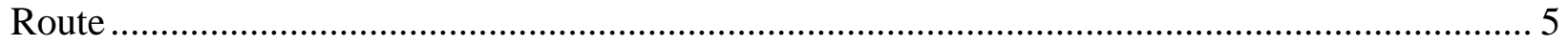

Table 1: Infrastructure and Operational Requirements......................................................... 6

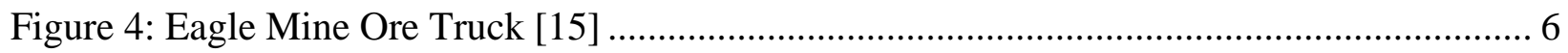

Figure 5: Hopper Car ..................................................................................................... 7

Table 2: Summary of the Geospatial Datasets Used in This Study .......................................... 9

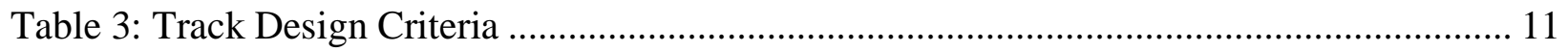

Table 4: Summary of Key Alignment Parameters .................................................................. 12

Figure 6: AC 4400 Locomotive (Source: [27])..................................................................... 13

Figure 7: Dispatch Statistics of Loaded Eagle Mine Train with a 4400HP Locomotive and 20 Rail

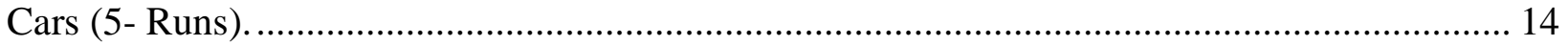

Figure 8: Train Performance Characteristics of Loaded Train Traveling from Eagle Mine to

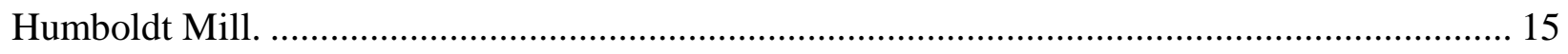

Table 5: Train Characteristics and Fuel Consumption. .......................................................... 16

Table 6: Additional Load Capacity (\# of railcars) Estimation by Trial and Error........................ 17

Table 7: Summary and Comparison of Detailed LCA and Operational LCA Methods.............. 21

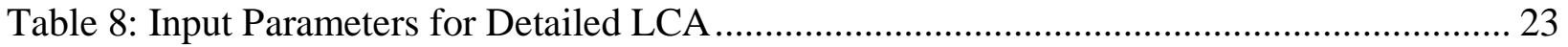

Figure 9: Phase-Wise Life Cycle Emissions Estimated Using Detailed LCA........................... 27

Figure 10: Greenhouse gas emissions of construction and maintenance phases of CR-595 route estimated using EcoInvent and custom datasets .............................................................. 28

Figure 11: Greenhouse gas emissions of construction and maintenance phases of rail route estimated using EcoInvent and custom datasets ............................................................... 28

Figure 12: Results of Operational LCA .............................................................................. 29

Table 9: Comparison of Results from Detailed LCA and Operational LCA (in Terms of $\mathrm{Kg} \mathrm{CO}_{2}$ Equivalents of Greenhouse Gas Emissions) ................................................................... 31

Figure 13: Comparison of Operation Phase Emissions Estimated by the Two Methods............. 32 


\section{List of Tables}

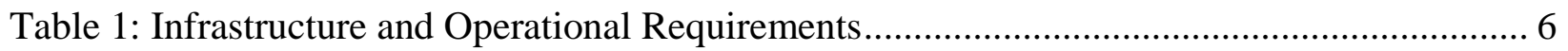

Table 2: Summary of the Geospatial Datasets Used in This Study ......................................... 9

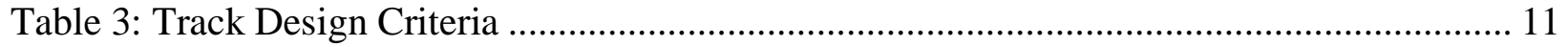

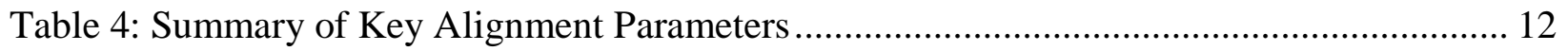

Table 5: Train Characteristics and Fuel Consumption. ....................................................... 16

Table 6: Additional Load Capacity (\# of railcars) Estimation by Trial and Error....................... 17

Table 7: Summary and Comparison of Detailed LCA and Operational LCA Methods............... 21

Table 8: Input Parameters for Detailed LCA ….................................................................... 23

Table 9: Comparison of Results from Detailed LCA and Operational LCA (in Terms of $\mathrm{Kg} \mathrm{CO}_{2}$

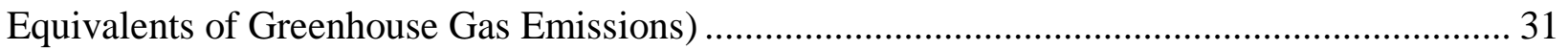




\section{Acknowledgements}

I would first like to express my sincere gratitude to my advisor, Dr. Pasi Lautala for his support and guidance without which this project would not have been possible. He has been a great source of motivation throughout the course of my time at Michigan Tech. Dr. Lautala has helped me with technical and academic aspects of the project with great patience. His innovative ideas and constant encouragement to improvise have been my driving force to achieve the project goals.

I would like to thank my committee members, Dr. David Shonnard and Dr. Robert Handler, for their guidance and assistance in completing this report. I would also like to thank Dr. Handler for his help with SimaPro software.

I acknowledge the work of Sumanth Kalluri (2016), which has been the basis for the Detailed LCA methodology used in this project. I am to truly grateful to Mr. Clint Jones of Mineral Range Railroad for his help and guidance for the rail route design, M.J.VanDamme Trucking for providing information about various aspects of the trucks used for transporting Eagle mine ore, and Mr. Joe Pertocik from Eagle mine for his valuable support in providing critical information about Eagle mine operations.

Finally, I am grateful to my family, friends and colleagues who have been encouraging and supportive all along.

This research was supported by National University Rail (NURail) Center, a US DOTOST Tier 1 University Transportation Center. 


\section{Abstract}

Transportation sector at large is a major consumer of fossil fuels and constitutes more than a quarter of the global greenhouse gas emissions. When making infrastructure route and mode choice decisions for new freight-oriented projects, it is important that environmental and emissions considerations are included as an integral part of the selection process. Emissions from freight transportation projects related to mining and natural resource industry are especially critical, as they involve high volumes and tonnages often in pristine environments. The most logical time for emissions analysis is during modal and route analysis that are often conducted in the planning stage of a project. One approach to perform such an analysis is Life Cycle Assessment (LCA); a method for estimating emissions, energy consumption and other environmental impacts of a project over its life cycle.

A major drawback of performing a detailed LCA comprising of all life cycle phases of a freight transportation project is that it requires extensive data, human effort and expertise. Availability of resources and data required for LCA often tends to be a challenge at this stage. This could be a discouraging factor for the stakeholders, resulting in simply neglecting this type of an evaluation. It is apparent from previous research that emissions from the "Operations" phase often account for a major portion of the overall impacts, so part of this research investigates whether a process that includes only the Operations phase emissions would still provide reliable outcomes.

This research builds on a detailed LCA comparison performed on a previous case study by Kalluri et al. (2016) and performs a comparative life cycle assessment of three different route alternatives for transporting copper/nickel ore from Eagle mine to Humboldt mill. The alternatives included the currently used highway route (CR-550), an alternative highway route (CR-595) considered in the planning stage of the mine, and a conceptual rail route designed as part of this study. This assessment was performed using two different methods; Detailed LCA and Operational LCA. The Detailed LCA incorporated the emissions arising from the complete life cycle of the transportation activity, including the construction operation and maintenance phases of both Infrastructure and equipment. This method used SimaPro version 8 software along with Ecoinvent v3.1 database and several other custom datasets created using regional and study specific data. The Operational LCA method considered only the emissions from the operations phase activities and the life cycle of the fuels used from well to wheel. This method used GREET 2016 model and the in-built database it offers, along with case specific data of fuel consumption and type of vehicles used.

The LCA was performed for the current expected mine life of 8 years and for 9, 10, 15, and 20-year mine lives, as the ongoing explorations at and around the mine location may offer potential for different mine life extensions. The results obtained in terms of $\mathrm{kg} \mathrm{CO}_{2}$ equivalents of GHG emissions show that, from an emissions perspective CR-595 is a better alternative between the two road options and the rail option is clearly the best among the three, especially for longer mine lives. In addition, there is a significant potential for the rail route to serve traffic from the local timber and forest products industries. However, the analysis also shows that there are significant uncertainties in the results, depending on the data used. 


\section{Introduction}

\subsection{Background}

Transportation is one of the biggest contributors of greenhouse gas emissions in the United States and across the globe. According to the United States Environmental Protection Agency (EPA) transportation accounted for about $26.3 \%$ of country's emissions in the year 2014 [1]. It is evident from past research that freight movements are responsible for a significant portion of all transportation emissions. In fact, a study conducted by Schipper et al. in 1996 suggests that energy use in freight transportation will surpass that of passenger travel by the year 2020 [2]. Freight intensive industries, such as natural resources industry, are especially demanding on transportation, as they often move high weights and operate in remote locations with marginal or non-existent infrastructure. The need for new transportation services (infrastructure/operations) introduces the challenge of selecting the best available modal/route alternative.

It is common for natural resource industries to consider several transportation alternatives and evaluate them in a great detail from an economics perspective. The simplest form of analysis is to compare the various capital and operation costs of each alternative, but methods such as life cycle cost analysis (LCCA), benefit cost analysis (BCA) and Economic Impact Analysis can also be used to incorporate the benefits in the analysis. Most projects also require completion of Environmental Impact Assessment (EIA) to evaluate various environmental, social, cultural and health impacts of the project and its alternatives. The methodology and different impacts considered in an EIA vary on a case to case basis, but there is an increasing interest toward using life cycle assessment (LCA) to estimate the comprehensive environmental impacts. LCA has been defined in several ways by agencies around the world. For instance, the United Nations Environment Program (UNEP) defines it as a tool for the systematic evaluation of the environmental aspects of a product or a service system through all stages of its life cycle [3]. Since its inception in the 1960s, LCA has been adopted by several industries, predominantly by manufacturing and energy industries.

While several studies have been conducted on performing LCA for transportation projects, they have rarely covered all the life cycle stages, i.e. construction, operations, maintenance, and end of life. A majority of the studies concentrated only on the operation phase (or tailpipe) emissions of vehicles, excluding the construction and maintenance phases. For example, the study by Steiner et al. 2015 evaluates and compares the carbon emissions from trucks and trains in the Midwestern and Northeastern United States between 1997 and 2007[4]. A few studies have incorporated all phases, like Facanha et al. 2007 who analyzed the life cycle air emissions factors of truck, rail and air transportation modes in detail by incorporating the construction, maintenance and operation phases of both infrastructure and equipment[5].

LCA methodologies tend to be resource demanding and data intensive. Since the main objective of performing transportation LCA during planning is to rank the different alternatives 
under consideration, it generally needs to be performed fairly early in the project. Due to early need for analysis, one of the major concerns is the availability of data and resources required to perform a detailed LCA. Several databases are available in the market, but they do not always cover all the processes and phases in a project. Moreover, some of the datasets they offer are not suitable for every geographic region. For example, in the study by Kalluri et al. 2016, custom datasets pertaining to several construction, operations and maintenance processes had to be created with regional and case specific data to perform an LCA [6]. It is evident that there is still room for research and improving the methodology and databases required for transportation LCA, at least to make the LCA process easier and more efficient.

\subsection{Study Objectives}

This research uses LCA to compare the transportation alternatives for the ore movements of Eagle mine (an operating nickel and copper mine in Michigan's Upper Peninsula) from carbon footprint perspective. The study does not comprehensively address all the greenhouse gases and other environmental impacts. As such, it can only be considered a partial LCA. The LCA is performed to evaluate two road alternatives and one rail alternative for Eagle mine ore movement. One of the road alternatives is currently used to transport the ore and the other one was considered during the Eagle mine development. The conceptual rail route was specifically designed for the purposes of this study. A secondary objective is to investigate the use of different tools to accomplish LCA. The study includes 1) a detailed LCA of all phases completed in SimaPro and 2) an LCA (later referred to as 'Operational LCA') that limits the analysis to operations phase emissions only, conducted in Greenhouse-gases Regulated Emissions and Energy use in Transportation model (GREET)[7]. The outcomes for operational phase are compared to evaluate whether there are any major differences between the methods.

\subsection{Report Structure}

This report will first introduce the Eagle mine case study and provide a more detailed description of the three alternative routes evaluated in the study. It will explain in detail the design procedure used for the conceptual rail route, discussing the data, software and design standards used. It will also discuss the methodology and software used to estimate the fuel consumption in the rail alternative. The LCA process will be introduced along with a brief literature review, and the methodologies of both approaches will be explained. The report will conclude with emissions results from the analysis, discussion of alternatives, study conclusions and recommendations for future research. A more detailed information on data used in the research is provided in Appendices. 


\section{Case Study}

\subsection{Eagle Mine}

Eagle mine (formerly known as Kennecott Eagle mine) is a high-grade nickel and copper mine located in Western Marquette County of the Upper Peninsula of Michigan. It is the only primary nickel mine in the United States[8]. The mineral deposit at Eagle mine is classified as a high-grade magmatic sulphide deposit rich in economic minerals pentlandite and chalcopyrite[9]. The deposit was first discovered in the explorations by the Rio Tinto group and later acquired by the current owner and operator, Lundin Mining Corporation. Eagle mine is expected to produce 182,500 US tons of nickel and 147,500 US tons of copper and minor quantities of other metals like cobalt, gold and platinum over an estimated mine life of eight years [8]. The mine became operational in the fourth quarter of 2014 and has been operating in full capacity since then. Figure 1 shows an aerial view of the Eagle mine.

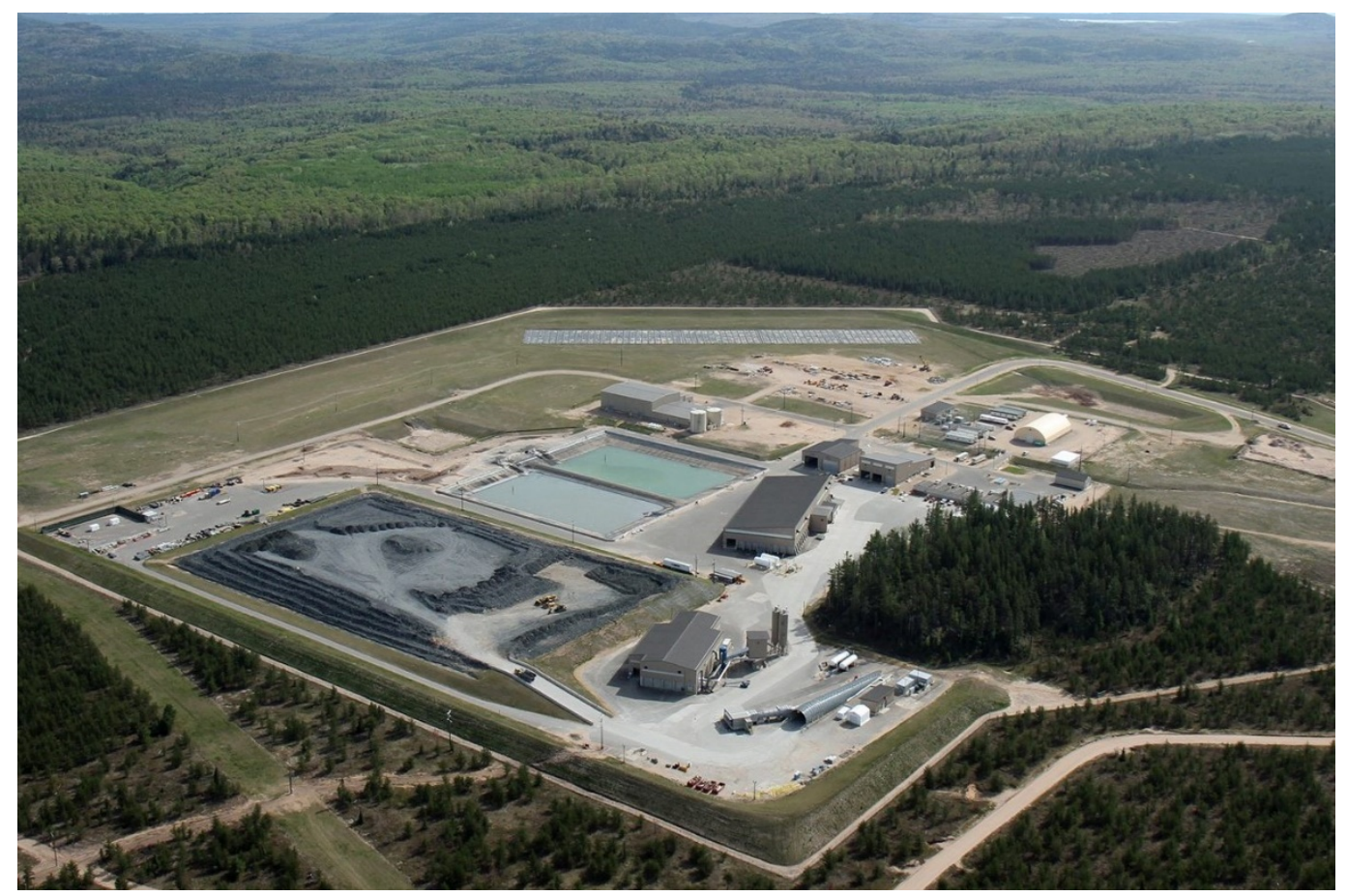

Figure 1: Eagle Mine. [10]

There has been active exploration for additional mineral resources around the mine location. In July 2014, Lundin announced the discovery of Eagle East mineralization, which is expected to yield an estimated 1.29 million tons of ore containing 5.2\% nickel and $4.2 \%$ copper, classified as 'indicated' grading and additional 0.29 million tons classified as 'inferred' grading and containing $1.7 \%$ of Nickel and $1.4 \%$ copper[11]. As a result, the company has announced the possibility to extend the mine operations by one year. As the exploration program continues, it is possible for more deposits to be found in and around the location, which may lead to further extension of mine life. 


\subsection{Humboldt Mill}

The mineral ore extracted at the mine is processed at the Humboldt mill to produce nickel and copper concentrates. The process uses conventional crushing, grinding and flotation methods. "Humboldt Mill is a historic brownfield site built by Cleveland Cliffs Iron Company in the 1950's" [9]. It was primarily used for milling iron ore until early 1980's after which it was used for various other purposes under several different ownerships. It was acquired in 2008 by Rio Tinto for Eagle mine operations and was sold to Lundin along with the mine[12]. The mill is currently operating at full capacity, processing approximately 2,000 metric tons (2,200 US tons) of ore per day. The metal concentrates produced at the Humboldt mill are currently being transported by rail to various customers within North America or for further shipment overseas. The mill was located near operational rail line and a 1.8-mile long spur line was constructed to establish direct connection to the mill. The concentrates are loaded into covered rail cars (hoppers) inside the Humboldt mill facility (Figure 2). The concentrate cars are moved from the mill by Mineral Range Railroad (MRR), a local shortline railroad service provider, and later interchanged to CN Railway at Ishpeming.

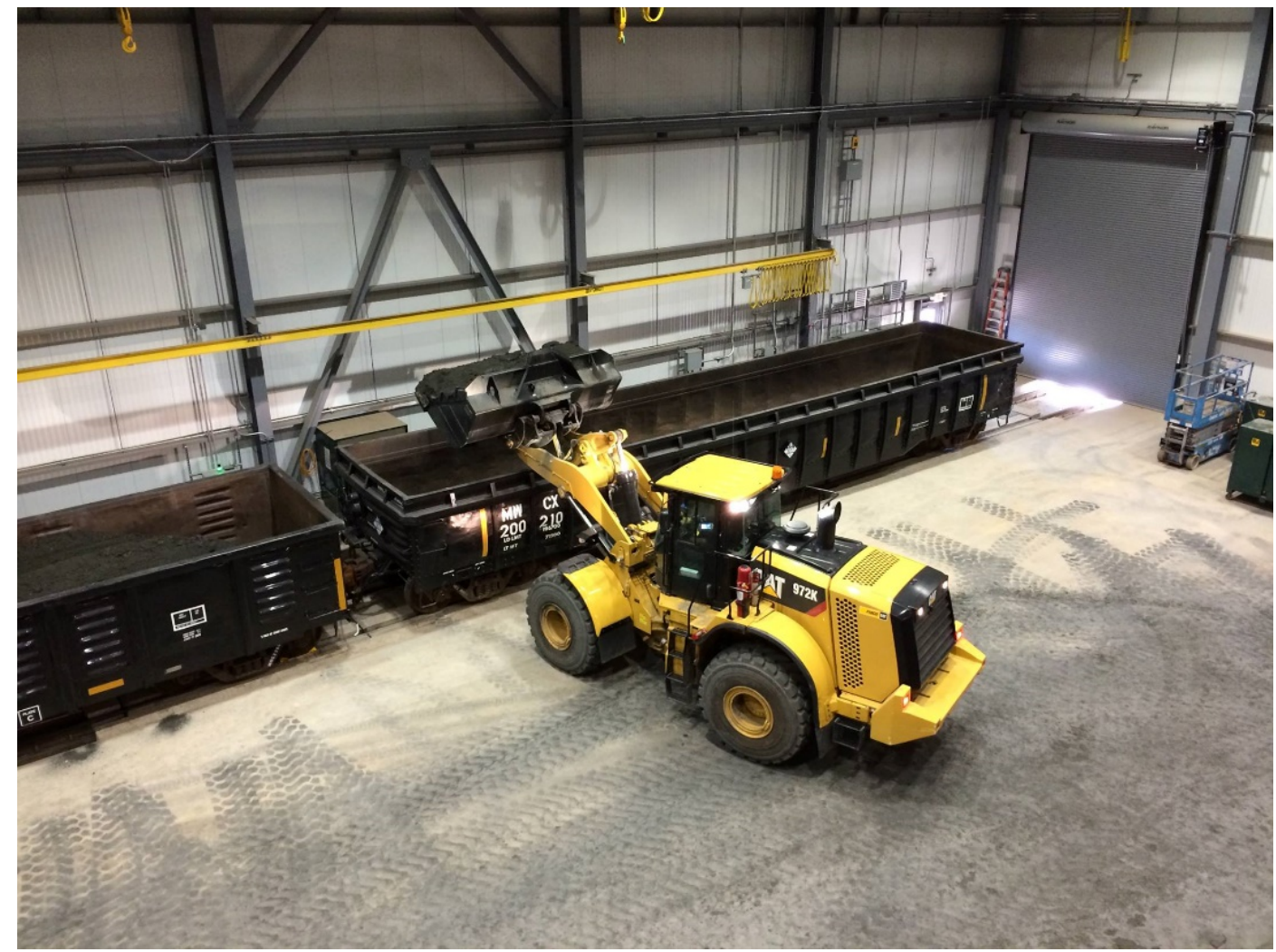

Figure 2: Concentrates Being Loaded into Railcars at the Humboldt Mill Facility. [13]

\subsection{Ore Transportation and Transportation Alternatives}

The primary focus of this study is the transportation of ore from Eagle mine to Humboldt mill. Three transportation alternatives, the CR-550 route, CR-595 route and the rail route, are investigated. The general location of the mine and these routes is presented in Figure 3 and the key 
infrastructure parameters for each route alternative are provided in Table 1. Each alternative is described in more detail in the following sections. The values for road infrastructure upgrades were developed based on data from Marquette County Road Commission [14]. Quantities for railway construction were developed as part of the design process. Table 1 also presents key equipment demands for operations. When moved by trucks, the daily ore demand translates to 44 truckloads per day. Each truck has 45 metric ton (49.6 US ton) capacity (Figure 4). If rail option was used, 20 'Hopper cars' (Figure 5) would be required per day, each with a capacity to hold 100 metric tons (110 US ton) of ore.

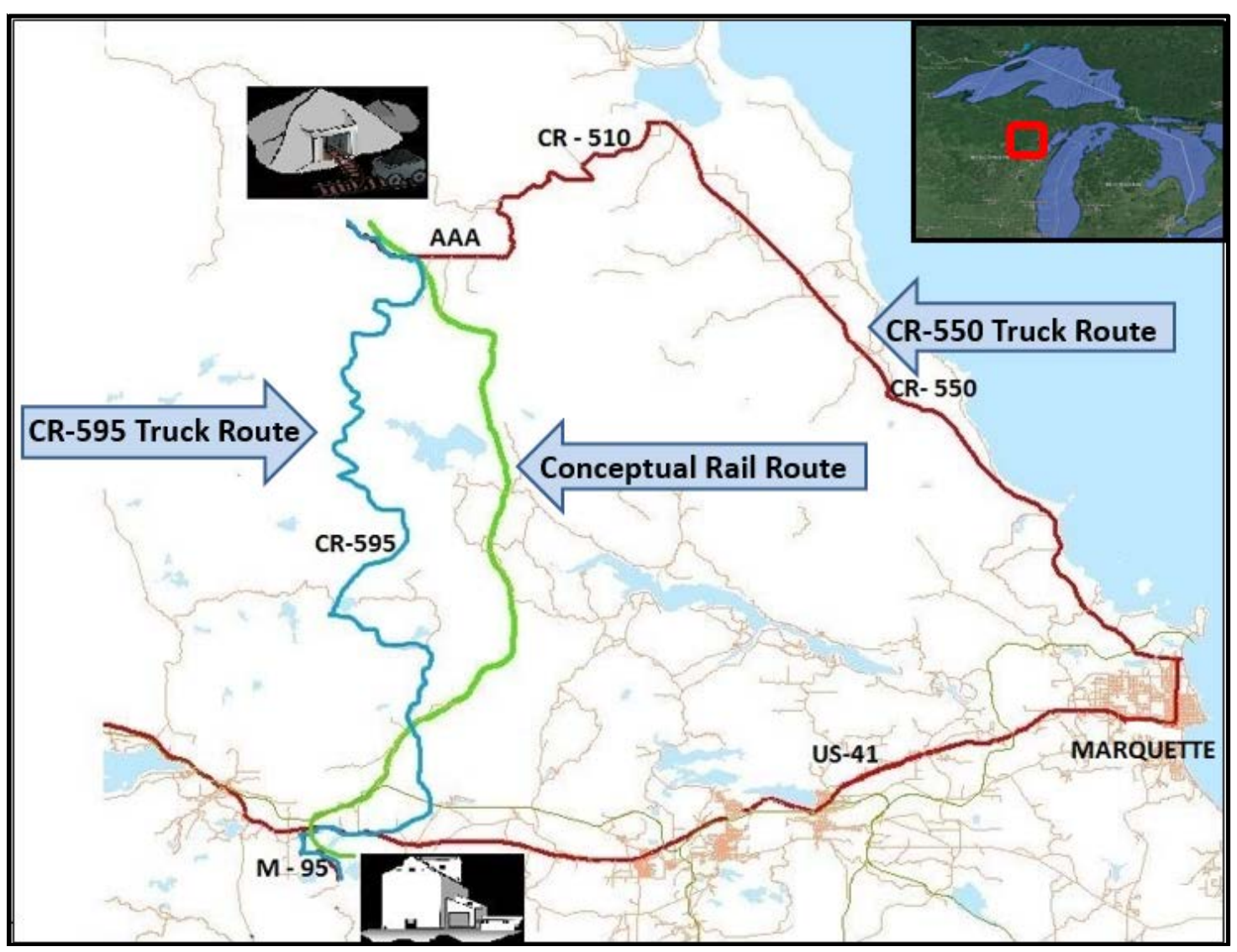

Figure 3: Map of the Three Alternatives; CR-550 Route, CR-595 Route, and Conceptual Rail Route 
Table 1: Infrastructure and Operational Requirements

\begin{tabular}{|l|l|l|l|}
\hline & CR-550 & CR-595 & Rail \\
\hline Total One-Way Distance (miles) & $\mathbf{6 5}$ & $\mathbf{2 4}$ & $\mathbf{2 4 . 6 6}$ \\
\hline $\begin{array}{l}\text { Heavy Reconstruction/ New } \\
\text { Construction (miles) }\end{array}$ & 14.4 & 22 & 21.06 \\
\hline Light Reconstruction (miles) & $\mathbf{1 2 . 1}$ & $\mathbf{0}$ & $\mathbf{0}$ \\
\hline No major upgrades (miles) & 38.5 & 2 & 0 \\
\hline Number of round trips per day & 44 & 44 & 1 (with 20 car train) \\
\hline Ore moved in each trip (US tons) & $49.6(\sim 50)$ & $49.6(\sim 50)$ & 2,200 \\
\hline $\begin{array}{l}\text { Total number of vehicles/ equipment } \\
\text { required for the operations }\end{array}$ & $\begin{array}{l}9(11 \text {-axle } \\
\text { Michigan } \\
\text { ore trucks) }\end{array}$ & $\begin{array}{l}\text { 4 (11-axle } \\
\text { Michigan } \\
\text { ore trucks) }\end{array}$ & $\begin{array}{l}20 \text { hopper cars and } \\
\text { one AC 4400 } \\
\text { locomotive }\end{array}$ \\
\hline
\end{tabular}

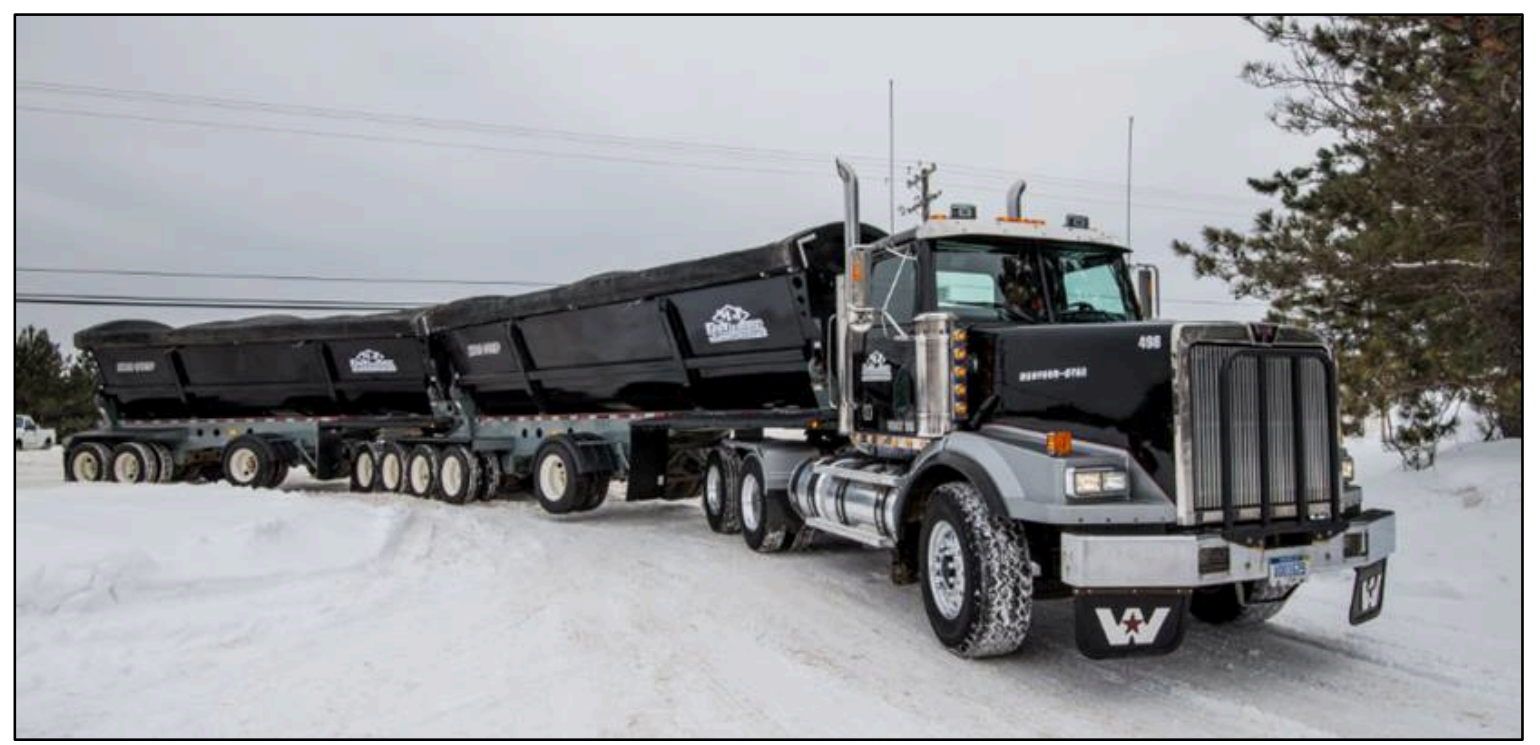

Figure 4: Eagle Mine Ore Truck [15] 


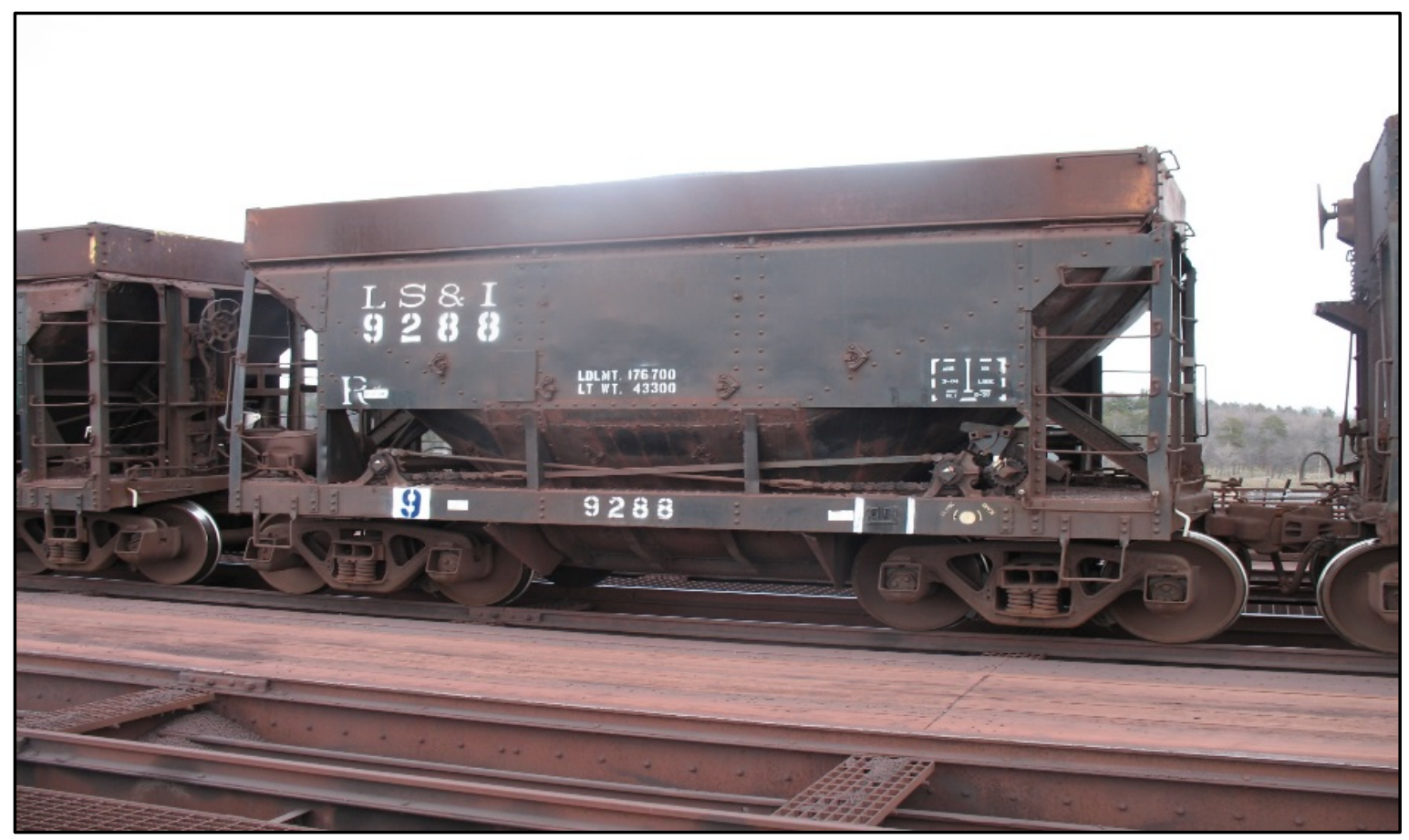

Figure 5: Hopper Car

\section{$2.1 \quad C R-550$ Route}

The 65-mile long route (CR-550 route) comprising of Triple-A road, County Roads 510, 550 and 601, US highway-41 and Michigan state highway-95 is the one currently used by Lundin to move the ore between the Eagle Mine and Humboldt Mill. The route passes through the city of Marquette that has a population of over 21,000, causing public concern about safety and congestion on the city roads[16]. Several sections of the County Roads 510, 550 and 601, and the Triple-A road had to be upgraded prior to the mining operations. No upgrades were required on the US highway 41. According to Marquette County Road Commission, there is no planned maintenance on these upgraded roads during their 20-year life (Iwanicki, 2015) [17]. However, snow removal has to be accounted for an estimated 136 days/year[17].

\subsection{CR-595 Route}

A 24-mile long CR-595 route was considered as an alternative in the planning stage of the mine. This route is comprised of Triple-A road, County roads 595 and 601, US highway 41 and Michigan state highway 95. This route required 21.5 mile construction of a new all-season primary county road (CR-595) running North-South to connect Triple-A road (also known as CR IAA) with US-41. For this route to be functional for year round operation, a 0.5-mile section of the existing Triple-A road also needed to be reconstructed to an all season standard. The Marquette County Road Commission (MCRC) applied for the necessary permits to construct the road in 2010, but the United States Environmental Protection Agency (US-EPA) objected the construction of this road citing concerns about wetlands impacts [18]. Consequently, the CR-550 route was chosen to transport the ore and CR-595 was left undeveloped. This route hereafter will be referred to as 
"CR-595" route. The maintenance requirements for this route are similar to those of CR-550, but the fuel consumption and equipment requirements for snow removal differ due to the route length.

\subsection{Rail Route}

A new conceptual rail alignment was designed as part of this study and compared with the two road alternatives to transport ore between the mine and the mill. According to the local rail operator, Mineral Range Railroad [19], construction of a track between the mine and the CN mainline was briefly considered as an option during the planning stages. Basic information and guidance provided by Mr. Jones was used for the design. The main objective of the route design was to avoid wetlands and steep grades to the extent possible. Another consideration was emphasizing the use commercial forest lands for the route, both to be able to serve the prevalent timber industry in the area and to avoid private land acquisitions. Other potentially important aspects of land ownership, permitting, access and cost of construction were not taken into consideration. A more detailed design procedure is discussed later in the next section. 


\section{Rail Alternative}

The design procedure of rail alignment was broken down into two stages. The first stage concentrated on the terrain and other major topological factors such as wetlands, water bodies, and roads that would have the greatest impacts on the rail route. The second stage used the information to design preliminary horizontal and vertical alignments. The following sections explain the two stages in further detail.

\subsection{Stage 1: Conceptual Rail Route Constraints}

ArcMap was used to map identify the critical constraints along the potential route. Six primary datasets were used in this project and are summarized in Table 2. The data had different coordinate systems, both projected and geographic in nature and had to be converted into a single system, (NAD_1983_UTM_Zone_16N), using the project tool in ArcMap. These datasets were used to create reference data layers corresponding to contours, wetlands, roads and railroads in the study area. The layers were later converted to suitable formats and exported to Bentley Microstation for horizontal and vertical rail alignment design.

Table 2: Summary of the Geospatial Datasets Used in This Study

\begin{tabular}{|c|c|c|c|}
\hline SL \# & Name of Dataset & Metadata & Comments \\
\hline 1. & $\begin{array}{l}\text { Digital Elevation Model } \\
\text { of Marquette County(10 } \\
\text { meter DEM) }\end{array}$ & $\begin{array}{l}\text { Source: United States Geological Survey } \\
\text { (USGS) [20] } \\
\text { Type: Raster (Images) } \\
\text { Geographic Coordinate System: } \\
\text { GCS_North_American_1983 (NAD 1983) }\end{array}$ & $\begin{array}{l}\text { A raster dataset which } \\
\text { contains elevation data. It } \\
\text { was used to create } \\
\text { Hillshades and Contour } \\
\text { layers for elevation reference } \\
\text { in the alignment design. }\end{array}$ \\
\hline 2. & Michigan Roads & $\begin{array}{l}\text { Source: Michigan Geographic Data Library } \\
\text { Type: Vector (Shapefile) [21] } \\
\text { Projected Coordinate System: } \\
\text { NAD_1983_Hotine_Oblique_Mercator_Azi } \\
\text { muth_Natural_Origin }\end{array}$ & $\begin{array}{l}\text { A vector dataset in shapefile } \\
\text { format containing the data } \\
\text { about all roads in Michigan. } \\
\text { This layer trimmed to } \\
\text { Marquette county (study } \\
\text { area) and exported to } \\
\text { Microstation as a } \\
\text { Microstation drawing file. }\end{array}$ \\
\hline 3. & Michigan Railroads & $\begin{array}{l}\text { Source: Michigan Geographic Data Library } \\
\text { (USGS) [22] } \\
\text { Type: Vector (Shapefile) } \\
\text { Projected Coordinate System: } \\
\text { NAD_1983_Hotine_Oblique_Mercator_Azi } \\
\text { muth_Natural_Origin }\end{array}$ & $\begin{array}{l}\text { A vector dataset in shapefile } \\
\text { format containing the data } \\
\text { about all railroads in } \\
\text { Michigan. This layer } \\
\text { trimmed to Marquette } \\
\text { county (study area) and } \\
\text { exported to Microstation as a } \\
\text { Microstation drawing file. }\end{array}$ \\
\hline 4. & $\begin{array}{l}\text { National Boundary } \\
\text { Dataset (Michigan) }\end{array}$ & $\begin{array}{l}\text { Source: United States Geological Survey } \\
\text { (USGS) [23] }\end{array}$ & $\begin{array}{l}\text { A shapefile consisting of } \\
\text { county and city boundaries }\end{array}$ \\
\hline
\end{tabular}




\begin{tabular}{|c|c|c|c|}
\hline & & $\begin{array}{l}\text { Type: Vector (Shapefile) } \\
\text { Projected Coordinate System: } \\
\text { NAD_1983_UTM_Zone_16N }\end{array}$ & $\begin{array}{l}\text { in Michigan and was used as } \\
\text { a reference layer to trim } \\
\text { other layers to the study area. }\end{array}$ \\
\hline 5. & $\begin{array}{l}\text { National Hydrography } \\
\text { Dataset (NHD-Michigan) }\end{array}$ & $\begin{array}{l}\text { Source: National Wetlands Inventory by } \\
\text { U.S.F.W.S. [24] } \\
\text { Type: Vector (Geodatabase) } \\
\text { Geographic Coordinate System: } \\
\text { GCS_North_American_1983 (NAD 1983) }\end{array}$ & $\begin{array}{l}\text { This vector dataset is in the } \\
\text { format of a geodatabase and } \\
\text { contains the details of all } \\
\text { waterbodies in Michigan } \\
\text { including rivers, streams, } \\
\text { lakes, ponds etc. }\end{array}$ \\
\hline 6. & $\begin{array}{l}\text { Michigan Wetlands } \\
\text { Geodatabase }\end{array}$ & $\begin{array}{l}\text { Source: United States Geological Survey } \\
\text { (USGS)[23] } \\
\text { Type: Vector (geodatabase) } \\
\text { Projected Coordinate System: } \\
\text { NAD_1983_Albers }\end{array}$ & $\begin{array}{l}\text { This vector dataset is in the } \\
\text { format of a geodatabase and } \\
\text { contains the details of all } \\
\text { wetlands in Michigan }\end{array}$ \\
\hline 7. & $\begin{array}{l}\text { Michigan Commercial } \\
\text { Forest Act Lands }\end{array}$ & $\begin{array}{l}\text { Source: Michigan Department of Natural } \\
\text { Resources (MDNR) } \\
\text { Type: Vector (Shapefile) } \\
\text { Projected Coordinate System: } \\
\text { GCS_WGS_1984 }\end{array}$ & $\begin{array}{l}\text { A shapefile consisting of } \\
\text { spatial Information } \\
\text { pertaining to commercial } \\
\text { forest lands in the state of } \\
\text { Michigan. It was used in } \\
\text { generating alignment maps } \\
\text { and understanding land use } \\
\text { along the route. }\end{array}$ \\
\hline
\end{tabular}

\subsection{Stage 2: Alignment Design}

The main purpose of the conceptual alignment design was to enable the completion of LCA on a rail transportation alternative between the Eagle mine and the Humboldt mill by establishing sufficient route detail for estimating the emission from construction, operations and maintenance activities, if rail was used for ore movements. The designed rail alignment connects the Mineral Range Railroad tracks near Humboldt Mill with the mine site. The design was done using Power Geopak V8i software and with the support of the reference layers generated using ArcMap: 5-feet contours layer, roads, railroads and wetlands data layers corresponding to Marquette County. It was designed as a single track industry lead track with no intermediate sidings along the route. The design used the standard specifications prescribed by CSX Transportation in their Industry Sidetrack manual[25]. Although all railroad companies have their own standards/guidelines for track design, it is believed that using standards from a different company would only cause minor modifications in the conceptual alignment design. The details of key standards and specifications used in this design are provided in Table 3. 
Table 3: Track Design Criteria

\begin{tabular}{|l|l|l|}
\hline SL \# & Description & Standard \\
\hline $\mathbf{1 .}$ & Track Classification & $\begin{array}{l}\text { Industry Lead Track } \\
25 \mathrm{mph}\end{array}$ \\
\hline $\mathbf{2 .}$ & Design Speed & 10 degrees \\
\hline 3. & Maximum Degree of Curvature & 573.69 feet \\
\hline $\mathbf{4 .}$ & Minimum Curve Radius & 100 feet \\
\hline $\mathbf{5 .}$ & $\begin{array}{l}\text { Minimum Tangent Between } \\
\text { Horizontal Reverse Curves }\end{array}$ & $2.5 \%$ \\
\hline 6. & Maximum Grade $\quad \begin{array}{l}\text { Minimum Length of Vertical } \\
\text { Curve feet }\end{array}$ \\
\hline 7. & & \\
\hline
\end{tabular}

Although the undulating nature of the terrain in the study area made it challenging to avoid significant grades, the primary focus was to design an alignment that follows the existing contours as closely as possible while remaining within the maximum gradient limits. Another priority was minimizing the impact on wetlands. Factors such as land use, ownership or the actual constructability of the track received limited attention during the design process. Table 4 summarizes the key characteristics of the developed alignment. The horizontal alignment and vertical profile drawings corresponding to the design are provided in Appendix- 1.

From operational perspective, the 2,000 metric tons of ore that Eagle mine produces every day equal 20 car loads, if 100 ton capacity Hopper cars were used. It was assumed that these 20 cars are to be moved in a single daily train. The train length was considered in the vertical alignment design. More specifically, multiple vertical curves were avoided within a train's length to ensure smooth and safe operation of trains. 
Table 4: Summary of Key Alignment Parameters

\begin{tabular}{|c|c|c|}
\hline SL \# & Parameter & Value \\
\hline 1. & $\begin{array}{l}\text { Max gradient used along the } \\
\text { route }\end{array}$ & $1.5 \%$ \\
\hline 2. & Number of curves along the route & 63 curves \\
\hline 3. & Range of curvature & $4^{0}-8^{0}$ \\
\hline 4. & $\begin{array}{l}\text { Percentage of route miles in } \\
\text { curves }\end{array}$ & $23.5 \%$ (4.97 miles) \\
\hline 5. & $\begin{array}{l}\text { Approximate Percentage of route } \\
\text { miles on wetlands }\end{array}$ & $3.5 \%$ (0.75 miles) \\
\hline 6. & $\begin{array}{l}\text { Approximate Percentage of route } \\
\text { miles on commercial forest lands }\end{array}$ & $91.5 \%$ (19.25 miles) \\
\hline 7. & Number of river/stream crossings & 18 \\
\hline 8. & Number of grade crossings & 9 \\
\hline
\end{tabular}

\subsection{Operational and Motive Power Considerations}

The locomotive fuel consumption was estimated through a simulation that used Rail Traffic Controller (RTC). RTC is a windows-based software developed by Berkeley Simulation Software LLC that simulates movement of trains through rail networks [26]. The simulation requires recreating the actual vertical profile of the track. The software also requires train data such as type/model and number of locomotives, number of loaded and empty rail cars in the train, length and weight of rail cars etc. The locomotives were selected based on the assumption that each train would consist of 20 hopper cars of 100 metric ton load capacity. Since Mineral Range Railroad, the current service provider for Lundin has GP-38-2 locomotives, those were initially used in simulations. After it was recognized that single GP-38-2 wouldn't be capable of hauling the load, the simulation was rerun with AC 4400 locomotive (Figure 6). 


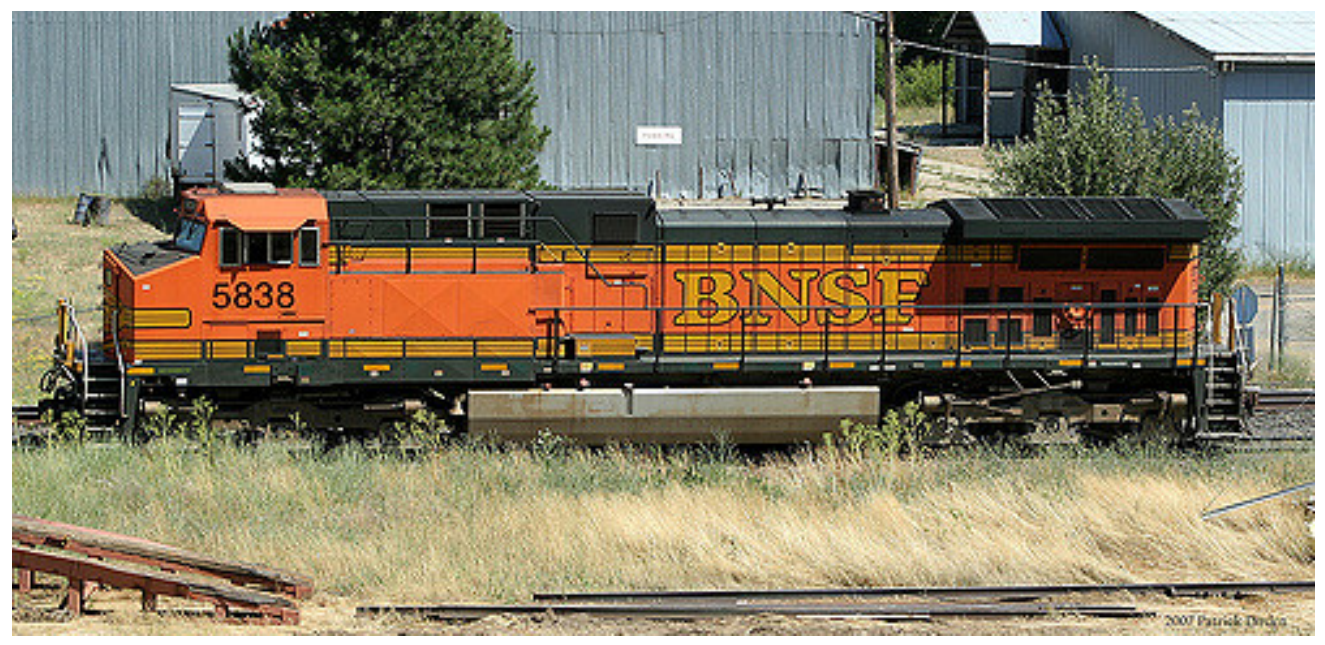

Figure 6: AC 4400 Locomotive [27]

\subsection{RTC Simulation and Train Characteristics}

Actual train configurations and weights were determined for the simulations in RTC and the trains were assumed to operate at maximum speed of $25 \mathrm{mph}$. The trains operated in loaded condition from the mine to processing plant and empty in the return. The simulation results were obtained in two steps; the Dispatch statistics and Train performance characteristics (TPC). The dispatch statistics window shows details of timetable, trip duration and fuel consumption. Figure 7 shows the dispatch statistics window of loaded train condition with an AC4400 Locomotive. The table reveals that the time on route for the loaded train is 60 minutes at the average speed of just below $21 \mathrm{mph}$. For the empty trains, the corresponding values were 53 minutes at average speed of over $23 \mathrm{mph}$. If the loaded and empty cars were ready to go on each end of the route, the time suggests that a round trip could be completed well within the 12 hour operational window by the train crew. The TPC window gives a graphical representation of various performance characteristics of a train such as, speed, throttle, dynamic brake, air brake, elevation data of the track, time, distance and train characteristics. Figure 8 shows the TPC window of the same run. The TPC window illustrates characteristics including train speed, throttle/brake and track elevation with respect to train location along track. (In the same order from top to bottom). Two locomotives (AC4400 and GP-38-2) were tested in combination with a 20 railcar train, and the most fuel efficient alternative was selected for the LCA analysis. Table 5 gives the details of important train characteristics and fuel consumption data pertaining to the two locomotive alternatives. 


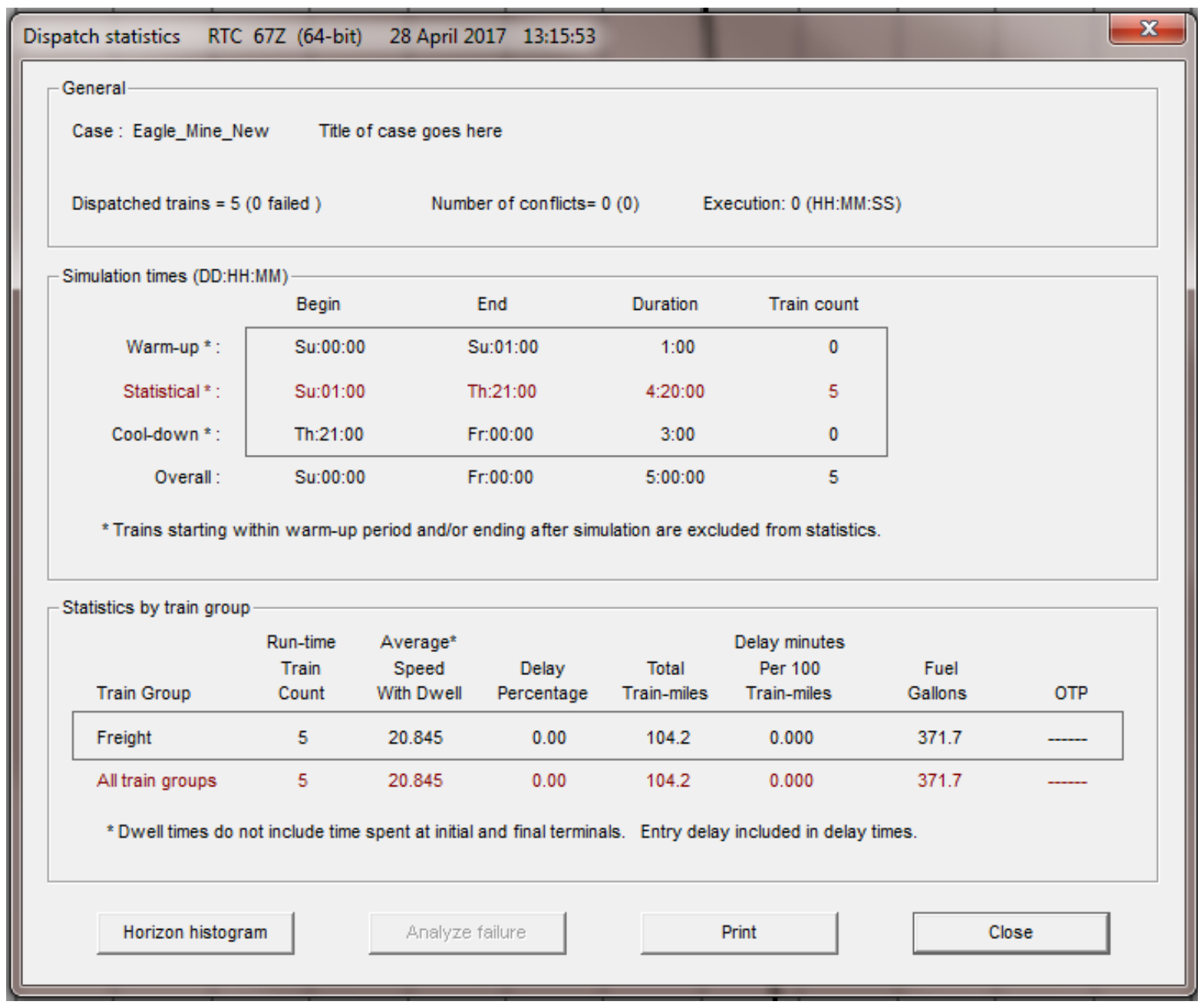

Figure 7: Dispatch Statistics of Loaded Eagle Mine Train with a 4400HP Locomotive and 20 Rail Cars (5-Runs). 


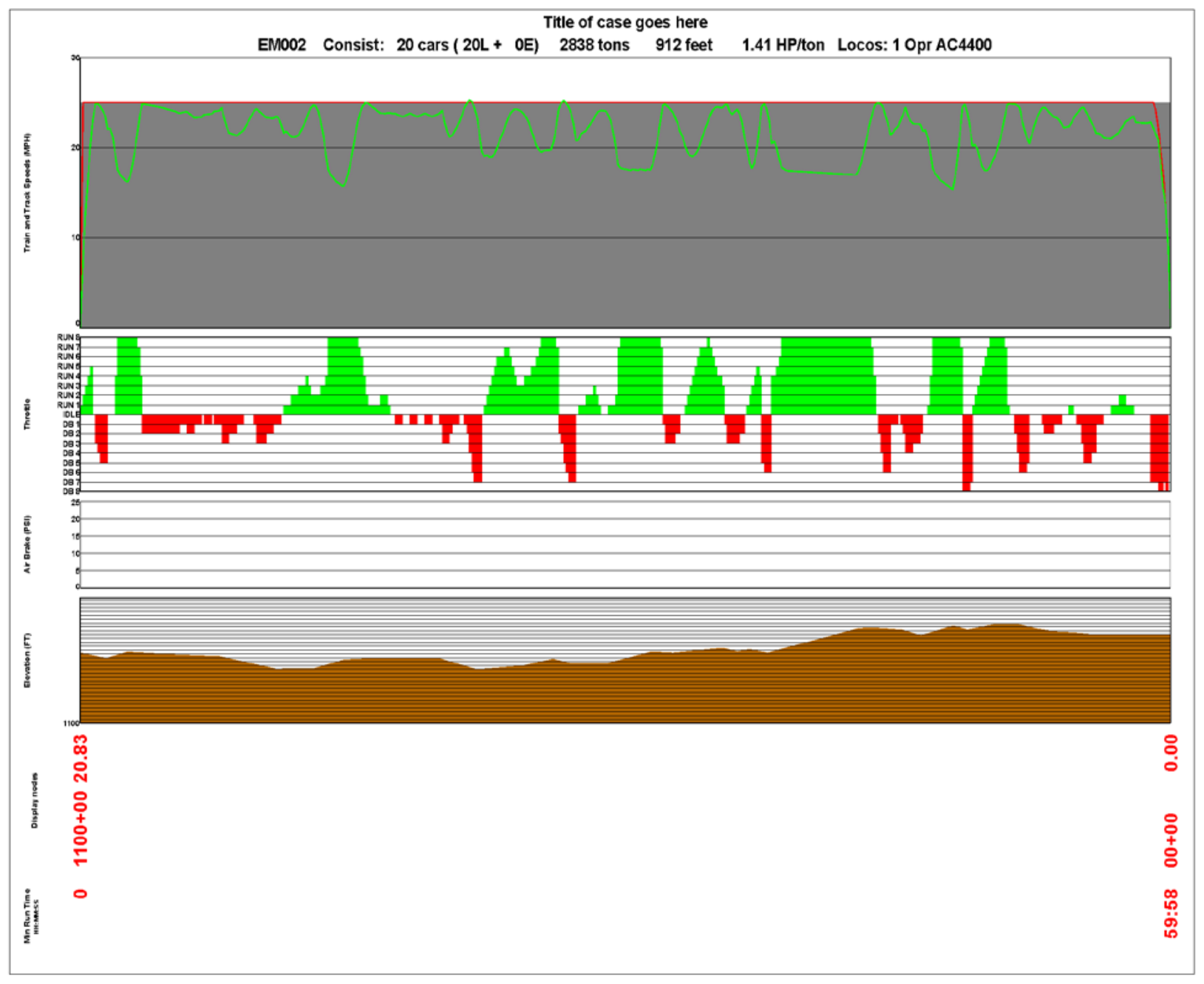

Case: Eagle_Mine_New RTC run: 28 April 2017 13:17:45 User: Hamed Pouryousef of Michigan Technical University

Figure 8: Train Performance Characteristics of Loaded Train Traveling from Eagle Mine to Humboldt Mill. 
Table 5: Train Characteristics and Fuel Consumption.

\begin{tabular}{|l|l|l|l|}
\hline SL \# & Characteristic & Option 1 & Option 2 \\
\hline $\mathbf{1 .}$ & Locomotive & GP-38-2 (2000 HP) & AC 4400 (4400 HP) \\
\hline $\mathbf{2 .}$ & Number of Locomotives & 2 & 1 \\
\hline $\mathbf{3 .}$ & Number of Rail cars & 20 & 20 \\
\hline $\mathbf{4 .}$ & Power/Weight ratio - loaded & $1.45 \mathrm{HP} /$ ton & $1.41 \mathrm{HP} /$ ton \\
\hline $\mathbf{5 .}$ & Fuel Consumption - Loaded & 105.84 gal & 74.34 gal \\
\hline $\mathbf{6 .}$ & Fuel Consumption - Empty & 32.2 gal & 12.9 gal \\
\hline 7. & Total (one round-trip) & 138.04 gal & 87.24 gal \\
\hline
\end{tabular}

\subsection{Additional Load Carrying Capacity}

As the majority of the new rail alignment passes through commercial forest area and the region is known for its logging activities, for a potential additional benefit of the rail route would be serving the timber and forest products industry in the region. To calculate the actual length of the alignment passing through commercial forest land a GIS dataset of "Michigan Commercial Forest Act Lands” published by Michigan Department of Natural Resources[28] was acquired and the rail alignment was overlaid on it. It was found that 19.25 miles out of the 21.06 mile long track lies in commercial forests. These areas are highlighted in the horizontal alignment designs provided in Appendix 1.

The logging companies operating in this area currently move their produce via trucks. These companies might benefit from the new rail infrastructure while reducing emissions caused by trucking operations. However, the daily volumes of logs tend to be small and operating a train exclusively for log movements may not be financially feasible. On the other hand, the AC 4400 locomotive (or two GP-38s) chosen for the analysis would not use their maximum hauling capacity with 20 carloads of ore. Hence, RTC was used to iteratively estimate the maximum load and number of rail cars without adding another locomotive. This was done by running RTC simulations with gradually increasing the number of loaded railcars in the train until the train stalled (exceeded the capacity of the locomotive). Table-6 shows the details of the simulation results.

It was found that 23 additional fully loaded railcars, each with a 100 ton payload capacity can be added to the train without exceeding the maximum hauling limit. However, it is not recommended to load the train to its full capacity. For 43 loaded cars, the power to weight ratio $(\mathrm{P} / \mathrm{W})$ at this level of loading would be as low as $0.68 \mathrm{HP} /$ ton and a minor change or overloading in train composition could lead to stalling of the train mid-route. It is recommended that loading is limited to 35-40 cars in order to maintain the P/W close to $0.8 \mathrm{HP} / \mathrm{ton}$. Based on the number of cars added and the location where they are added to the train, there would be an increase fuel 
consumption and also the maintenance requirements of the track and equipment. However, these additional costs can be assumed to be exceeded through the increased revenue from log movements.

Table 6: Additional Load Capacity (\# of railcars) Estimation by Trial and Error

\begin{tabular}{|l|l|l|l|l|l|}
\hline SL\# & $\begin{array}{l}\text { \# of } \\
\text { Railcars }\end{array}$ & $\begin{array}{l}\text { Train Length } \\
\text { (Feet) }\end{array}$ & $\begin{array}{l}\text { Total Weight } \\
\text { (Tons) }\end{array}$ & $\begin{array}{l}\text { Power/Weight } \\
\text { (HP/Ton) }\end{array}$ & $\begin{array}{l}\text { Fuel } \\
\text { Consumption } \\
\text { (Gallons) }\end{array}$ \\
\hline $\mathbf{1 .}$ & 20 & 912 & 2838 & 1.41 & 74.34 \\
\hline $\mathbf{2 .}$ & 25 & 1122 & 3496 & 1.14 & 93.52 \\
\hline $\mathbf{3 .}$ & 30 & 1552 & 4153 & 0.96 & 113.24 \\
\hline $\mathbf{4 .}$ & 40 & 1752 & 5468 & 0.73 & 137.64 \\
\hline $\mathbf{5 .}$ & 43 & 1880 & 5863 & 0.68 & 149.5 \\
\hline $\mathbf{6 .}$ & 44 & 1923 & 5994 & 0.67 & - ( Stalled) \\
\hline
\end{tabular}




\section{Life Cycle Assessment}

\subsection{Background}

Life Cycle Assessment (LCA) is a method to understand and quantify the environmental impacts of a process or a product over its life. The concept of LCA was introduced in the 1960's due to limitations of raw materials and energy resources. Initially, the focus was on reducing energy \& natural resource consumption and air \& water pollution. However, over the years, it has evolved to include several aspects like global warming, ozone layer depletion, impacts of solid and hazardous wastes[29]. LCA has slowly gained popularity, primarily in energy and manufacturing industries. As product manufacturers began to use LCAs to make broad marketing claims, concerns over inappropriate use emerged, as there was no uniform methodology or global standards. This led to the development of LCA standards by the International Organization for Standardization (ISO), the ISO 14000 series[29]. ISO 14040 is the standard that describes the principles and framework for performing LCA and was last revised in the year 2006. The LCA in this study was performed according to the ISO 14040:2006 framework[30].

\subsection{Literature Review of Life Cycle Assessment in Transportation}

Transportation activities around the world are rapidly increasing every year and so are the concerns about its environmental impacts. A study published by Eom, Schipper and Thompson in 2012 has discussed the global trends in freight $\mathrm{CO}_{2}$ emissions[31]. It studied the eleven member countries of the International Energy Agency (IEA) between the period of 2007 - 2010 and the emissions pertaining to freight transportation are increasing heavily, with the exception of Japan. The study also claims that there has been a continued increase in the share of trucking in the overall freight activity contributing significantly to the emissions, and recommends a modal shift towards rail [31].

Over the past decade, the use of LCA in transportation industry and an academic focus and research in this area have increased. Several methodologies and frameworks for performing transportation LCA have been proposed. However, most of them have concentrated on road transportation and only a few studies involved other modes. Further, majority of this research has concentrated on the impacts of operations phase i.e. tailpipe emissions and fuel life cycles. Few studies have incorporated the construction and maintenance impacts of infrastructure or vehicle and other equipment. One of the first studies to incorporate all the life cycle stages in a freight transportation LCA was published in 2007 by Facanha and Hovarth [5]. This study compared the emissions from road, rail and air modes for transporting freight in the continental United States. They performed LCA on production, maintenance, use and end of life phases of both infrastructure and vehicles, along with the life cycle of fuels consumed and found that the total life cycle emissions are significantly underestimated, if only tailpipe emissions are considered (by up to 38\% in case $\mathrm{CO}_{2}$ and $\mathrm{NO}_{x}$, and up to $700 \%$ in case of $\mathrm{CO}$ and $\mathrm{SO}_{2}$ ). 
In 2011, Szoege conducted an LCA analysis to compare various environmental impacts of freight transportation via rail and road covering the whole life cycle[32]. This analysis was conducted in SimaPro version 7.1 using Inventory and datasets composed at ETH Zurich with data specific to Switzerland. Based on the case study he concluded that the environmental impact of road transport is 7.3 times greater than that of rail transport. Marheineke performed a similar LCA study in Germany, but unlike the typical process flow analysis LCA, he proposed a hybrid model of Input-Output analysis which would help in checking the accuracy of an existing process chain and deciding if it should be more detailed [33].

\subsubsection{LCA Databases and Tools}

Besides the framework and methodology, reliable datasets and life cycle inventories are critical for an LCA. The life cycle of a product or a process involves a number of steps, materials, sub processes and flows which in turn have their own upstream processes and flows to the extent defined in the scope and system boundary of an LCA. There are several databases providing life cycle inventories for areas including energy, manufacturing processes, materials, waste treatment, etc. Some of the most commonly used databases are the Ecoinvent, US Life Cycle Inventory, and $\mathrm{GaBi}$ database. Many of these databases are continuously developed and updated with the most current data. EcoInvent provides a life cycle inventory for transportation services. In 2004, Spielmann and Scholz developed the EcoInvent life cycle inventory for transporting goods by road, rail, and water by using some of the comprehensive European inventories established in late 1990s [34]. EcoInvent database is used in the Detailed LCA performed in this study, but it is also complemented by a custom dataset developed by the researchers.

There are also several LCA tools and software available in the market. Some of these tools have built in databases and some support the use of other available databases. OpenLCA, GaBi, SimaPro, and the GREET model are a few common LCA tools. They mainly differ in the type of interface and constitute different impact assessment methods. SimaPro was developed by Pre Sustainability and is used worldwide by several educational institutions and businesses. It can use different databases available in market and also provides the tools to develop custom datasets. The Greenhouse gases, Regulated Emissions, and Energy Use in Transportation (GREET) model, on the other hand, is a tool developed by Argonne National Laboratories for estimating greenhouse gas emissions from the transportation fuel and vehicle life cycles[7]. Its use has been predominantly limited to passenger and transit oriented projects, but is slowly expanding to freight transportation as well. For instance, Winbrake et al. developed a tool called Geospatial Intermodal Freight Transport (GIFT) to characterize and evaluate environmental impacts of shipping decisions in the Great Lakes region of US and used GREET to determine the emissions factors for truck and rail modes[35]. In this study, GREET 2016 model and its basic parameters, such as distance and vehicle type, is used for the operational LCA analysis.

In 2016, a comparative LCA was conducted by Kalluri et al. of Michigan Technological University to evaluate several road, rail and multimodal alternatives for transporting ore and concentrates for a planned Copperwood copper mine in Michigan, USA [36]. They used Simapro 
software to calculate the emissions occurring from all life cycle stages including construction, maintenance and operation of infrastructure and equipment. The study used the Ecoinvent database as a foundation, but regional data was collected to the extent available from project stakeholders and industry experts to replace some of the Evoinvent values that are mainly developed for European environment. In his study, Kalluri found that while the operation phase is responsible for the majority of the overall emissions, the construction phase was also a significant contributor for the alternatives that needed new infrastructure, especially when the expected mine life was fairly short[6]. This research builds on the methodology proposed by Kalluri et al. and uses some of the regional datasets created in that study, since the case study used in this research pertains to the same geographic region.

\subsection{Detailed LCA and Operational LCA}

Performing Life Cycle Assessment of transportation systems is inherently a time and data intensive process. If all life cycle phases are to be incorporated, it involves numerous processes pertaining to construction, operations and maintenance activities. Data on the different material and energy flows of each process needs to be acquired and the relationship between them need to be understood. Not all processes involved in a project have readily available datasets in the standard databases and some available datasets need to be updated with regional and case specific data for reliable results. In addition, performing an LCA requires sufficient understanding of the concept itself and expertize in using LCA software.

The challenges above pose a concern when using LCA as part of mode/route analysis in freight infrastructure projects. Since the main objective of performing LCA is to rank the different alternatives under consideration, it generally needs to be performed early in the planning stage of a project. One of the major concerns is the availability of data and resources that are required to perform a "detailed LCA". Even though understanding the overall life cycle emissions is important, performing a detailed LCA at such early projects stage may be considered unfeasible or too resource intensive by the stakeholders. Hence, there would be a benefit, if the time, effort and resources required to perform an LCA in such projects could be reduced.

As mentioned, this research builds on such detailed comparative LCA process developed by Kalluri et al. (2016)[6] and applies it to the Eagle mine case study. However, this study also investigates the merits of an "operational LCA" process that only includes emissions from operations phase could be used as a less resource intensive option for the analysis. The procedures for each analysis type are summarized in Table 7 and the results from both methods are discussed to understand the key differences and their causes. 
Table 7: Summary and Comparison of Detailed LCA and Operational LCA Methods.

\begin{tabular}{|c|c|c|}
\hline & Detailed LCA & Operational LCA \\
\hline Life cycle phases assessed & Construction, operations, maintenance & Operations \\
\hline Software Used & Simapro 8 & GREET 2016 \\
\hline Goal and Scope & $\begin{array}{l}\text { Goal: to compare CR-550, CR-595 and } \\
\text { Rail route emissions. } \\
\text { Functional unit: mine life (in years). } \\
\text { System boundary: construction, } \\
\text { operation and maintenance phases of } \\
\text { infrastructure and vehicles. Including } \\
\text { production and transportation of raw } \\
\text { materials. }\end{array}$ & $\begin{array}{l}\text { Goal: to compare CR-550, CR-595 } \\
\text { and Rail routes operational emissions. } \\
\text { Functional unit: mine life (in years). } \\
\text { System boundary: operation phase of } \\
\text { vehicles and life cycle of fuels from } \\
\text { well to wheel. }\end{array}$ \\
\hline Data & 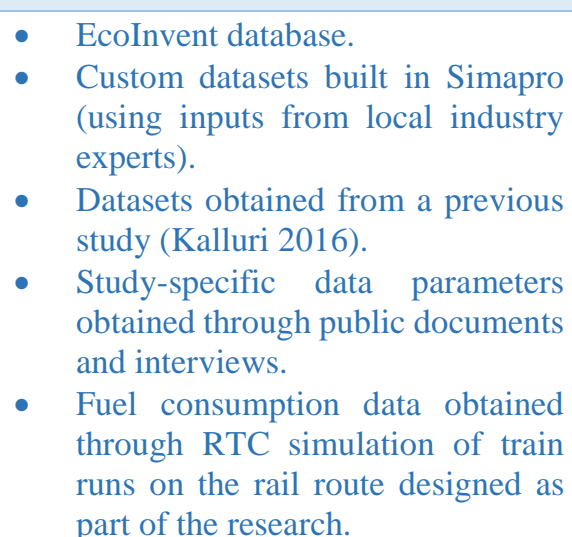 & $\begin{array}{l}\text { - Life cycle inventory available } \\
\text { within GREET. } \\
\text { - Study-specific data parameters } \\
\text { obtained through public } \\
\text { documents and interviews. } \\
\text { - Fuel consumption data obtained } \\
\text { through RTC simulation of train } \\
\text { runs on the rail route designed as } \\
\text { part of the research. }\end{array}$ \\
\hline Impact assessment method & $\begin{array}{l}\text { IPCC } 2013 \text { GWP 100a (Calculates } 100- \\
\text { year global warming potential of all the } \\
\text { greenhouse gases emitted, in terms of } \\
\mathrm{Kg} \mathrm{CO}_{2} \text { equivalents). }\end{array}$ & $\begin{array}{l}\text { GHG } 100 \text { (calculates } 100 \text {-year global } \\
\text { warming potential of major } \\
\text { greenhouse gases emitted }\left(\mathrm{CO}_{2}, \mathrm{CH}_{4}\right. \\
\text { and } \mathrm{N}_{2} \mathrm{O} \text { ), in terms of } \mathrm{Kg} \mathrm{CO}_{2} \\
\text { equivalents). }\end{array}$ \\
\hline Interpretation & $\begin{array}{l}\text { Analysis of the project stages or } \\
\text { assemblies created in Simapro. Direct } \\
\text { output comparison of the three } \\
\text { alternatives. }\end{array}$ & $\begin{array}{l}\text { The GHG-100 results (GHG } \\
\text { emissions per ton-mile) used to } \\
\text { calculate the operation phase } \\
\text { emissions of the three alternatives. }\end{array}$ \\
\hline
\end{tabular}




\subsection{LCA Steps}

The LCA in this study consists mainly of the calculation of the carbon footprint for the alternatives and is performed according to the ISO 14040: 2006 framework. The framework divides the process into four main steps; Goal and Scope definition, Inventory analysis, Impact assessment and Interpretation.

\subsubsection{Goal and Scope Definition}

Goal shall clearly define the main purpose of performing the LCA. The goal of LCA for both methods is to compare the route/mode alternatives based on greenhouse gas emissions over 8, 9, 10, 15, and 20 year life cycles of Eagle mine, assuming uniform annual production capacity (the amount of copper/ nickel ore mined per year). These mine lives were selected to account for potential short ( 1 year) and long ( 5 year) extensions due to the ongoing exploration for additional resources surrounding the mine location. The intended audience of this LCA would be the mining company, and govt. agencies responsible for making infrastructure decisions.

Scope definition involves identifying the functional unit for comparing the alternatives and the system boundary to determine which unit processes shall be included within the study. The mine life in years is adopted as the functional unit in both LCAs, i.e. the final results are estimated for each alternative in terms of the total emissions expected to arise over the mine life cycle. However, the system boundary varies. System boundary in Detailed LCA encompasses the unit processes in the construction, operation and maintenance phases of infrastructure and vehicles, including the extraction and transportation of raw materials used in those processes. In Operational LCA, only the operations phase to move the ore, including vehicles and life cycle of fuels from well to wheel (from the point of extraction to combustion) are included in the system boundary.

\subsubsection{Inventory Analysis}

Inventory analysis involves identifying, collecting and calculating all the relevant inputs and outputs for the processes and product systems such as materials, emissions, and energy. A majority of data for the detailed LCA is obtained from EcoInvent database [34]. Processes unavailable in EcoInvent or needing regional/project specific data are developed from other sources in the form of custom datasets. Data has been obtained from local industry experts, project stakeholders, or from the previous study by Kalluri et al. [6]. The list of the datasets used and details of units and quantities for all processes are provided in Appendix-2. For the rail alternative, fuel consumption data was obtained through RTC simulation of train runs on the conceptual rail route designed as part of this research. The core parameters for the three routes evaluated are presented in Table-8. 
Table 8: Input Parameters for Detailed LCA

\begin{tabular}{|c|c|c|c|c|}
\hline SL \# & Parameter & $\begin{array}{l}\text { CR-550 } \\
\text { Route }\end{array}$ & $\begin{array}{l}\text { CR-595 } \\
\text { Route }\end{array}$ & Rail Route \\
\hline \multicolumn{5}{|c|}{ Construction Phase } \\
\hline 1. & Length of Route (miles) & 65 & 24 & 24.66 \\
\hline 2. & $\begin{array}{l}\text { Heavy Reconstruction/ } \\
\text { New Construction (miles) }\end{array}$ & 14.4 & 22 & 21.06 \\
\hline 3. & $\begin{array}{l}\text { Light Reconstruction } \\
\text { (miles) }\end{array}$ & 12.1 & 0 & 0 \\
\hline 4. & $\begin{array}{l}\text { Number of Vehicles for } \\
\text { Ore Movements }\end{array}$ & 9 & 4 & $\begin{array}{l}1 \text { Locomotive } \\
\text { (AC 4,400 hp) } \\
20 \text { Railcars } \\
\text { (Hopper Cars) }\end{array}$ \\
\hline \multicolumn{5}{|c|}{ Operations Phase } \\
\hline 1. & $\begin{array}{l}\text { Round Trip Distance } \\
\text { (miles) }\end{array}$ & 130 & 48 & 49.32 \\
\hline 2. & $\begin{array}{l}\text { Number of Round Trips } \\
\text { Per Day }\end{array}$ & 44 & 44 & 1 \\
\hline 3. & $\begin{array}{l}\text { Fuel Burned per roundtrip } \\
\text { (gal) }\end{array}$ & $\begin{array}{l}37.14 \\
\text { (@3.5mpg) }\end{array}$ & $\begin{array}{l}12.57 \\
\text { (@3.5mpg) }\end{array}$ & 87.24 (RTC) \\
\hline 4. & Days of operation in a year & 365 & 365 & 365 \\
\hline 5. & $\begin{array}{l}\text { Fuel Consumption Per } \\
\text { Year }\end{array}$ & 596,515 & 201,897 & 31,843 \\
\hline \multicolumn{5}{|c|}{ Maintenance Phase } \\
\hline \multicolumn{5}{|c|}{ Infrastructure } \\
\hline 1. & $\begin{array}{l}\text { Nature and Frequency of } \\
\text { Maintenance Cycles }\end{array}$ & $\begin{array}{l}\text { No Significant } \\
\text { Maintenance } \\
\text { up to 20-years }\end{array}$ & $\begin{array}{l}\text { No Significant } \\
\text { Maintenance } \\
\text { up to } 20 \text {-years }\end{array}$ & $\begin{array}{l}\text { Ballast : } 15 \% \\
\text { every } 10 \text { years } \\
\text { Ties: } 14 \% \\
\text { every } 5 \text { years }\end{array}$ \\
\hline
\end{tabular}




\begin{tabular}{|c|c|c|c|c|}
\hline 1. & $\begin{array}{l}\text { Truck Maintenance Cycles } \\
\text { per year per truck (once in } \\
15000 \text { miles) }\end{array}$ & 16 & 13 & N/A \\
\hline 2. & $\begin{array}{l}\text { Total Truck Maintenance } \\
\text { Cycles in One Year (of all } \\
\text { trucks) }\end{array}$ & 144 & 52 & N/A \\
\hline 3. & $\begin{array}{l}\text { Frequency of Tire } \\
\text { Replacement (miles) }\end{array}$ & $\begin{array}{l}\text { Drive \&steer } \\
\text { tires: } 75000 \\
\text { Trailer: } \\
130000\end{array}$ & $\begin{array}{l}\text { Drive \&steer } \\
\text { tires: } 75000 \\
\text { Trailer: } \\
130000\end{array}$ & N/A \\
\hline 4. & Locomotive & N/A & N/A & Monthly \\
\hline \multicolumn{5}{|c|}{ Snow removal (Maintenance Phase) } \\
\hline 1. & $\begin{array}{l}\text { Hours of snow removal per } \\
\text { day }\end{array}$ & 36 & 24 & N/A \\
\hline 2. & Number of Plow Trucks & 3 & 2 & N/A \\
\hline 3. & $\begin{array}{l}\text { Days of Snow Removal in } \\
\text { a Year }\end{array}$ & 136 & 136 & N/A \\
\hline 4. & $\begin{array}{l}\text { Fuel Consumption per hour } \\
\text { (gal) }\end{array}$ & 5 & 5 & N/A \\
\hline 5. & $\begin{array}{l}\text { Fuel Consumption per year } \\
\text { (gal) }\end{array}$ & 24480 & 16200 & N/A \\
\hline
\end{tabular}

Operational LCA is performed using GREET model, which has a built-in data pertaining to the life cycles of a wide range vehicles and fuels. Since the exact vehicle type used in Eagle mine (11-axle Michigan mining truck with gross vehicle weight of 164,000 lbs.) was not available in GREET, a vehicle class with closest resemblance, namely HD Truck Combination Short Haul CIDI- Low Sulfur Diesel [37], was chosen and the fuel mileage and load capacity were modified using the edit vehicles option available in the GREET's well to wheel model [38]. The same fuel consumption characters were used in both Detailed and Operational LCA methods. Similarly, Freight Train-Conventional Diesel was chosen for the rail option, but its fuel mileage (mpg-diesel) and load characteristics were modified to match the average fuel consumption of empty and loaded train (obtained from RTC simulation).

The datasets and processes illustrated in Appendix-2 were obtained from Kalluri et al. 2016 [6] and modified as necessary for the Detailed LCA process in this project. The tables list and detail all the EcoInvent/Custom datasets corresponding to each process involved in the 
construction, operations and maintenance phases of the alternatives. In addition, they also explain the various data inputs and the logic behind their calculation. Most of the datasets are used without any modification, since they represent the same geographic location and similar scenarios. However some processes like Track construction and Track maintenance were modified based on data specific to this project. For example, the Track construction dataset in the Kalluri et al (2016) project was developed for construction on existing track bed and was modified to include the process of constructing the subgrade (track bed). However, construction of necessary embankments, or excavation for potential cut sections were excluded.

\subsubsection{Impact Assessment}

This step involves choosing a specific environmental impact or a range of impacts to be assessed in the analysis. For the detailed LCA, IPCC 2013 GWP 100a was selected as the assessment method. It is an impact assessment method for calculating 100-year Global Warming potential in terms of $\mathrm{kg} \mathrm{CO}_{2}$ equivalents of all the greenhouse gases emitted during a process. In case of Operational LCA, after selecting and modifying the vehicle and fuel types, GHG 100 was selected as a basis for emission calculations. The output includes 100-year global warming potential of major greenhouse gases emitted $\left(\mathrm{CO}_{2}, \mathrm{CH}_{4}\right.$ and $\left.\mathrm{N}_{2} \mathrm{O}\right)$, in terms of $\mathrm{kg} \mathrm{CO}$ equivalents [39]. GREET can compute these results with various base units such as mega joules (MJ), mile, $\mathrm{km}$, ton-mile, ton-km and passenger-mile. Ton-mile was selected as the base unit for the purpose of this study. The results per ton-mile obtained from GREET were used to compute the total emissions over mine life.

\subsubsection{Interpretation}

The findings from the inventory analysis and impact assessment stages are combined together in this stage, forming the final outcomes of LCA. In detailed LCA, analysis of the project stages or assemblies created in the inventory analysis stage is done using the impact assessment method selected in the previous stage. In operational LCA, the GHG-100 result obtained in terms of emissions per ton-mile is used to calculate the operation phase emissions over the different mine lives using the operation characteristics like route distance and number of trips. These results are discussed in detailed in the results section of this report. 


\section{Results}

This section discusses the results obtained from the life cycle assessments performed by the two methods. The results are presented in a graphical format to facilitate discussion of different phases, methods, and mine lives. A complete set of calculations and results is presented in tabular format in Appendices 3 and 4.

\subsection{Detailed LCA}

Figure 9 represents the cumulative results of the detailed LCA of CR-550, CR-595 and the rail routes over $8,9,10,15$ and 20-year mine lives and shows their breakdown between construction, operations and maintenance phases. As mentioned earlier, the 100-year global warming potential of GHG emissions were calculated in terms of tons of $\mathrm{CO} 2$ equivalents. The Figure reveals that for road alternatives the total operation phase emissions dominate the emissions over construction and maintenance phases, while the construction phase dominates the emissions for the rail alternative for all mine lives.

The operation phase emissions increase linearly with increase in mine life while the infrastructure emissions remain fairly static, as a major portion of construction activity takes place at the initial stage of mine life and only a small amount of additional construction activity with regard to new equipment would occur during later years. In case of operations, the linear increase is to be expected, as the annual ore transportation remains static and each additional load of ore adds to the cumulative operational emissions. Rail alternative follows a similar pattern, although the operational emissions are much lower and grow at slower pace. It should be noted that the construction phase of rail alternative considered a standard embankment throughout the route. In reality, emissions from construction would likely be higher due to required bridges, etc. All infrastructure development is assumed to take place during the first year of the project, making them non-existent for the remaining mine life. The maintenance emissions account for much smaller portion than the other two categories and slowly escalate for longer mine lives, due to aging equipment. 


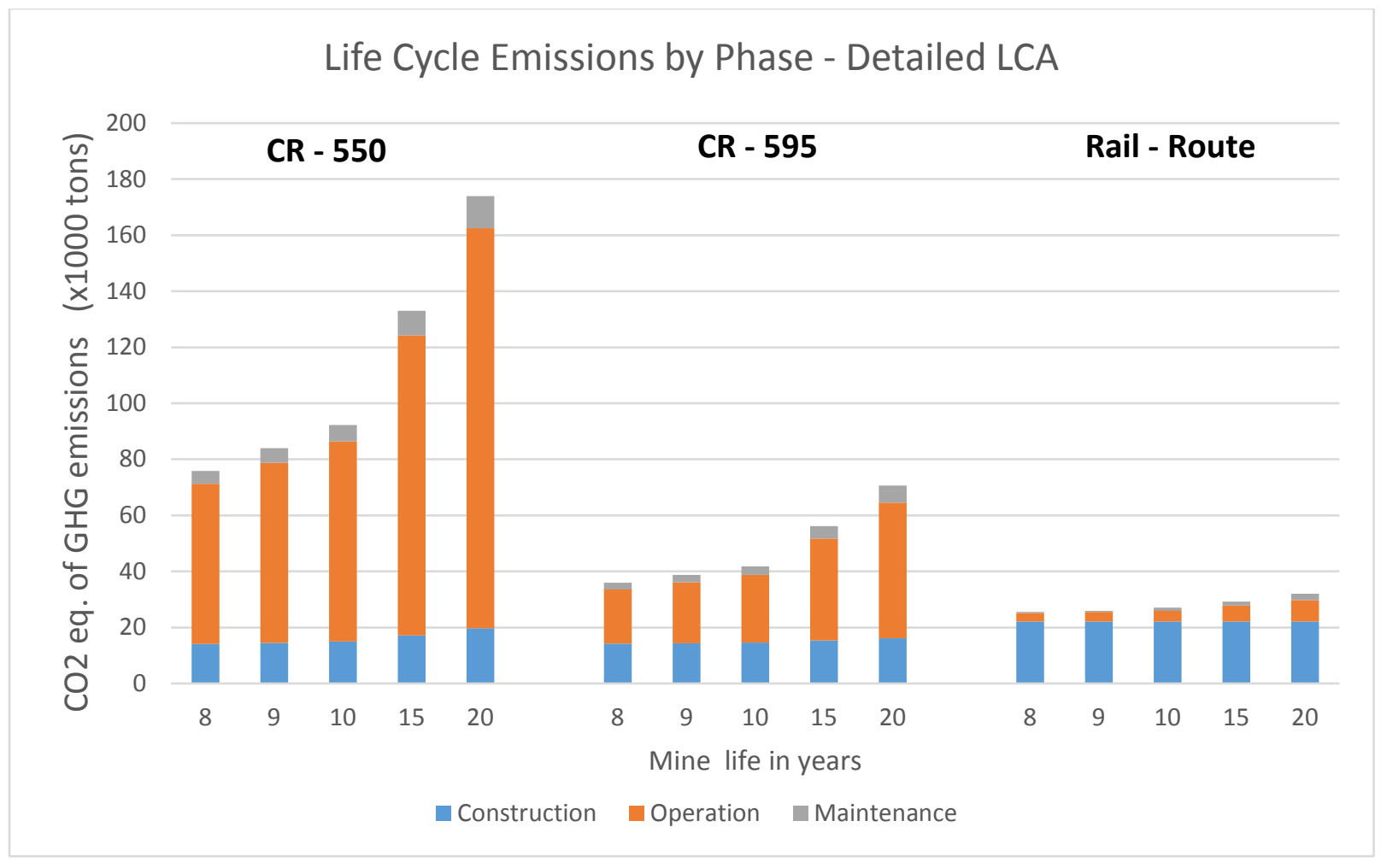

Figure 9: Phase-Wise Life Cycle Emissions Estimated Using Detailed LCA.

The detailed LCA results discussed above use several custom datasets with regional and case specific data to improve accuracy and reliability. The EcoInvent 3.0 database also offers comprehensive datasets for several processes constituted in the case study, for example, processes like road construction and railway track construction. However, these relatively generalized datasets were developed using inputs that are industry averages pertaining to Europe. In addition, EcoInvent datasets for road/rail construction already incorporate maintenance activities with predetermined frequencies and material and energy quantities. Despite these differences, it was of interest to compare the separately developed custom datasets for road/rail construction and maintenance processes in this study with the ones provided by EcoInvent.

Figure 10 and figure 11 present the greenhouse gas emissions estimated using EcoInvent and custom datasets. In case of road, it can be observed that the emissions estimated using the custom datasets are much higher than those obtained using EcoInvent datasets and in case of rail it is the exact opposite. Moreover, the EcoInvent results increase consistently with time as they are calculated using a base unit that is a function of time and distance (meter.year). On the other hand the custom datasets are a more comprehensive representation of the expected actual construction and maintenance activities specific to this case study. These do not increase as much with time, as all construction is attributed to the initial year and the expected maintenance activities are nominal in both alternatives. The large difference between the results obtained through the two datasets is representative of the difference in the underlying assumptions regarding the intensity and frequency of the construction and maintenance activities. 


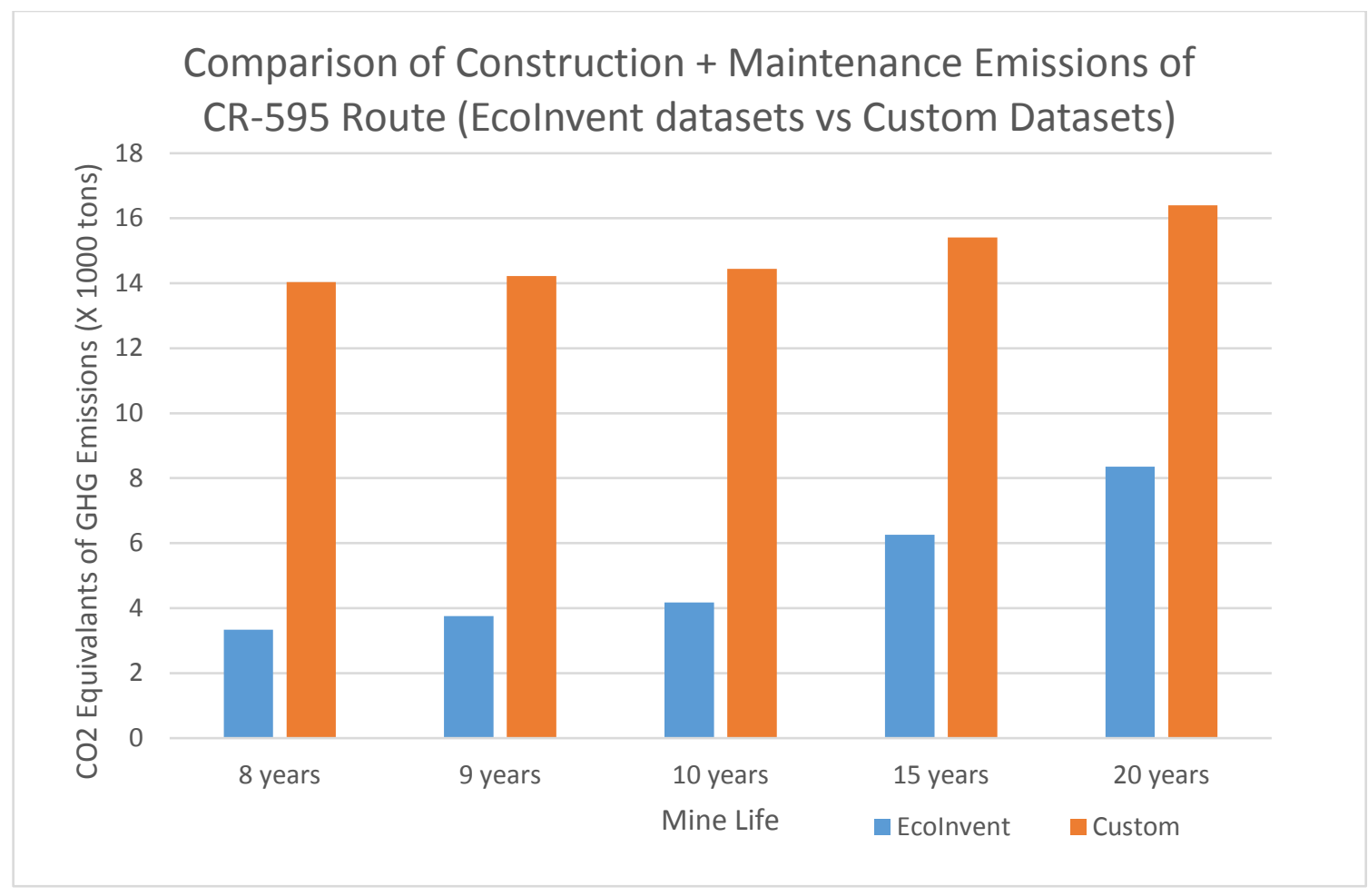

Figure 10: Greenhouse gas emissions of construction and maintenance phases of CR-595 route estimated using Ecolnvent and custom datasets

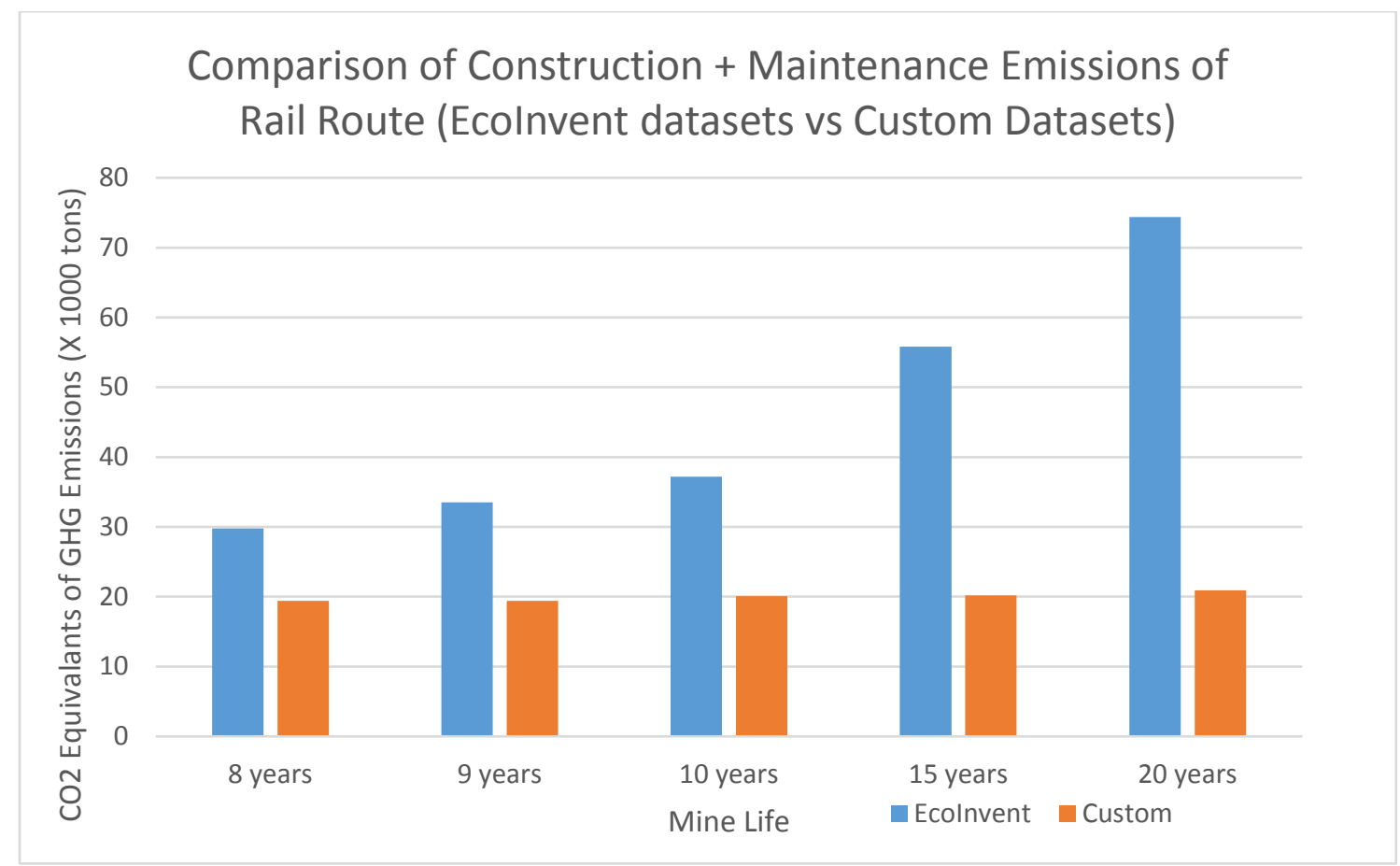

Figure 11: Greenhouse gas emissions of construction and maintenance phases of rail route estimated using Ecolnvent and custom datasets 


\subsection{Operational LCA}

After performing the analysis using Operational LCA method for the operations phase of all alternatives, the 100-year global warming potential of GHG emissions were calculated for selected mine lives in terms of tons of $\mathrm{CO} 2$ equivalents. These emissions were computed using the emissions results per ton-mile obtained from GREET, together with the route lengths and number of trips for each alternative. Figure 12 represents the results of the operational LCA of CR-550, CR-595 and the rail routes over 8, 9, 10, 15 and 20-year mine lives. The emission variation between the two truck routes is proportional with the difference in the lengths of the two routes. When comparing the rail route with the CR-595 route, the efficiency of rail transportation becomes evident. The length of each route is fairly similar, but the emissions arising from rail operations are much lower, irrespective of mine life.

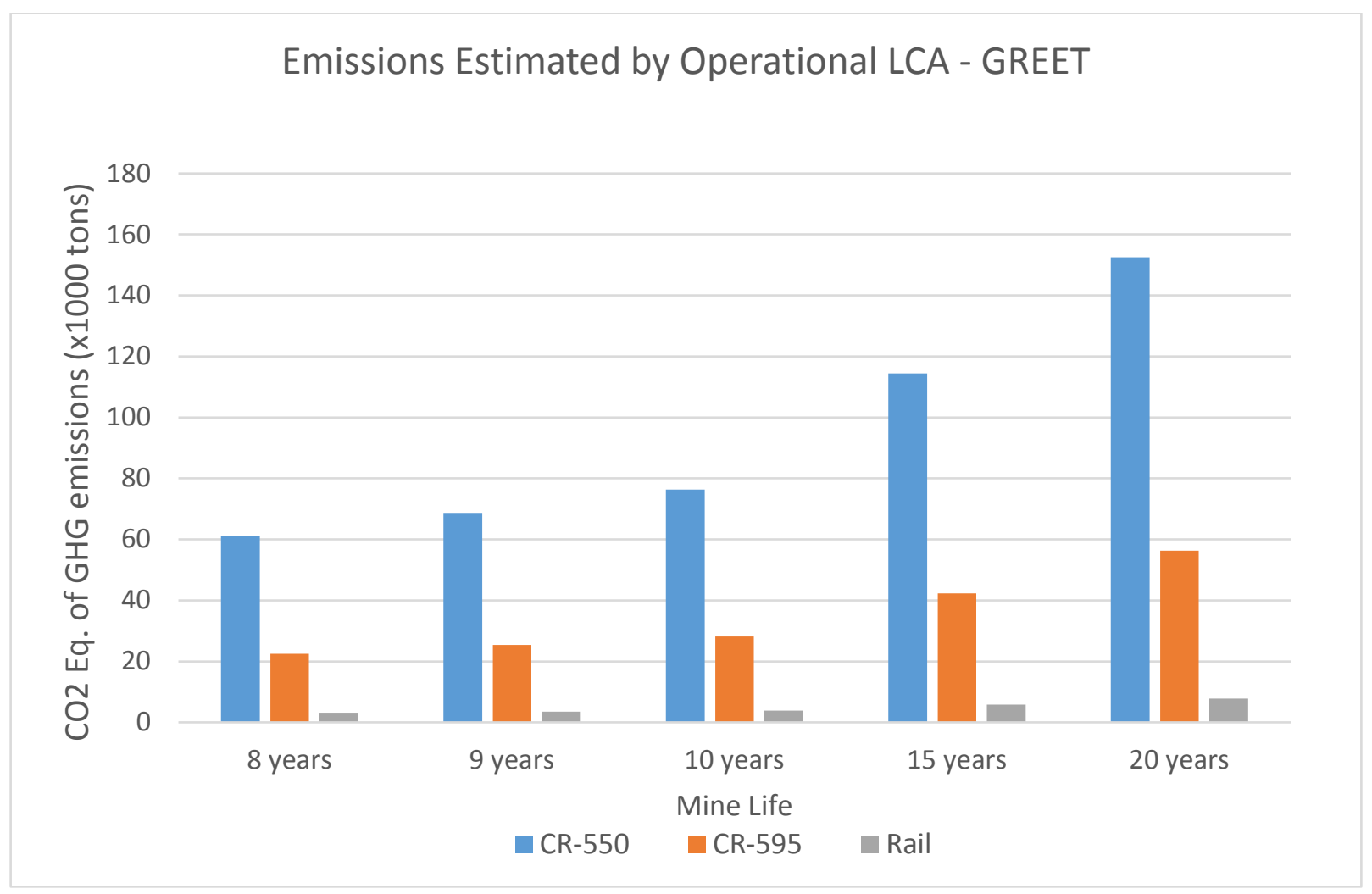

Figure 12: Results of Operational LCA

\subsection{Discussion of Results}

Table 8 presents the final results obtained from both methods side by side. The results from either method lead to the same conclusion that, irrespective of mine life CR-595 would generate less greenhouse gas emissions than CR-550 and rail option would generate the least emissions. Since the Operational LCA does not consider the emissions from the construction and maintenance phase activities, the emissions estimated are much lower compared to those estimated by Detailed LCA. The "\% diff" column shows that the exclusion of construction and maintenance from the analysis has a great significance in the total results, in the case of rail alternative over 80 
percent. This difference diminishes somewhat as the mine life increases, due to increasing share of operations phase emissions.

Given the differences in complexity and data required for the two methods, it was investigated whether the results for operations phase from each method were comparable. Figure 13 provides the operation phase emissions from detailed LCA with those estimated by the operational LCA method side by side. The graph (and Table 9) reveal that the two methods yielded similar results, but differences also existed. Operation phase emissions obtained from GREET are higher by an average of $6 \%, 16 \%$ and $2 \%$ for CR-550, CR-595 and the rail option, respectively. As seen in the percentages, the difference is not uniform between the routes, but it remains fairly consistent across the mine lives.

The main cause of deviation between SimaPro and GREET seems to be the difference in the approach of calculating emissions in the two methods, i.e. based on total fuel consumption in SimaPro (Detailed LCA) in contrast with emissions per ton-mile calculation in Operational LCA. In case of "operational LCA" emissions per ton-mile are constant between the two routes (81.2g). In contrast, when back-calculated from the total emissions of "detailed LCA", the average emissions per ton-mile are found to be 76g in CR-550 and 69.7g in CR-595. Operations phase emissions in detailed analysis are estimated entirely based on total fuel consumed, which is accounted for in two sub-processes i.e. fuel production and supply, and fuel combustion in diesel engine. Hence, with an increase in fuel consumption between CR-595 and CR-550 (nearly 3 times), there is an accelerated increase in emission results. Since the emissions per ton-mile results are higher in operational LCA for both routes, the difference between the two methods is much higher in case of shorter (CR-595) route. 
Table 9: Comparison of Results from Detailed LCA and Operational LCA (in Terms of $\mathrm{Kg} \mathrm{CO}_{2}$ Equivalents of Greenhouse Gas Emissions)

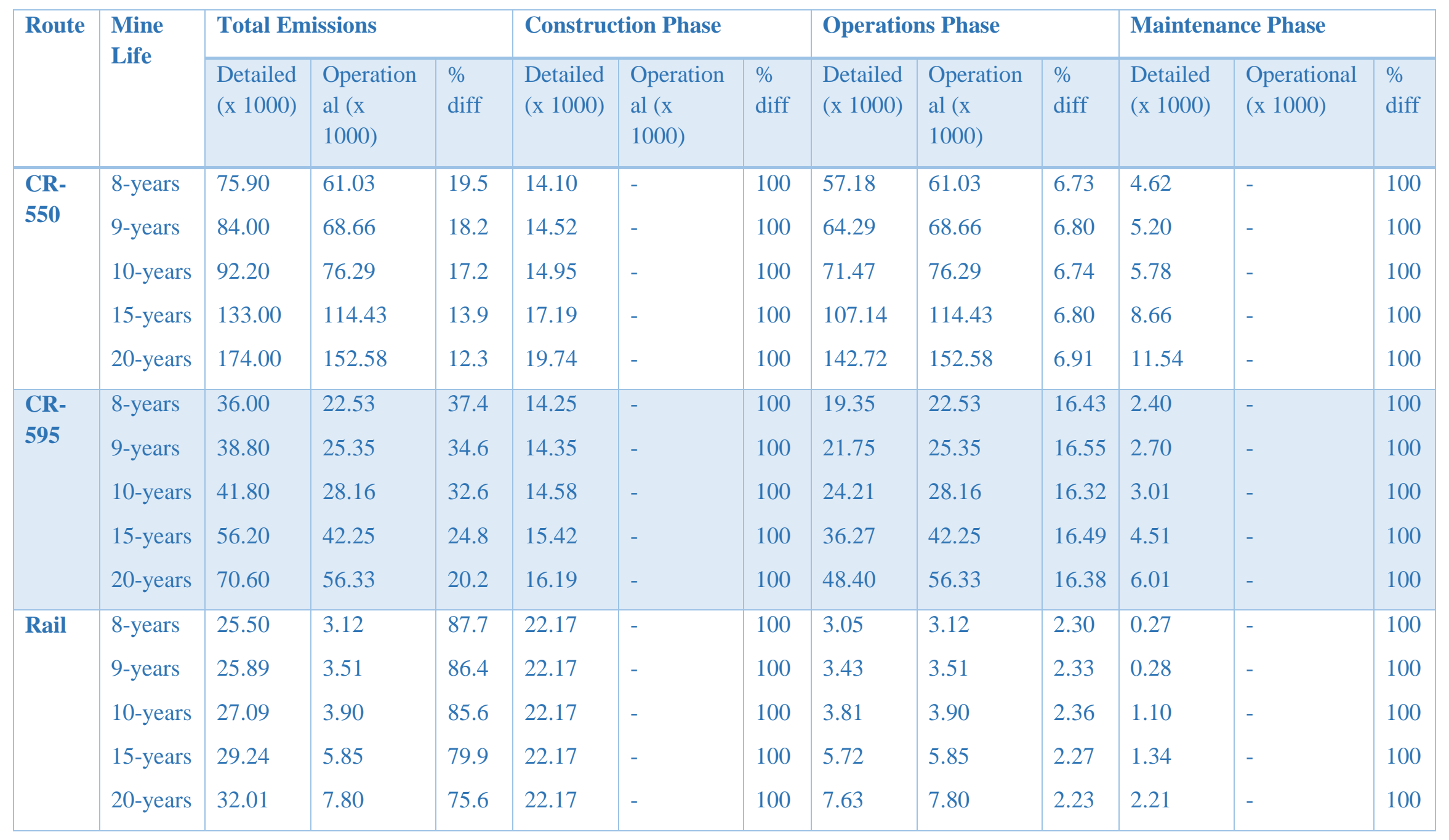




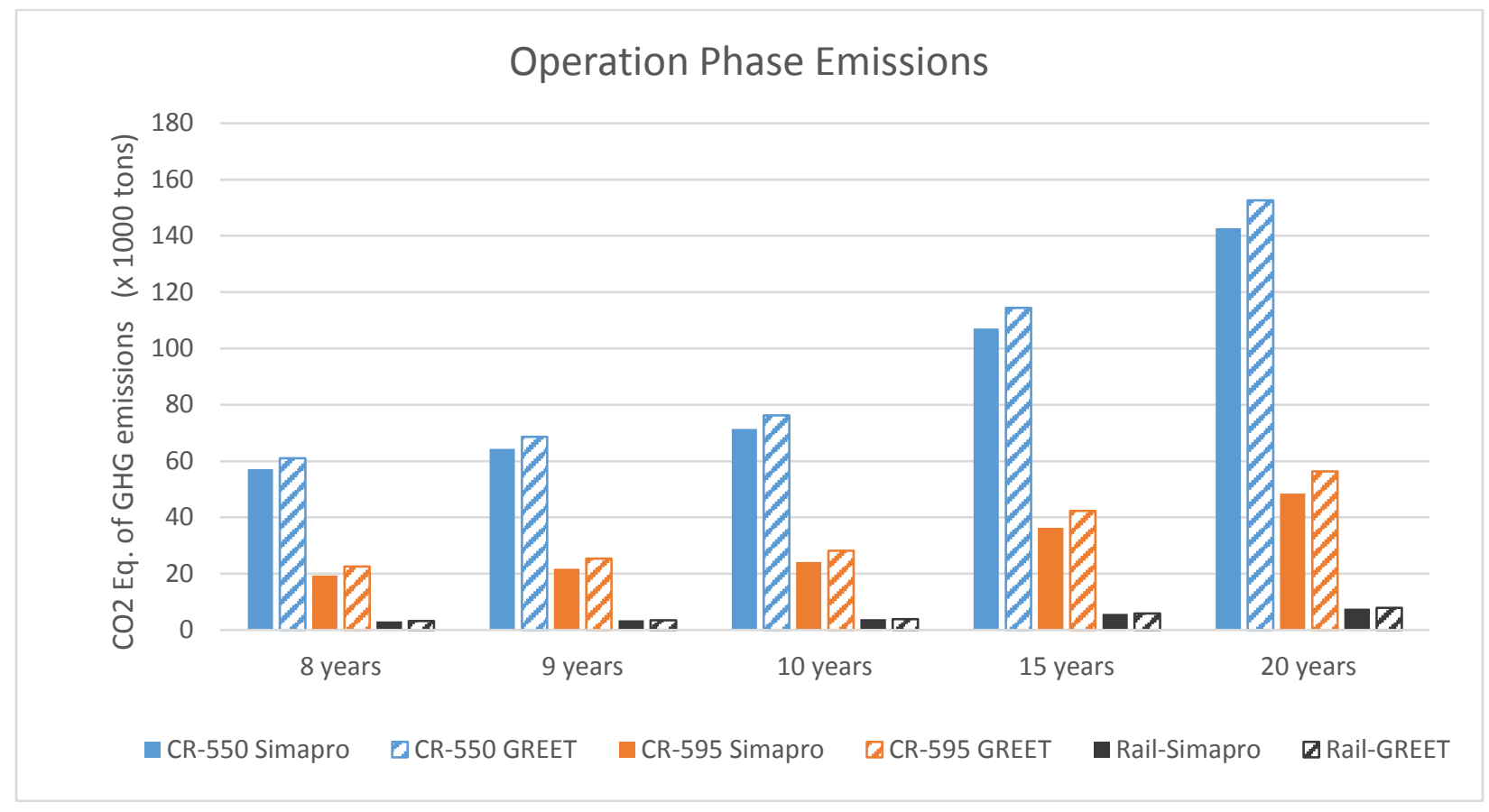

Figure 13: Comparison of Operation Phase Emissions Estimated by the Two Methods. 


\section{Conclusions}

The study used two variations of LCA (Detailed and Operational) to quantify and compare the greenhouse gas emissions (carbon footprint) of three route/mode alternatives for transporting nickel and copper ore from Eagle mine to Humboldt mill. The alternatives included the currently used highway route (CR-550), an alternative highway route (CR-595) considered in the planning stage of the mine, and a conceptual rail route designed as part of the study. The study estimated the potential greenhouse gas emissions from each route over mine lives of 8, 9, 10, 15 and 20 years. Detailed LCA covered the emissions from the complete life cycle of the alternative development, including construction, operation and maintenance phases of infrastructure and vehicles, while operational LCA covered only the operation phase emissions, which included the combustion of fuel in the vehicles and the full life cycle of those fuels. The detailed LCA was performed using SimaPro version 8 software with the support of the EcoInvent database v3.1 and custom datasets created from regional and case specific data. The operational LCA was performed using the GREET 2016 model with the help of the stock database available in the model itself. In addition to comparing the emissions effects of each alternative, another objective of this study was to investigate the breakdown of emissions between the construction, operations, and maintenance phases. In addition, it was investigated how closely the Operational LCA results matched the operations phase emissions obtained from the Detailed LCA.

Based on the analysis, CR-595 is a superior alternative between the two road options and the rail option is clearly the best among the three from emissions perspective, especially for the longer mine lives. It can be observed that the emissions in road alternatives arising from the operation phase are significantly higher than those from the construction and maintenance phases and they increase linearly with mine life. On the other hand, operation phase emissions are much lower than construction phase emissions in rail alternative. While they also increase linearly, their portion of the total emissions is lower than construction even for 20 year mine life. Overall, the infrastructure emissions exceed those from maintenance, but they both only increase moderately with mine lives in all options. Infrastructure is more significant, but for the rail option, maintenance becomes almost equal to operational emissions for the longest mine lives. Infrastructure emissions are also highly dependent on the data sources, as demonstrated by the significant differences between results obtained from analysis using custom data sets vs. general EcoInvent data sets.

There were some differences between the operation phase emissions estimated by the two methods (detailed and operational). This difference grew with increased total emissions and is presumably caused by the differences in equipment data available, and the life cycle inventories used by the two software. The operational LCA approach was able to provide the same ranking for compared alternatives, but this result only reflects the outcomes of this case study and can't be generalized. Based on the outcomes, it can be speculated that the operational LCA method is valid as a comparison method for projects that require only limited or very similar infrastructure upgrades in all the alternatives involved. However, with the infrastructure component gone, the detailed method also becomes more manageable. For projects with significant amount of 
new/reconstructed infrastructure, the operational method will give erroneous results, especially in the case of alternatives involving different modes of transportation, as the distribution of emissions between construction and operation phases is highly inconsistent between different modes. The detailed method is certainly preferred when it comes to generating accurate results, but operational method is better than simply ignoring the emission aspects, especially for project with long mine lives.

Another interesting outcome of this study is the potential of the rail route to serve the timber and forest products industry in the region. Since the majority of the rail alignment (at least 19.5 out of 24.66 miles) passes through commercial forest area known for its logging activities, the timber companies operating in this area could benefit from the alternative rail option, at the same time reducing emissions caused by their truck operations. The daily volumes of logs tend to be small and operating a train exclusively for log movements may not be feasible. However, it was found that approximately 15-20 additional railcars, each with a 100-ton payload capacity can be added to the train without exceeding the maximum hauling limit. Even though this would result in slight increase of fuel consumption and maintenance requirements, taking advantage of such synergies would result in reduction of overall emissions from both Eagle mine and timber operations. The additional infrastructure/operational costs could be recovered through the increased revenue from log movements.

\section{Recommendations for Future Research}

There is a significant potential for future research in the field of Transportation LCA. Specially for improving the process of performing comparative LCAs for freight transportation project alternatives. Standard analysis setups can be developed in the current LCA software like SimaPro or OpenLCA. These setups can be developed in such a way that, very little and basic data inputs would be required to perform an analysis. This can be achieved by identifying the most common scenarios in which a Transportation LCA would be performed, acquiring/creating the datasets required for all processes involved in the different life cycle phases, and subsequently integrating them in an analysis setup. This could significantly reduce the time and expertize required to perform an LCA. However, even with the limited amount of analysis conducted in this study, it is evident that the environmental differences can have great effect on the analysis outcomes, especially on the infrastructure emissions. Therefore, any standard/generalized databases must be considered with utmost caution and it is likely that custom datasets will still be needed in future projects.

Further, an exclusive software can be developed for Transportation LCA with inherent databases providing the required datasets and standard analysis setups. Also, from holistic perspective, it is important that emissions are included in the analysis of freight transportation project alternatives. Another potential area of research would be to convert the emissions calculated in this study to monetary values using carbon costs. This would enable the integration of emissions as a cost parameter in the economic analysis methods like Life Cycle Cost Analysis 
(LCCA), Economic Impact Analysis (EIA) and Benefit Cost Analysis (BCA) which are commonly used to compare transportation project alternatives. 


\section{References}

1. State., U.S.D.o., United States Climate Action report 2014. 2014, U.S. Department of State.: Washington D.C. p. 310.

2. $\quad$ Lee Schipper, L.S., Lynn Price, Energy Use And Carbon Emissions From Freight In 10 Industrialized Countries: An Analysis Of Trends From 1973 TO 1992. Elsevier Science, 1996. 2(1): p. 57-76.

3. Unep.org. Life Cycle Assessment. 2016 [cited 2017 04/25/2017]; Available from: http://www.unep.org/resourceefficiency/Consumption/StandardsandLabels/MeasuringSus tainability/LifeCycleAssessment/tabid/101348/Default.aspx.

4. Brown-Steiner, B., et al., Black carbon emissions from trucks and trains in the Midwestern and Northeastern United States from 1977 to 2007. Atmospheric Environment, 2016. 129: p. 155-166.

5. Christiano Facahna, A.H., Evaluation of Life-Cycle Air Emission Factors of Freight Transportation. Environ. Sci. Technol, 2007. 41.

6. Kalluri, S., Comparative Life Cycle Assessment Of Road And Multimodal Transportation Options - A Case Study Of Copperwood Project. 2016, Michigan Technological University: Houghton, Michigan, USA.

7. Laboratory, A.N. GREET Model. 2017 [cited 2017 04/25/2017]; Available from: https://greet.es.anl.gov/.

8. Eagle Mine, About Us. 2017 [cited 2017 04/25/2017]; Available from: http://eaglemine.com/about-us/.

9. Corporation, L.M. Operations And Development/ Eagle Mine, USA. 2017 [cited 2017 04/25/2017]; Available from: http://www.lundinmining.com/s/EagleMine.asp.

10. Eagle Mine Areal View. 2014 [cited 2017 5/24/2017]; Available from: https://www.facebook.com/lundineaglemine/photos/a.207419479465180.1073741827.20 0499583490503/242837315923396/?type=3\&theater.

11. Eagle Mine, Eagle East. 2017 [cited 2017 04/25/2017]; Available from: http://eaglemine.com/eagleeast/.

12. Eagle Mine, Operations. 2017 [cited 2017 04/25/2017]; Available from: http://eaglemine.com/operations/.

13. Humboldt Mill Ariel View. 2014 [cited 2017 5/24/2017]; Available from: https://www.facebook.com/lundineaglemine/photos/a.207420019465126.1073741828.20 0499583490503/273755402831587/?type=3\&theater.

14. Revised Alternatives Analysis and Project Assessment For Proposed County Road 595, M.C.R. Commission, Editor. 2012, MCRC: Marquette, MI.

15. Eagle Mine Ore Truck. 2014 [cited 2017 5/25/2017]; Available from: https://www.facebook.com/lundineaglemine/photos/a.207420019465126.1073741828.20 0499583490503/234238136783314/?type=3\&theater.

16. Marquette City Officials Discuss Truck Routes and County Road 595, in Sunny.FM. 2013, wkqsfm.com: Marquette, Michigan.

17. Iwanicki, J., Interview, Marquette County Road Comission, S. Kalluri, Editor. 2015: Houghton, Michigan.

18. Wyant, D., MDEQ Letter (January 3rd, 2013), D.o.E. Quality, Editor. 2013, State of Michigan: Lansing. 
19. Jones, C., Mineral Range Railroad, Personal Meeting, S. Oduru; and P. Lautala, Editors. 2016: Houghton, Michigan.

20. U.S. Geological Survey NED n47w088 1/3 arc-second 20131 x 1 degree IMG, in 10 Meter DEM, U.S.G. Survey, Editor. 2013, USGS: United States.

21. Michigan Geographic Framework All roads, M.G.D. Library, Editor. 2014, Michigan DTMB: Lansing, MI, USA.

22. Michigan Geographic Framework Railroads, M.G.D. Library, Editor. 2014, Michigan DTMB: Lansing, MI, USA.

23. Michigan Wetlands, in National Wetlands Inventory, U.S.F.a.W. Services, Editor. 2016, https://www.fws.gov/wetlands/Data/Mapper.html: United States.

24. Michigan Geographic Framework Hydrography Polygons and Hydrography Polylines, M.G.D. Library, Editor. 2016, http://www.mcgi.state.mi.us/mgdl/?rel=ext\&action=sext: Lansing, MI, USA.

25. CSX-Transportation, Standard Specifications For The Design And Construction Of Private Sidetracks, in Design Criteria. 2007, CSX Transportation: Jacksonville, Florida.

26. Berkeley Simulation Software, L. What Is RTC. Rail Traffic Controller [cited 2017 5/8/2017]; Available from: http://www.berkeleysimulation.com/rtc.php.

27. Dirden, P., BNSF 5838, in Flickr, B. 5838, Editor. 2007, Flickr: Plumas, California.

28. Michigan Commercial Forest Act Lands, M.D.o.N. Resources, Editor. 2017, State of Michigan: Michigan.

29. Curran, M.A., A Brief History of Life-Cycle Assessment, in LIFE CYCLE ASSESSMENT: PRINCIPLES AND PRACTICE. 2006, U.S. Environmental Protection Agency: Cincinnati, Ohio.

30. Standardization, I.O.f., Environmental management - Life cycle assessment - Principles and framework. 1997, ISO: Geneva, Switzerland.

31. Eom, J., L. Schipper, and L. Thompson, We keep on truckin': Trends in freight energy use and carbon emissions in 11 IEA countries. Energy Policy, 2012. 45: p. 327-341.

32. SZOEGE, H.M., Environmental impact of rail and road transport. Economics and Environmental studies, 2011. 11(4): p. 405-421.

33. Torsten Marheineke, Rainer Friedrich, and W. Krewitt, Application of a Hybrid-Approach to the Life Cycle Inventory Analysis of a Freight Transport Task, in Total Life Cycle Conference and Exposition. 1998, SAE International: Graz, Austria.

34. Spielmann, M. and R. Scholz, Life Cycle Inventories of Transport Services: Background Data for Freight Transport (10 pp). The International Journal of Life Cycle Assessment, 2004. 10(1): p. 85-94.

35. James J. Winebrake, J.J.C., J. Scott Hawker, Karl Korfmacher, Intermodal Freight Transport in the Great Lakes: Development and Application of a Great Lakes Geographic Intermodal Freight Transport Model. 2008, Rochester Institute of Technology: Rochester, NY.

36. Sumanth Kalluri, P.L., Robert Handler, Comparative Life Cycle Assessment Of Road And Multimodal Transportation Options - A Case Study Of Copperwood Project, in Transportation Research Board Annual Conference. 2016: Washington, DC.

37. Hao Cai , A.B., Michael Wang, Wen Hang, Anant Vyas, The GREET Model Expansion for Well-to-Wheels Analysis of Heavy-Duty Vehicles. 2015, Argonne National Laboratory: Alexandria, VA. 
38. Laboratory, A.N. Edit Vehicles. GREET 2012 [cited 2017 04/25/2017]; Available from: https://wiki.anl.gov/greetnet_help/Edit_Vehicles\#Creating_Vehicles.

39. Wang, M.Q., GREET 1.0 - Transportation Fuel Cycles Model: Methodology and Use. 1996, Center for Transportation Research. 


\section{Appendices}

Appendix-1: Conceptual Rail Alignment - Horizontal and Vertical Plan Sheets The following sheets provide horizontal alignments of the conceptual rail route. 


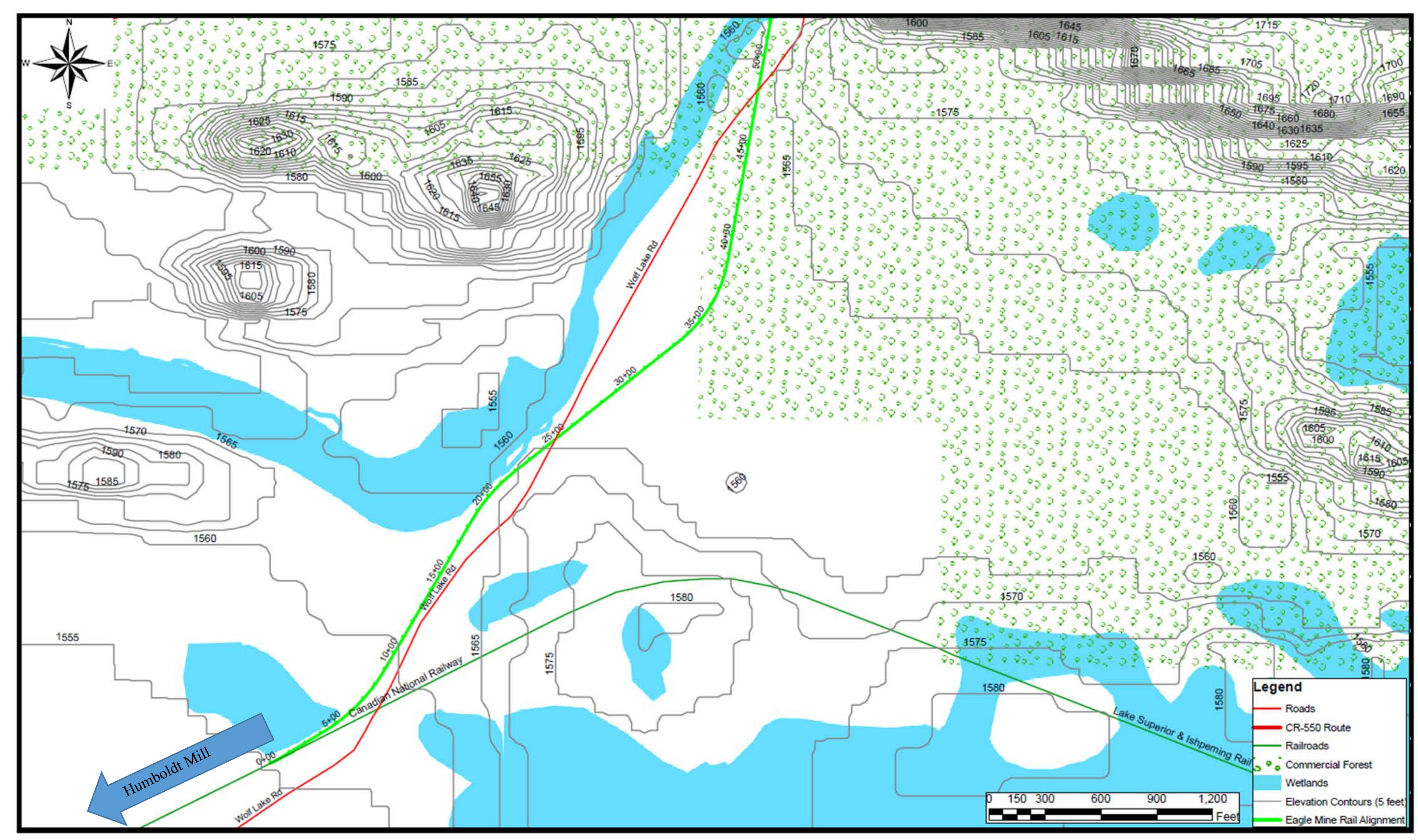




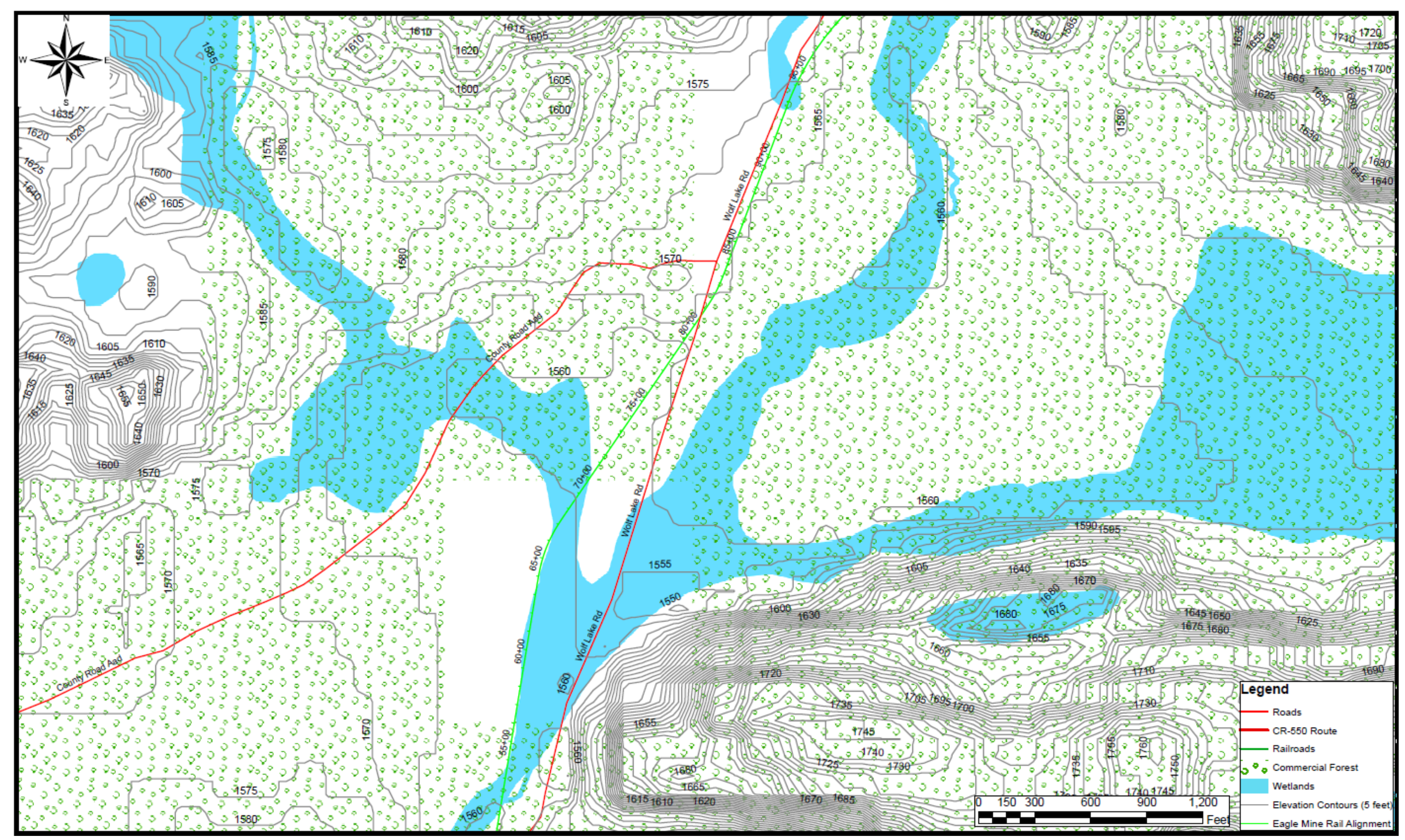




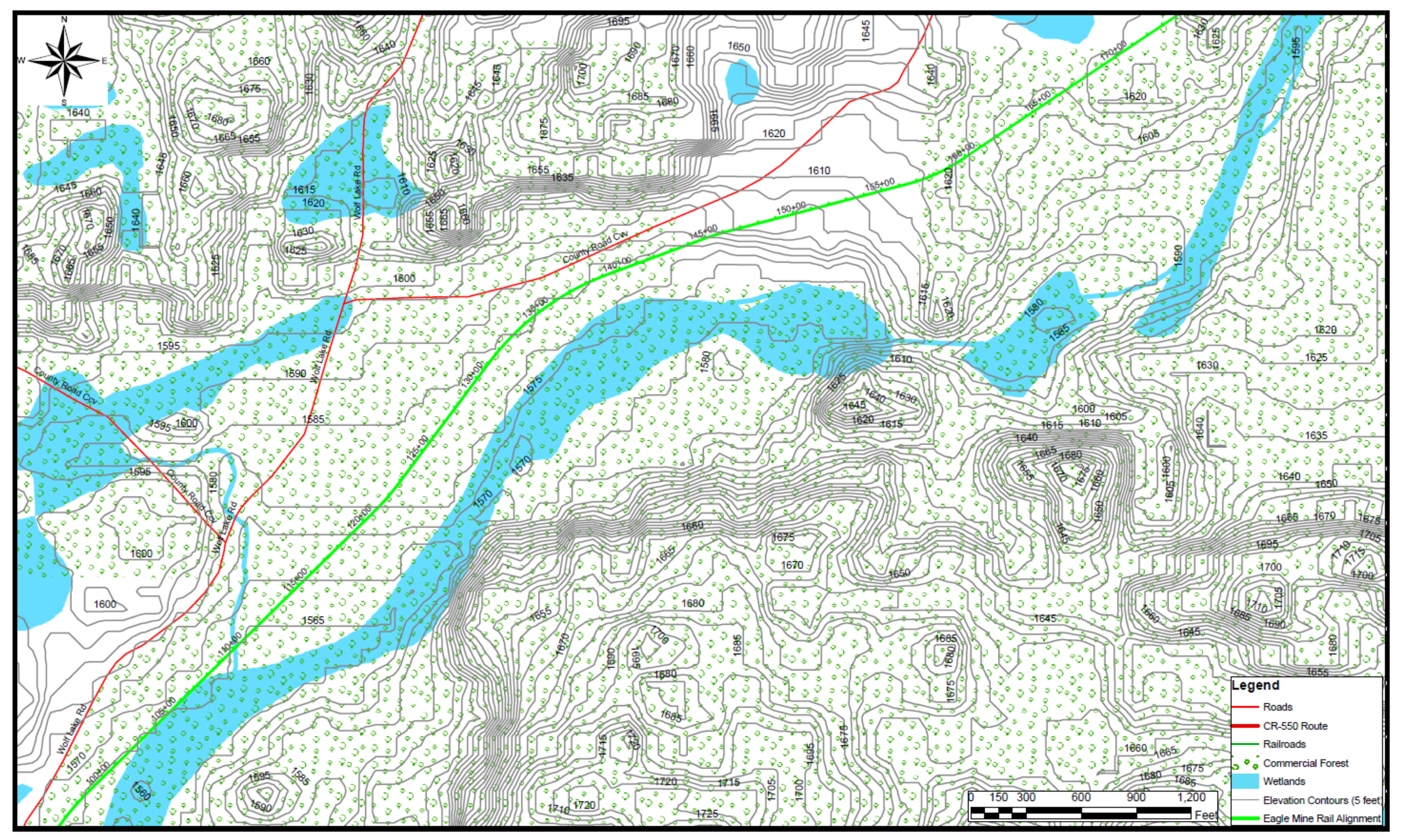




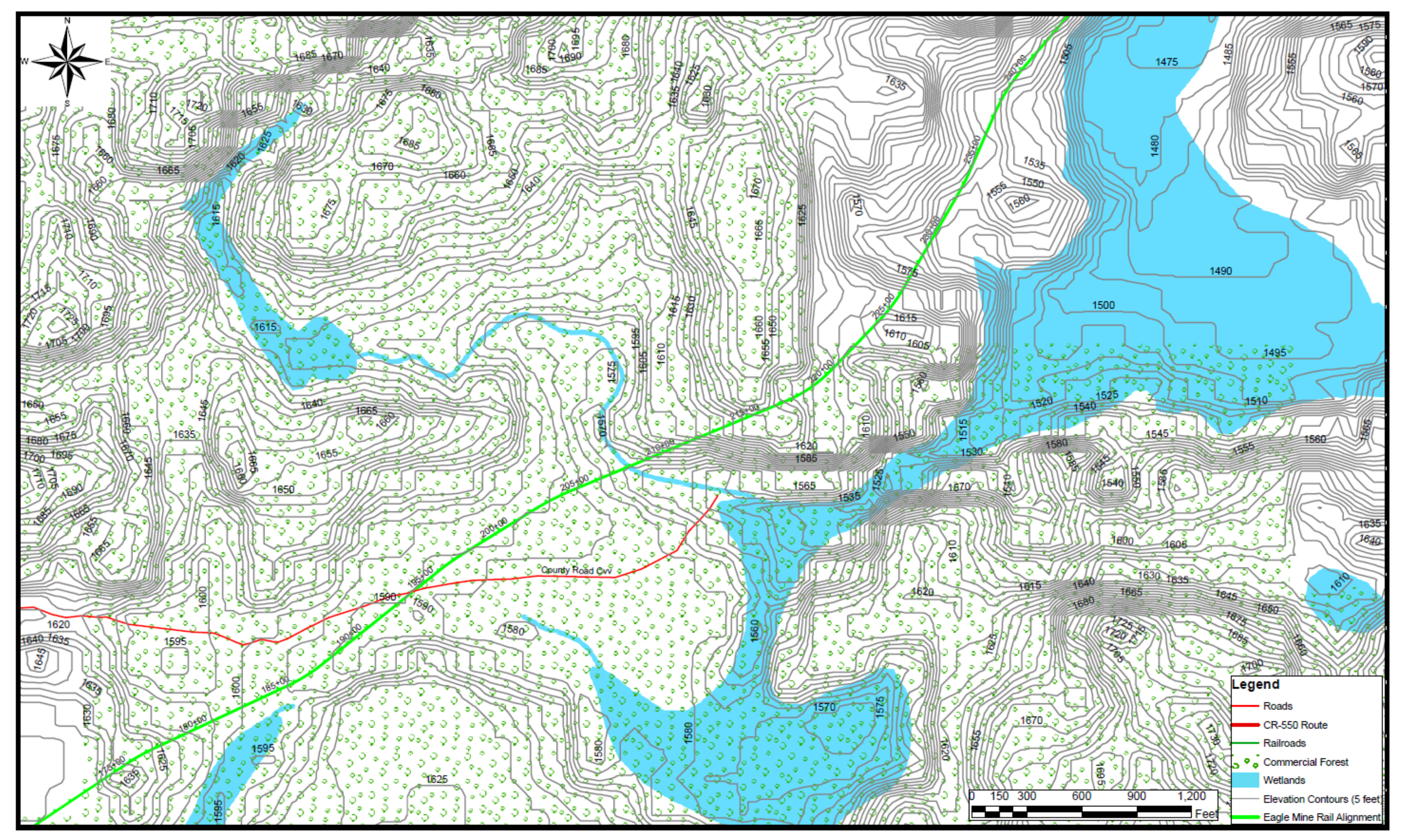




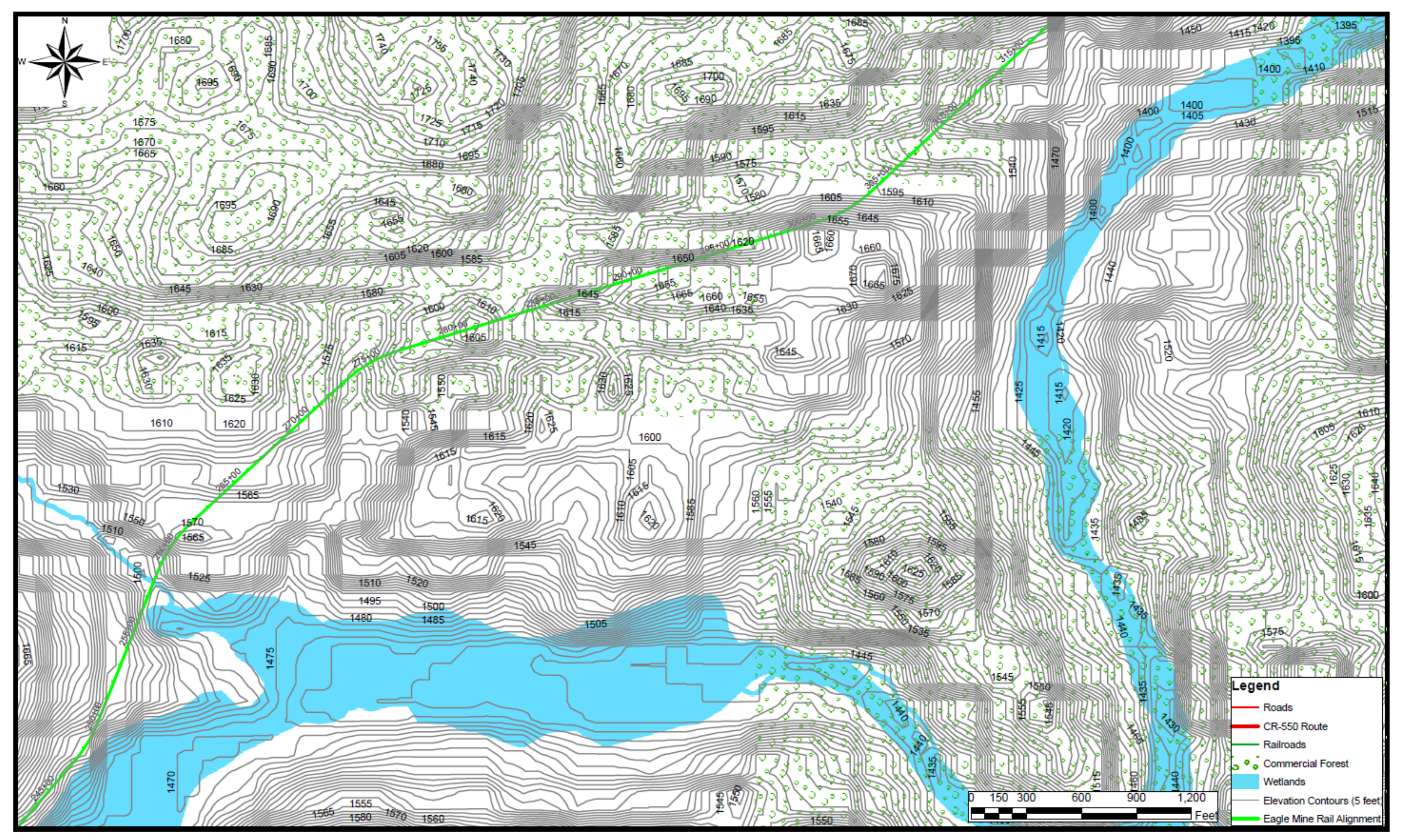




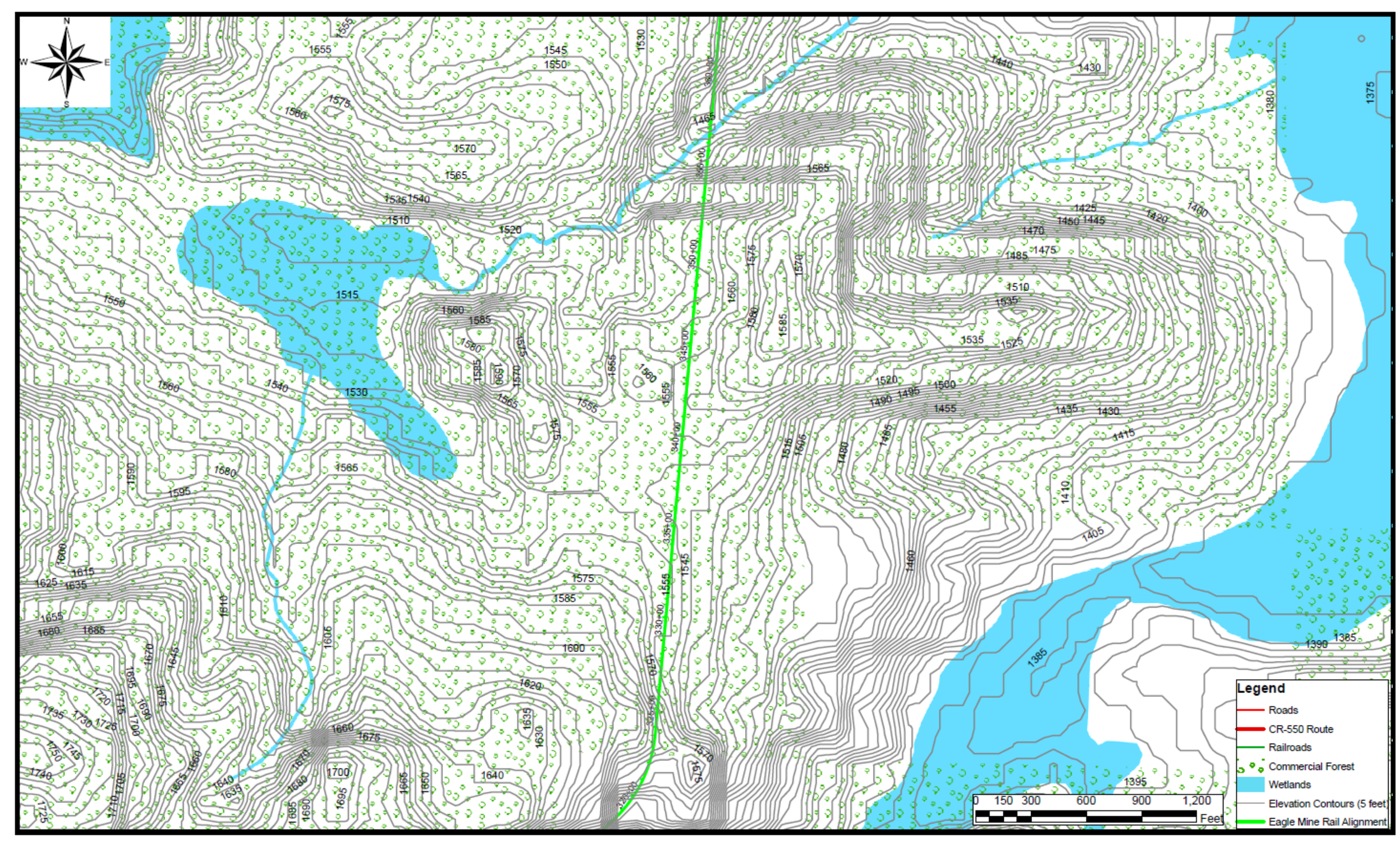




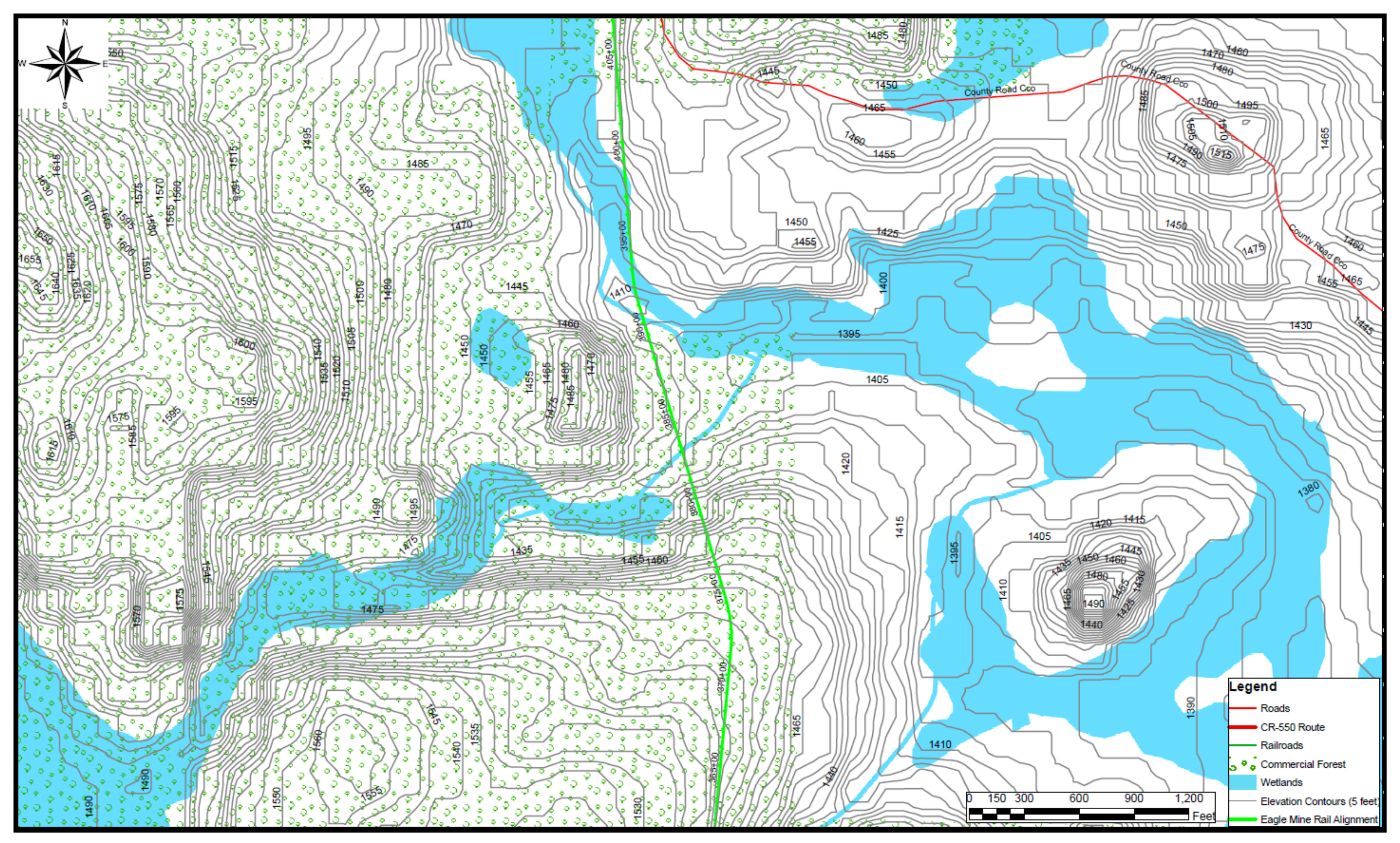




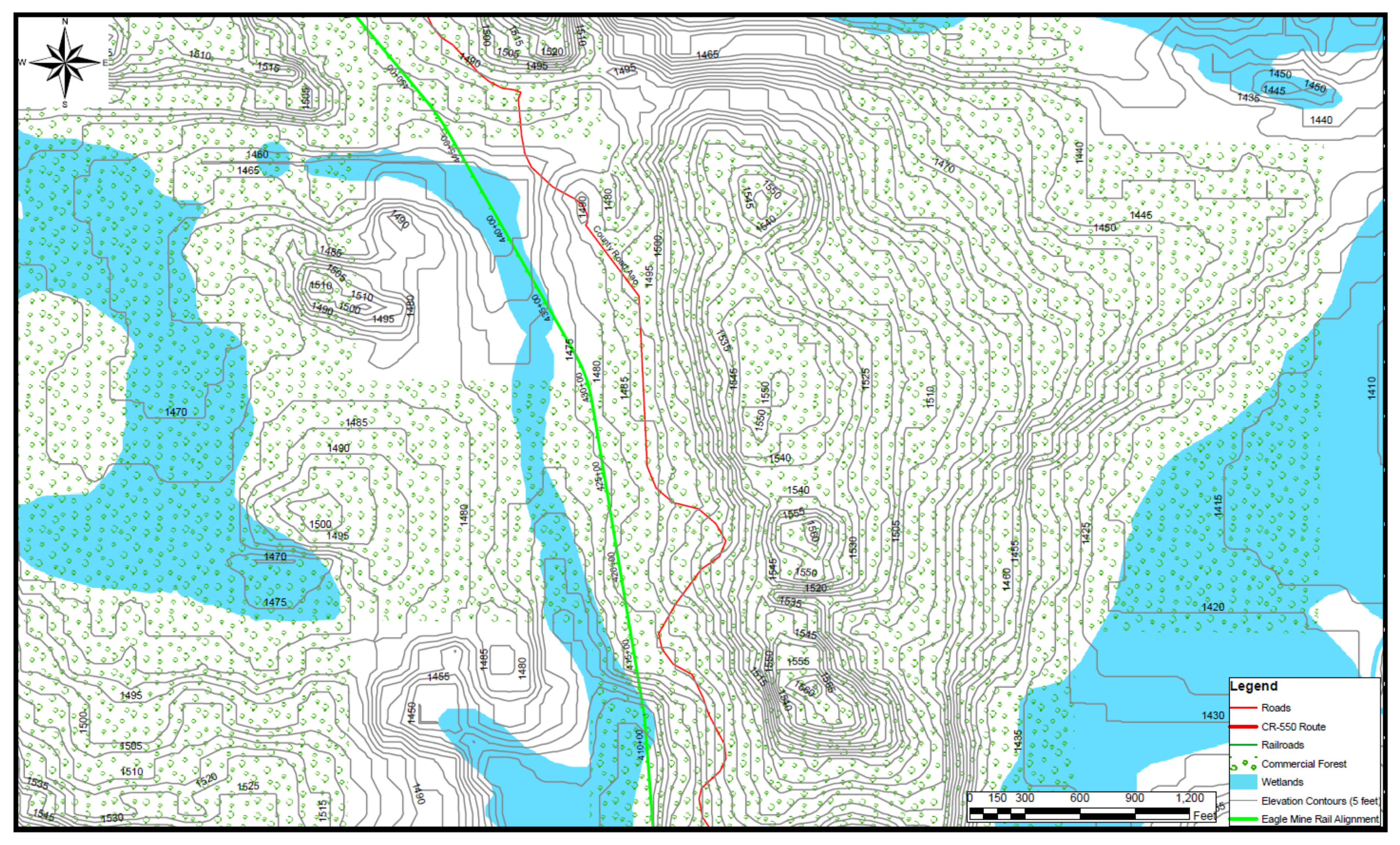




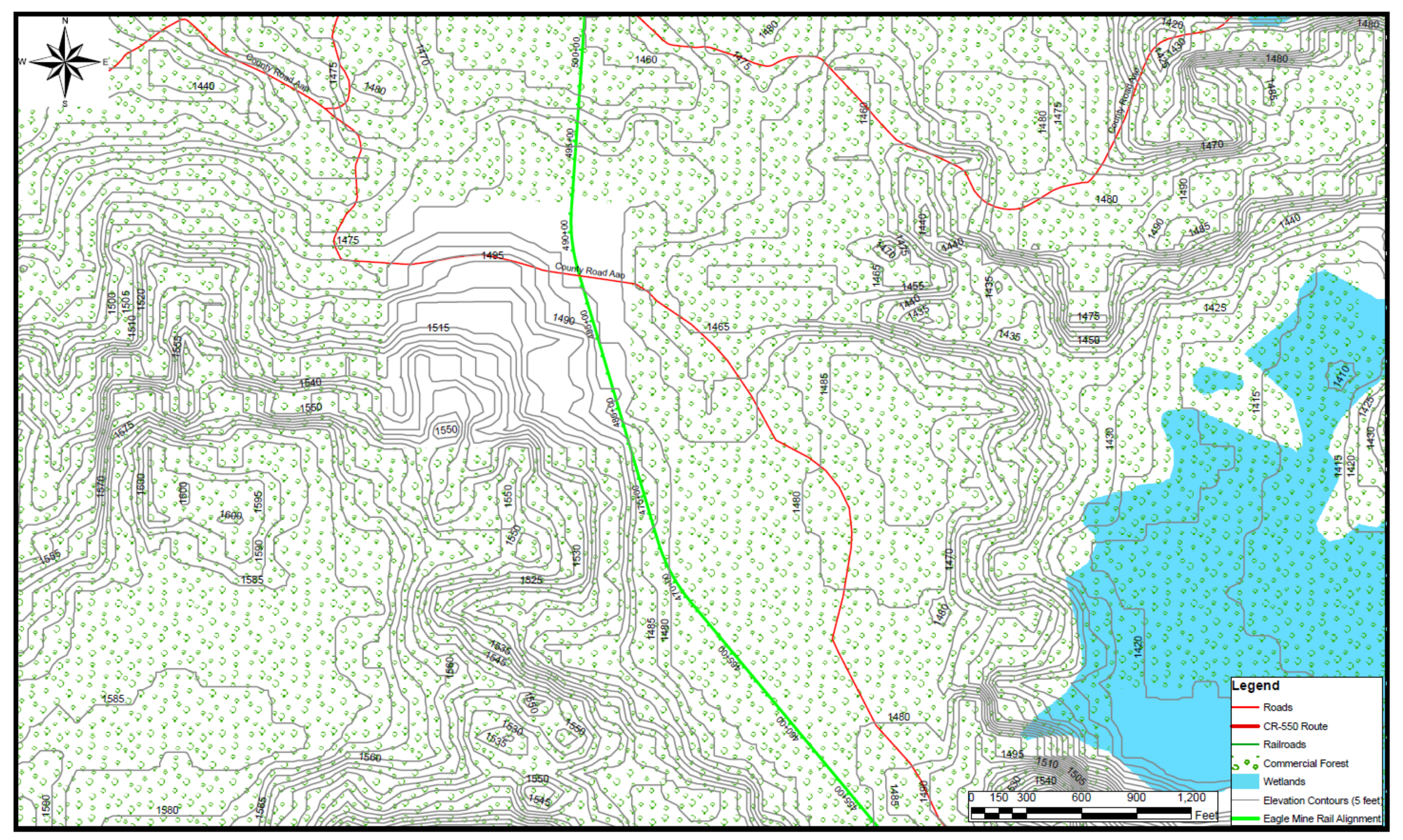




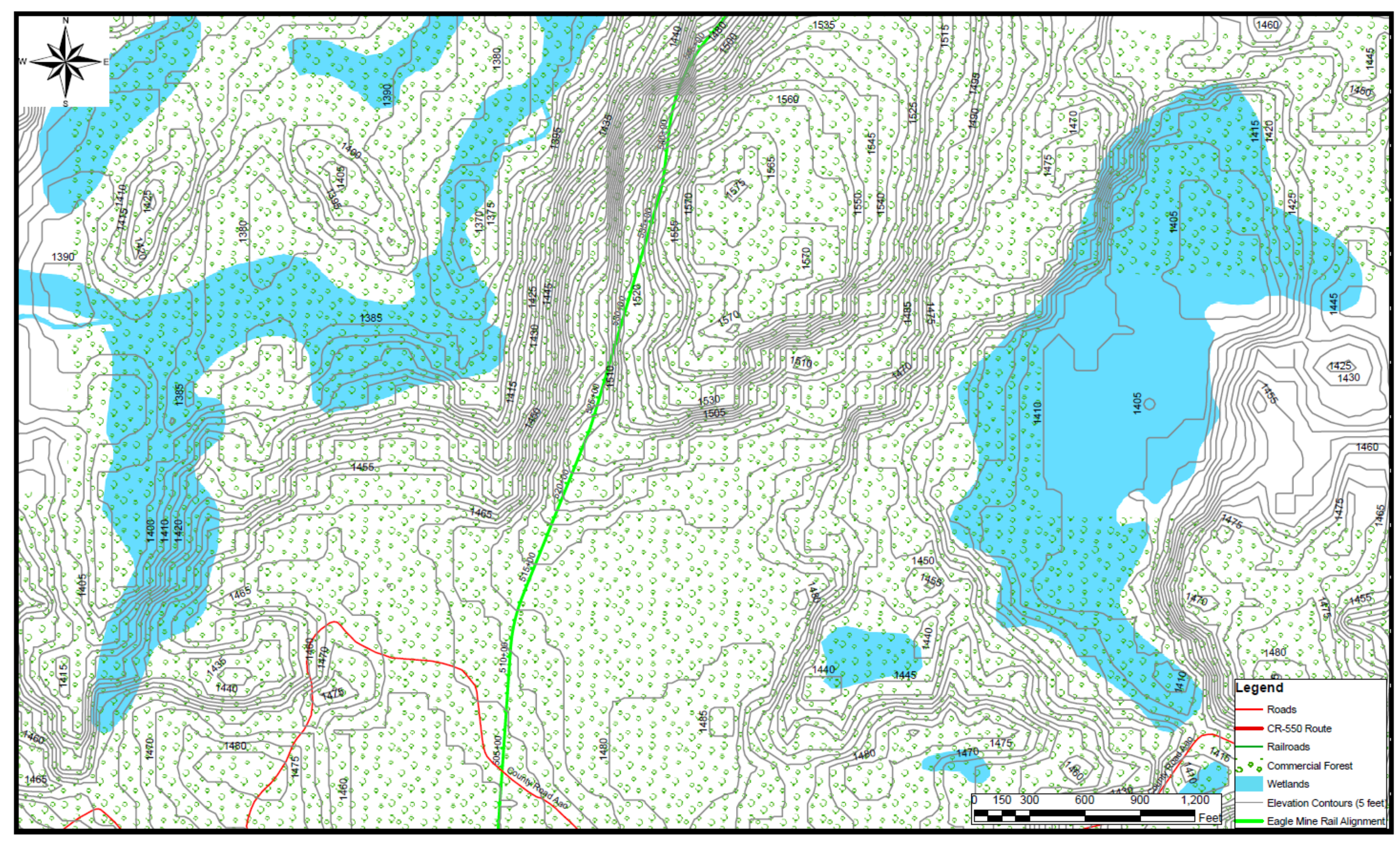




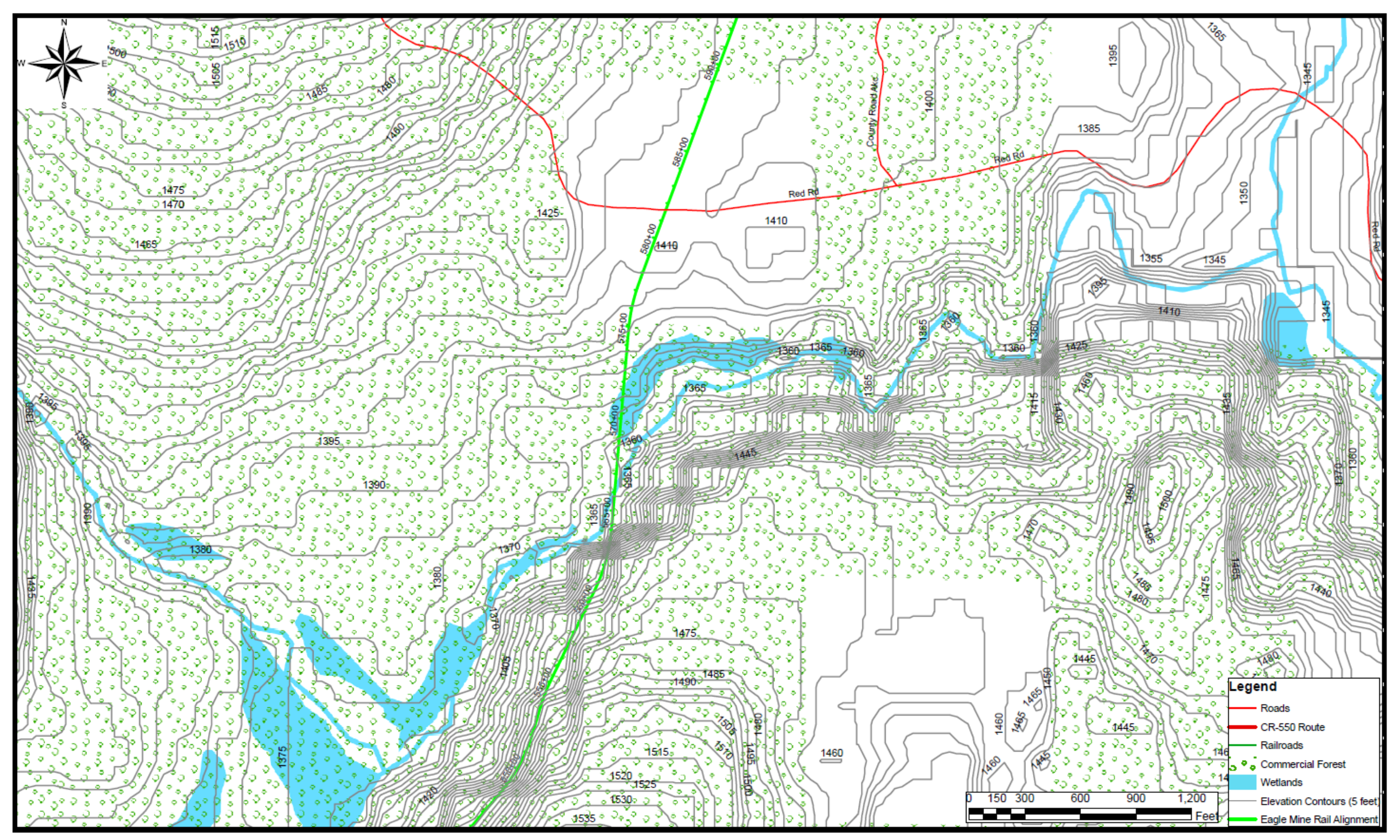




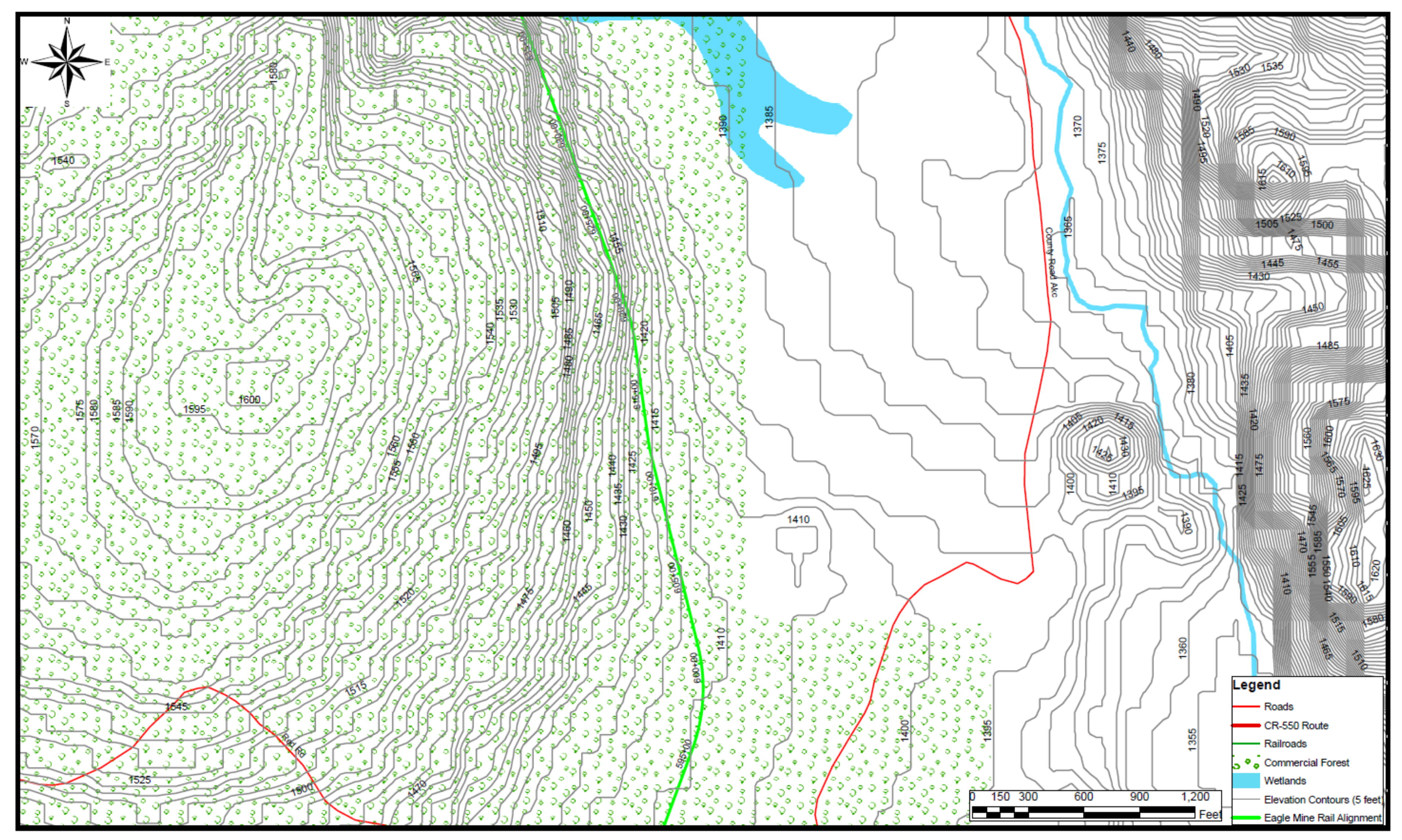




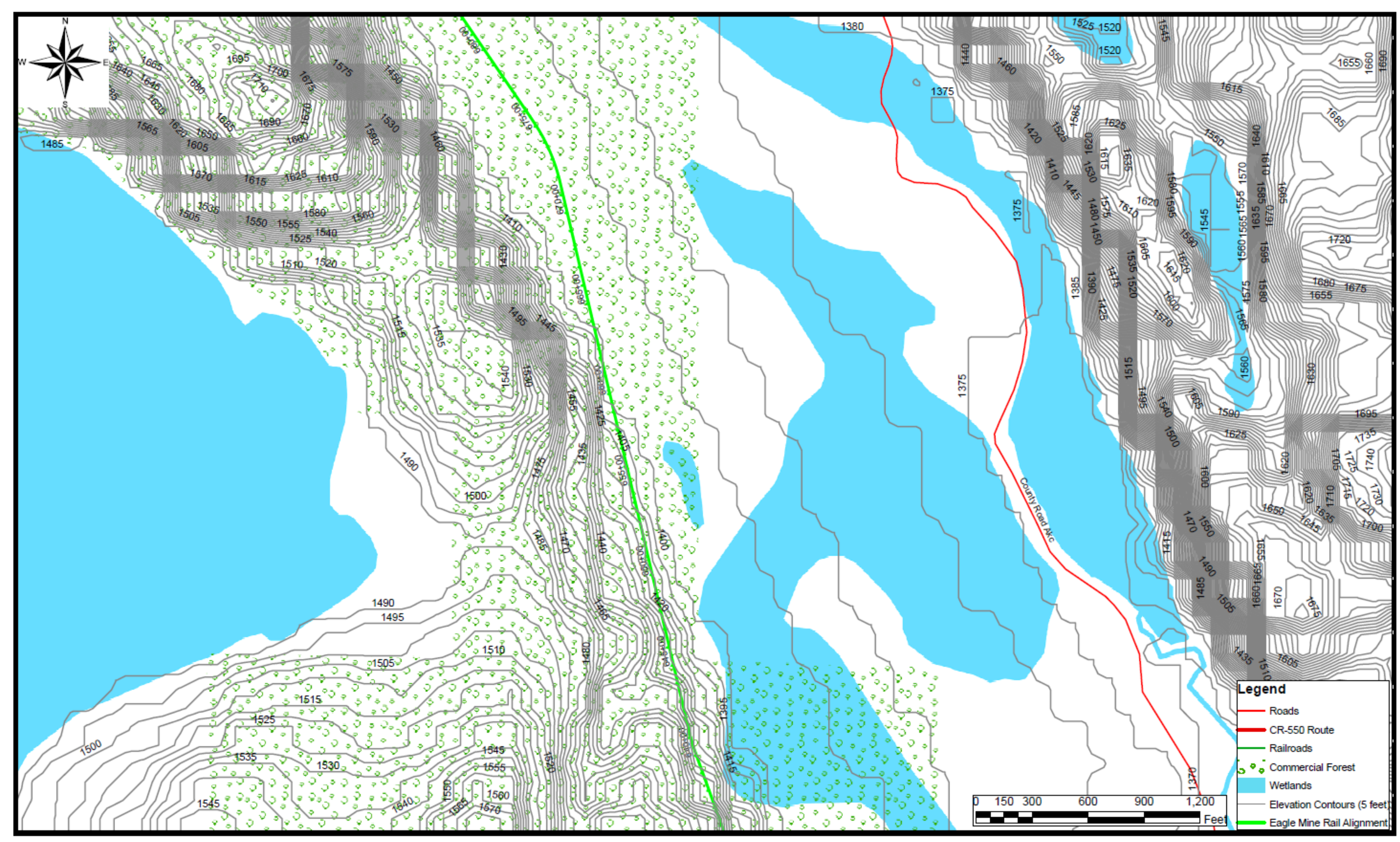




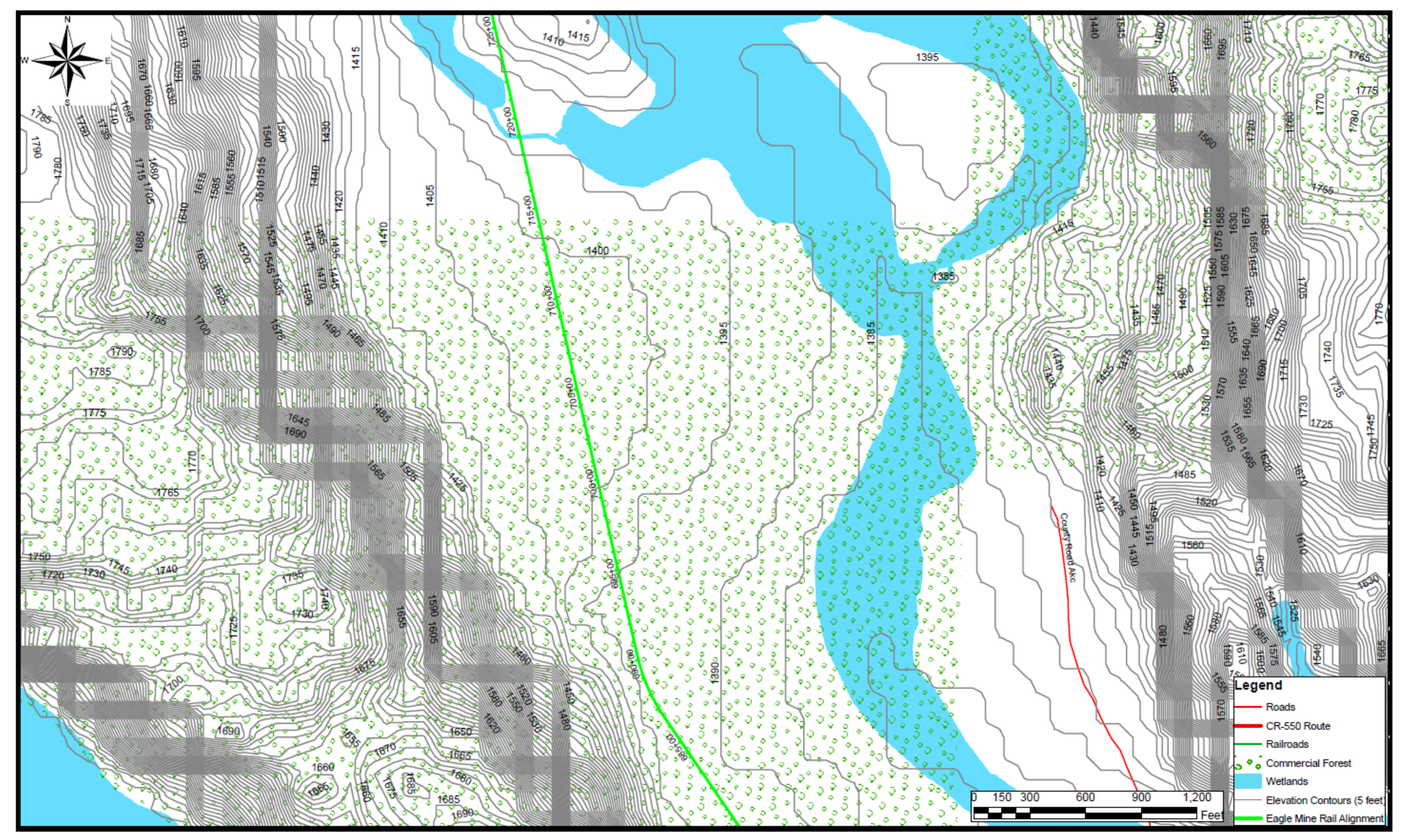




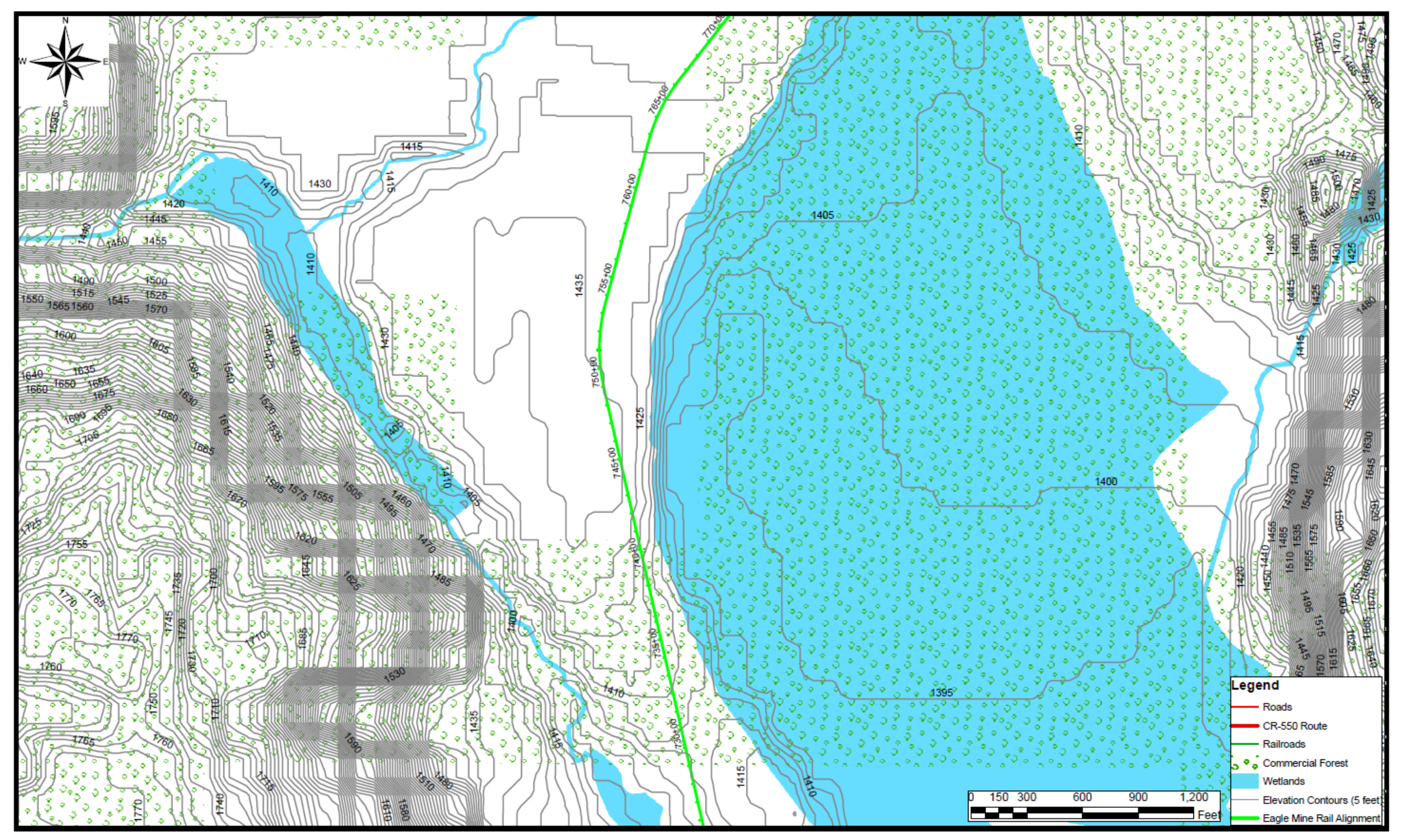




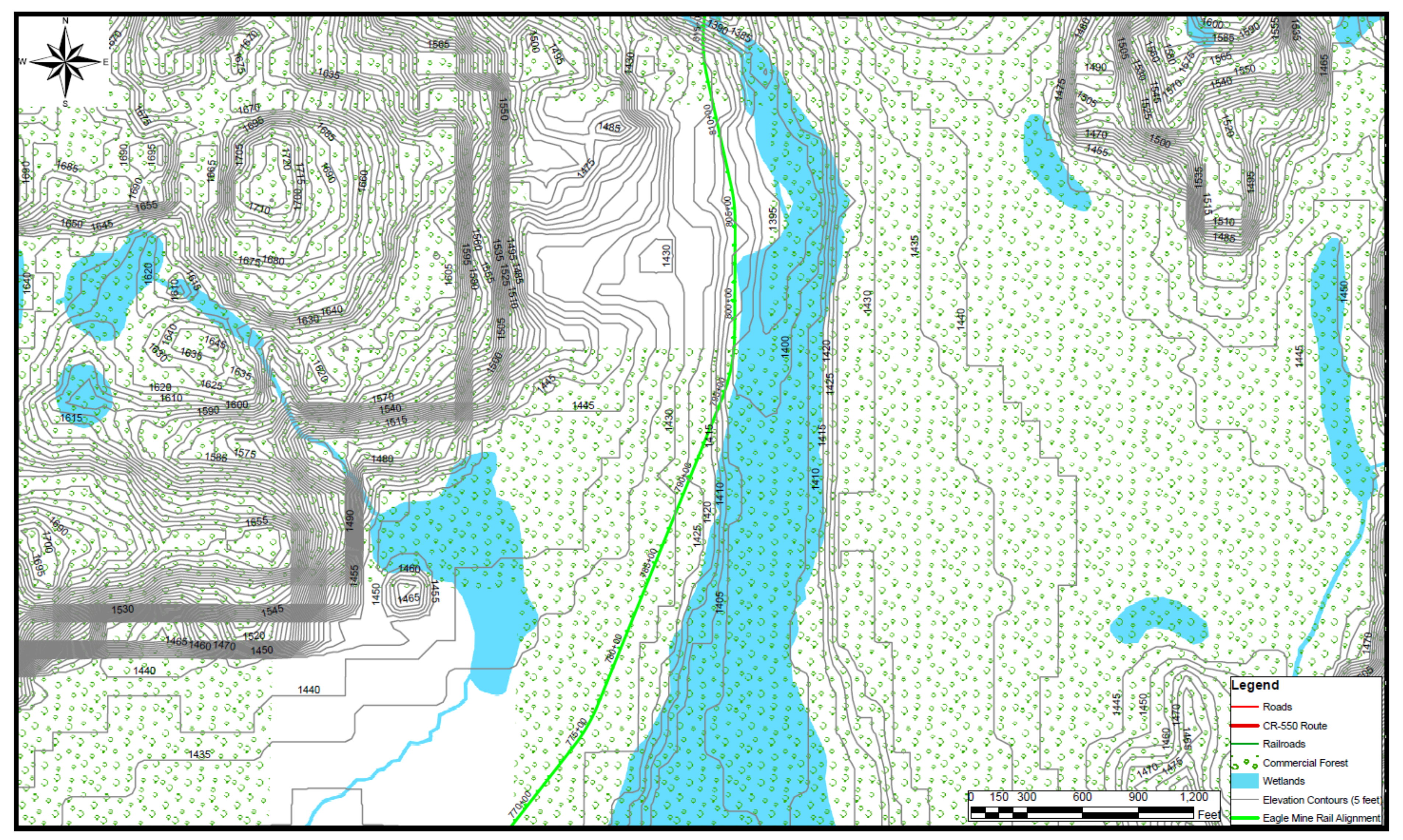




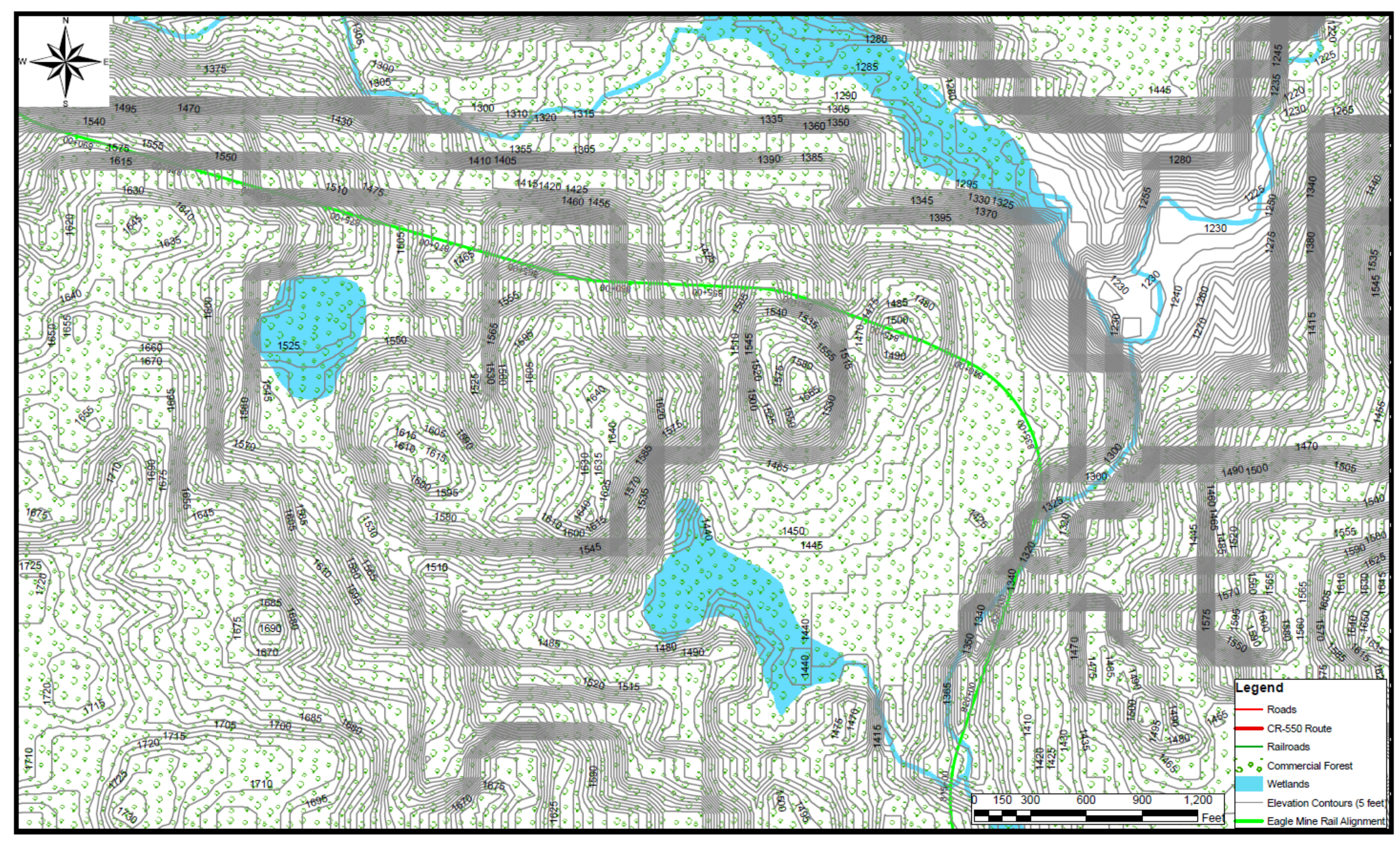




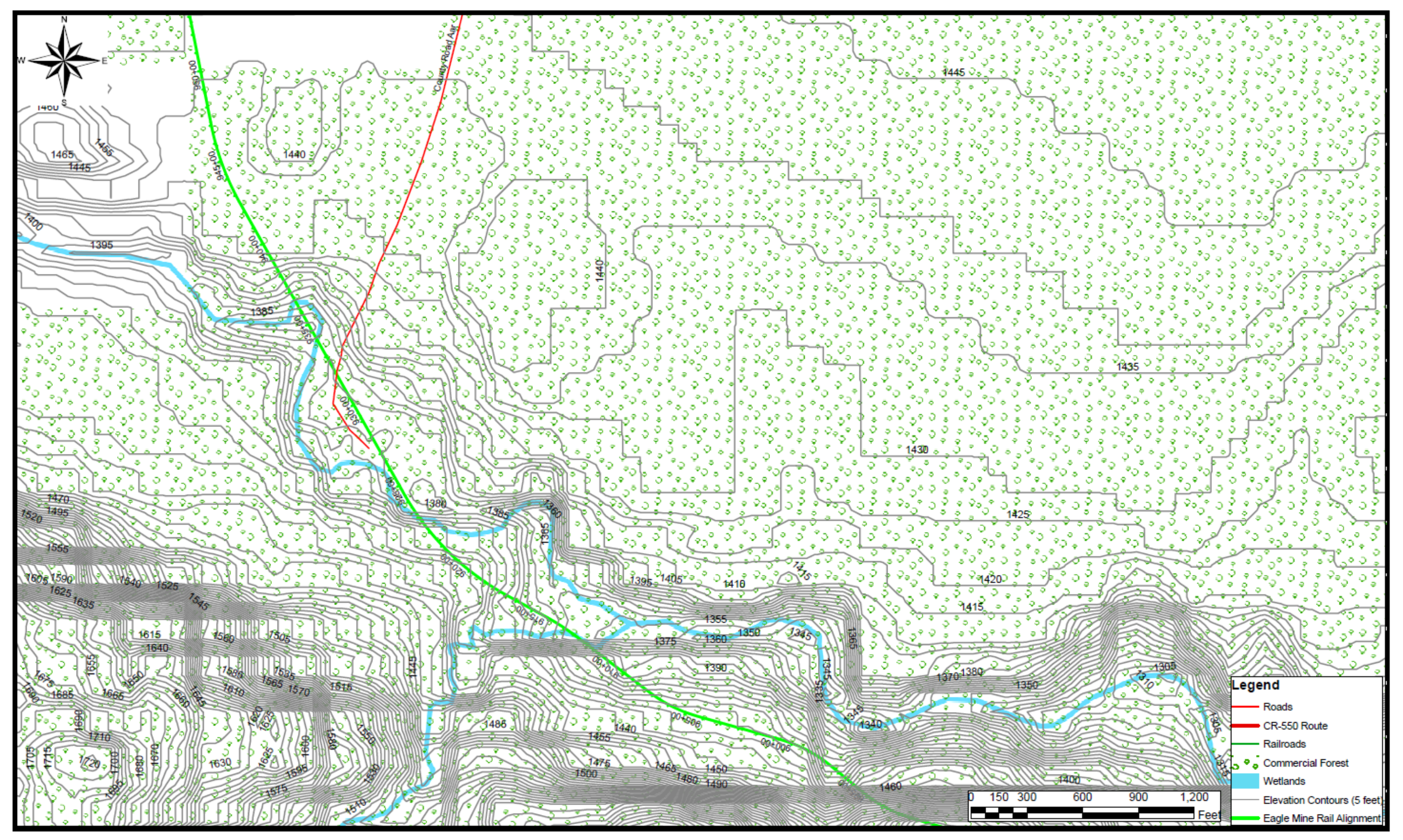




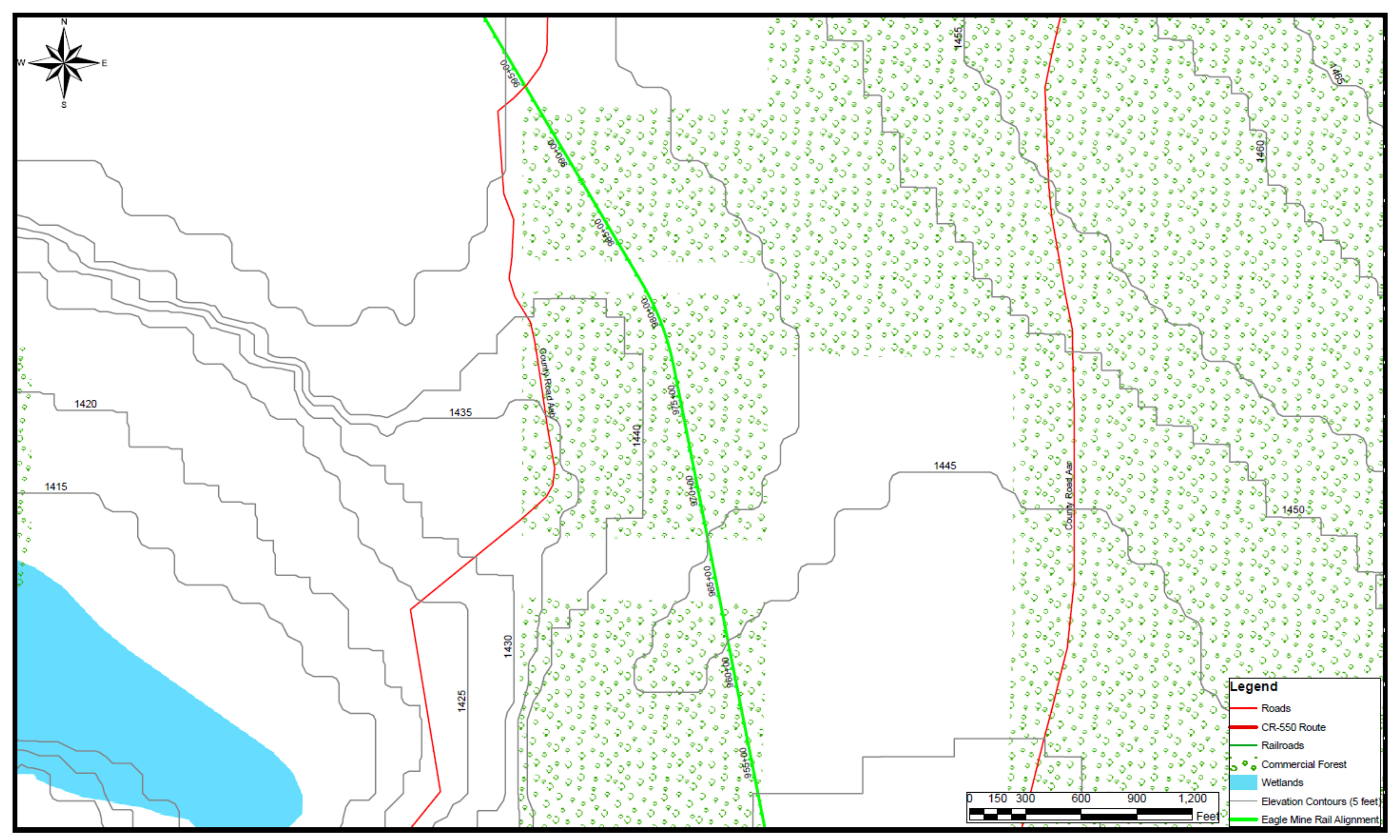




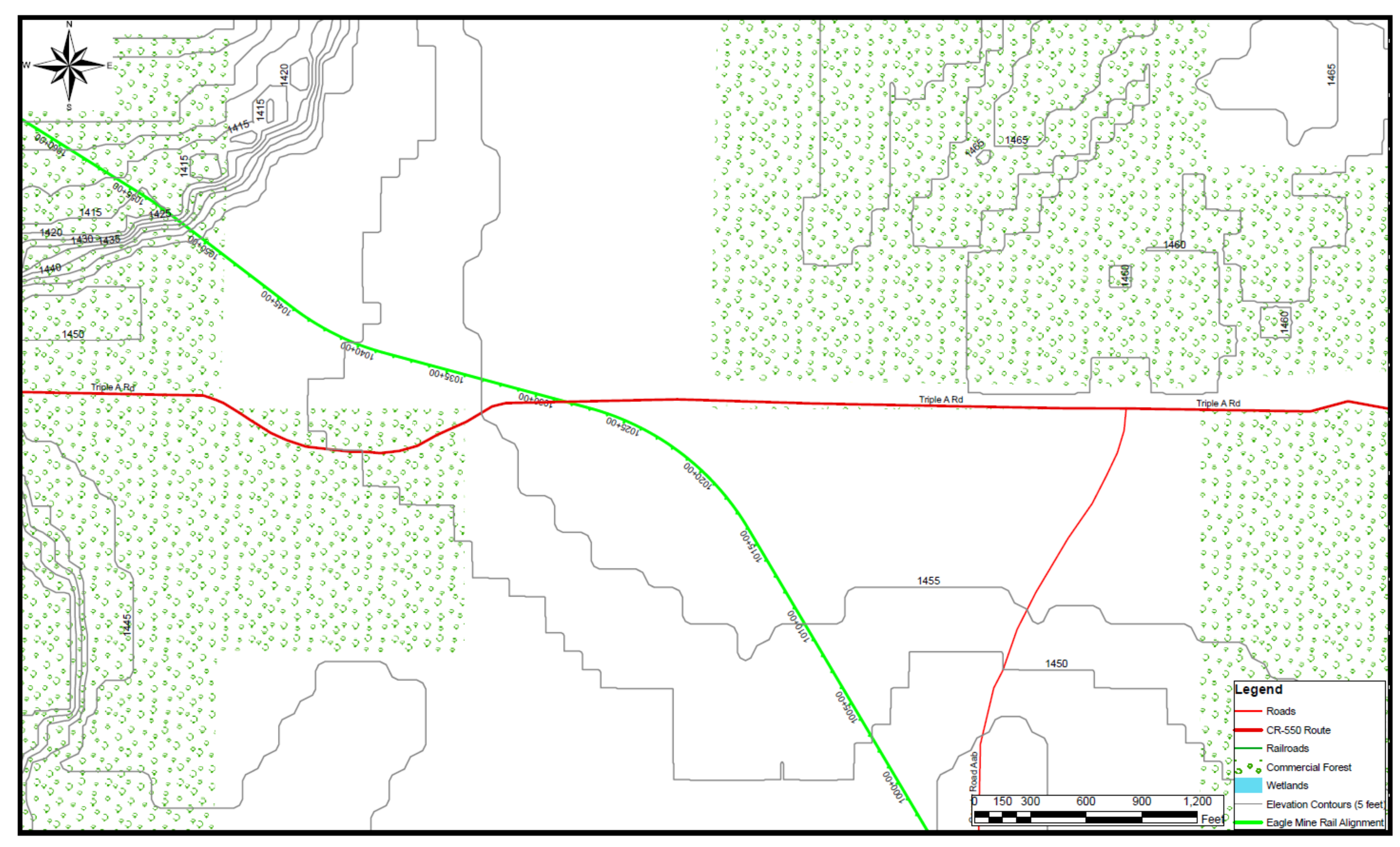




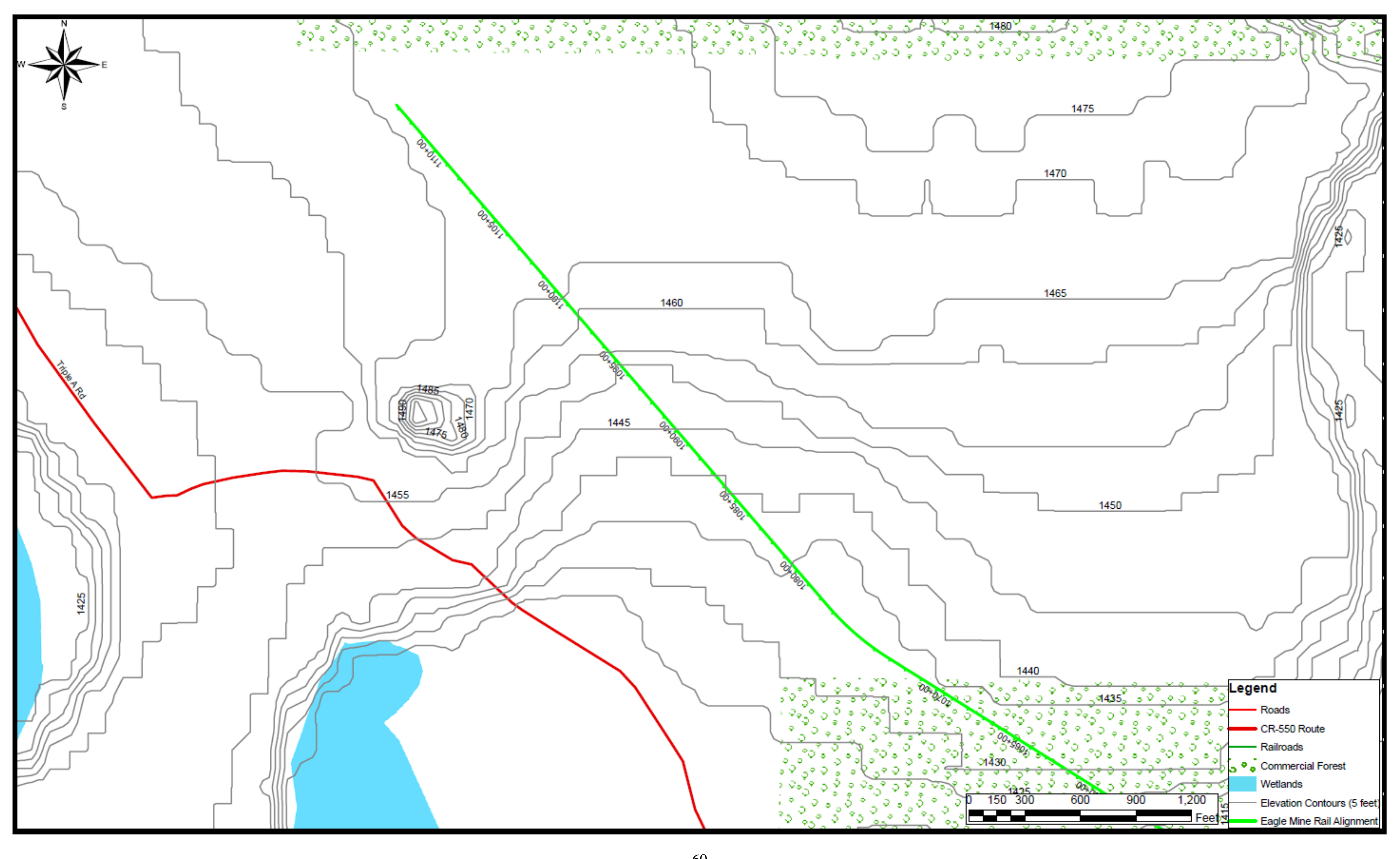




\section{Horizontal Curve Information Table}

\begin{tabular}{|c|c|c|c|c|c|c|c|}
\hline $\begin{array}{l}\text { Curve } \\
\#\end{array}$ & $\begin{array}{l}\text { Degree of } \\
\text { Curvature } \\
\text { (degrees) }\end{array}$ & $\begin{array}{l}\text { Radius } \\
\text { (feet) }\end{array}$ & $\begin{array}{l}\text { Curve } \\
\text { Length } \\
\text { (feet) }\end{array}$ & $\begin{array}{l}\text { Actual } \\
\text { Super- } \\
\text { elevation } \\
\text { (inches) }\end{array}$ & $\begin{array}{l}\text { Length } \\
\text { of } \\
\text { Spirals } \\
\text { (feet) }\end{array}$ & $\begin{array}{l}\text { Begin } \\
\text { Station }\end{array}$ & $\begin{array}{l}\text { End } \\
\text { Station }\end{array}$ \\
\hline 1. & 6 & 955.37 & 411.5 & 1 & 62 & $3+04.50$ & $8+39.97$ \\
\hline 2. & 6 & 955.37 & 292.85 & 1 & 62 & $17+22.34$ & $21+39.19$ \\
\hline 3. & 8 & 716.78 & 392.50 & 2 & 124 & $31+96.51$ & $38+37.00$ \\
\hline 4. & 8 & 716.78 & 190.00 & 2 & 124 & $62+62.54$ & $67+00.63$ \\
\hline 5. & 8 & 716.78 & 50.00 & 2 & 124 & $79+80.40$ & $82+76.58$ \\
\hline 6. & 4 & 1432.69 & 577.94 & 0.5 & 31 & $91+87.27$ & $98+27.20$ \\
\hline 7. & 4 & 1432.69 & 188.13 & 0.5 & 31 & $119+67.19$ & $122+17.31$ \\
\hline 8. & 4 & 1432.69 & 789.95 & 0.5 & 31 & $130+07.38$ & $138+59.33$ \\
\hline 9. & 4 & 1432.69 & 108.08 & 0.5 & 31 & $143+87.82$ & $145+26.90$ \\
\hline 10. & 6 & 955.37 & 255.03 & 1 & 62 & $155+38.81$ & $159+17.84$ \\
\hline 11. & 6 & 955.37 & 81.67 & 1 & 62 & $174+70.26$ & $176+75.92$ \\
\hline 12. & 6 & 955.37 & 163.72 & 1 & 62 & $184+42.50$ & $187+30.22$ \\
\hline 13. & 4 & 1432.69 & 141.14 & 0.5 & 31 & $194+94.58$ & $196+97.73$ \\
\hline 14. & 4 & 1432.69 & 198.42 & 0.5 & 31 & $201+22.76$ & $203+83.18$ \\
\hline 15. & 8 & 716.78 & 168.00 & 2 & 124 & $215+90.62$ & $220+06.62$ \\
\hline 16. & 6 & 955.37 & 170.80 & 1 & 62 & $222+91.93$ & $225+86.73$ \\
\hline 17. & 6 & 955.37 & 46.38 & 1 & 62 & $231+37.40$ & $223+07.78$ \\
\hline 18. & 6 & 955.37 & 223.69 & 1 & 62 & $236+10.20$ & $239+57.89$ \\
\hline 19. & 8 & 716.78 & 114.28 & 2 & 124 & $245+71.24$ & $249+33.52$ \\
\hline 20. & 8 & 716.78 & 197.92 & 2 & 124 & $257+09.75$ & $261+55.68$ \\
\hline 21. & 8 & 716.78 & 195.60 & 2 & 124 & $271+88.00$ & $276+31.58$ \\
\hline 22. & 8 & 716.78 & 203.23 & 2 & 124 & $299+35.66$ & $303+86.88$ \\
\hline 23. & 8 & 716.78 & 396.61 & 2 & 124 & $316+89.75$ & $323+34.37$ \\
\hline
\end{tabular}




\begin{tabular}{|l|l|l|l|l|l|l|l|}
\hline 24. & 8 & 716.78 & 147.33 & 2 & 124 & $369+98.10$ & $373+93.43$ \\
\hline $\mathbf{2 5 .}$ & 8 & 716.78 & 27.08 & 2 & 124 & $389+87.33$ & $392+62.42$ \\
\hline $\mathbf{2 6 .}$ & 8 & 716.78 & 130.27 & 2 & 124 & $427+66.47$ & $431+44.74$ \\
\hline $\mathbf{2 7 .}$ & 4 & 1432.69 & 217.84 & 0.5 & 31 & $444+53.22$ & $447+33.06$ \\
\hline $\mathbf{2 8 .}$ & 6 & 955.37 & 326.91 & 1 & 62 & $467+45.93$ & $471+96.64$ \\
\hline $\mathbf{2 9 .}$ & 6 & 955.37 & 278.74 & 1 & 62 & $486+70.67$ & $490+73.41$ \\
\hline $\mathbf{3 0 .}$ & 6 & 955.37 & 239.23 & 1 & 62 & $509+30.41$ & $512+93.64$ \\
\hline $\mathbf{3 1 .}$ & 6 & 955.37 & 28.65 & 1 & 62 & $521+68.92$ & $523+21.57$ \\
\hline $\mathbf{3 2 .}$ & 6 & 955.37 & 99.05 & 1 & 62 & $535+17.98$ & $537+41.02$ \\
\hline $\mathbf{3 3 .}$ & 6 & 955.37 & $502+42$ & 1 & 62 & $539+12.82$ & $545+39.27$ \\
\hline $\mathbf{3 4 .}$ & 6 & 955.37 & 344.79 & 1 & 62 & $547+06.49$ & $551+13.29$ \\
\hline $\mathbf{3 5 .}$ & 6 & 955.37 & 98.40 & 1 & 62 & $552+38.57$ & $554+60.98$ \\
\hline $\mathbf{3 6 .}$ & 6 & 955.37 & 289.51 & 1 & 62 & $559+37.75$ & $536+51.26$ \\
\hline $\mathbf{3 7 .}$ & 6 & 955.37 & 193.95 & 1 & 62 & $573+74.10$ & $576+92.04$ \\
\hline $\mathbf{3 8 .}$ & 6 & 955.37 & 506.11 & 1 & 62 & $594+11.64$ & $600+41.76$ \\
\hline $\mathbf{3 9 .}$ & 6 & 955.37 & 38.38 & 1 & 62 & $610+40.71$ & $612+03.09$ \\
\hline $\mathbf{4 0 .}$ & 6 & 955.37 & 139.24 & 1 & 62 & $616+67.53$ & $619+30.77$ \\
\hline $\mathbf{4 1 .}$ & 6 & 955.37 & 48.12 & 1 & 62 & 638.08 .77 & $639+80.83$ \\
\hline $\mathbf{4 2 .}$ & 6 & 955.37 & 291.41 & 1 & 62 & $669+59.54$ & $673+74.94$ \\
\hline $\mathbf{4 3 .}$ & 6 & 955.37 & 298.54 & 1 & 62 & $685+49.09$ & $689+71.63$ \\
\hline $\mathbf{4 4 .}$ & 6 & 955.37 & 401.62 & 1 & 62 & $747+81.11$ & $753+06.73$ \\
\hline $\mathbf{4 5 .}$ & 6 & 955.37 & 321.63 & 1 & 62 & $761+42.72$ & $765+88.36$ \\
\hline $\mathbf{4 6 .}$ & 6 & 955.37 & 203.00 & 1 & 62 & $772+98.60$ & $776+25.60$ \\
\hline $\mathbf{4 7 .}$ & 6 & 955.37 & 302.02 & 1 & 62 & $793+42.60$ & $797+68.62$ \\
\hline $\mathbf{4 8 .}$ & 6 & 955.37 & 151.18 & 1 & 62 & $803+00.58$ & $805+75.76$ \\
\hline $\mathbf{4 9 .}$ & 6 & 955.37 & 461.94 & 1 & 62 & $811+04.45$ & $816+90.36$ \\
\hline $\mathbf{5 0 .}$ & 8 & 716.78 & 928.29 & 1 & 124 & $828+35.29$ & $840+11.58$ \\
\hline $\mathbf{5 1 .}$ & 6 & 955.37 & 223.96 & 1 & 62 & $848+45.98$ & $851+97.93$ \\
\hline
\end{tabular}




\begin{tabular}{|l|l|l|l|l|l|l|l|}
\hline $\mathbf{5 2 .}$ & 6 & 955.37 & 151.51 & 1 & 62 & $859+44.50$ & $862+39.40$ \\
\hline $\mathbf{5 3 .}$ & 8 & 716.78 & 172.14 & 2 & 124 & $889+85.74$ & $894+05.88$ \\
\hline $\mathbf{5 4 .}$ & 8 & 716.78 & 175.93 & 2 & 124 & $895+14.18$ & $899+38.11$ \\
\hline $\mathbf{5 5 .}$ & 8 & 716.78 & 147.55 & 2 & 124 & $902+96.27$ & $906+91.82$ \\
\hline $\mathbf{5 6 .}$ & 4 & 1432.69 & 187.85 & 0.5 & 31 & $911+08.45$ & $913+58.30$ \\
\hline $\mathbf{5 7 .}$ & 4 & 1432.69 & 768.05 & 0.5 & 31 & $915+54.65$ & $923+84.70$ \\
\hline $\mathbf{5 8 .}$ & 4 & 1432.69 & 426.44 & 0.5 & 31 & $941+48.19$ & $946+36.62$ \\
\hline $\mathbf{5 9 .}$ & 4 & 1432.69 & 458.01 & 0.5 & 31 & $975+64.95$ & $980+84.96$ \\
\hline $\mathbf{6 0 .}$ & 4 & 1432.69 & 1074.92 & 0.5 & 31 & $1014+97.89$ & $1026+34.81$ \\
\hline $\mathbf{6 1 .}$ & 4 & 1432.69 & 524.43 & 0.5 & 31 & $1037+55.12$ & $1043+41.56$ \\
\hline $\mathbf{6 2 .}$ & 4 & 1432.69 & 101.06 & 0.5 & 31 & $1051+79.24$ & $1053+42.29$ \\
\hline $\mathbf{6 3 .}$ & 4 & 1432.69 & 399.77 & 0.5 & 31 & $1072+13.55$ & $1076+75.32$ \\
\hline
\end{tabular}



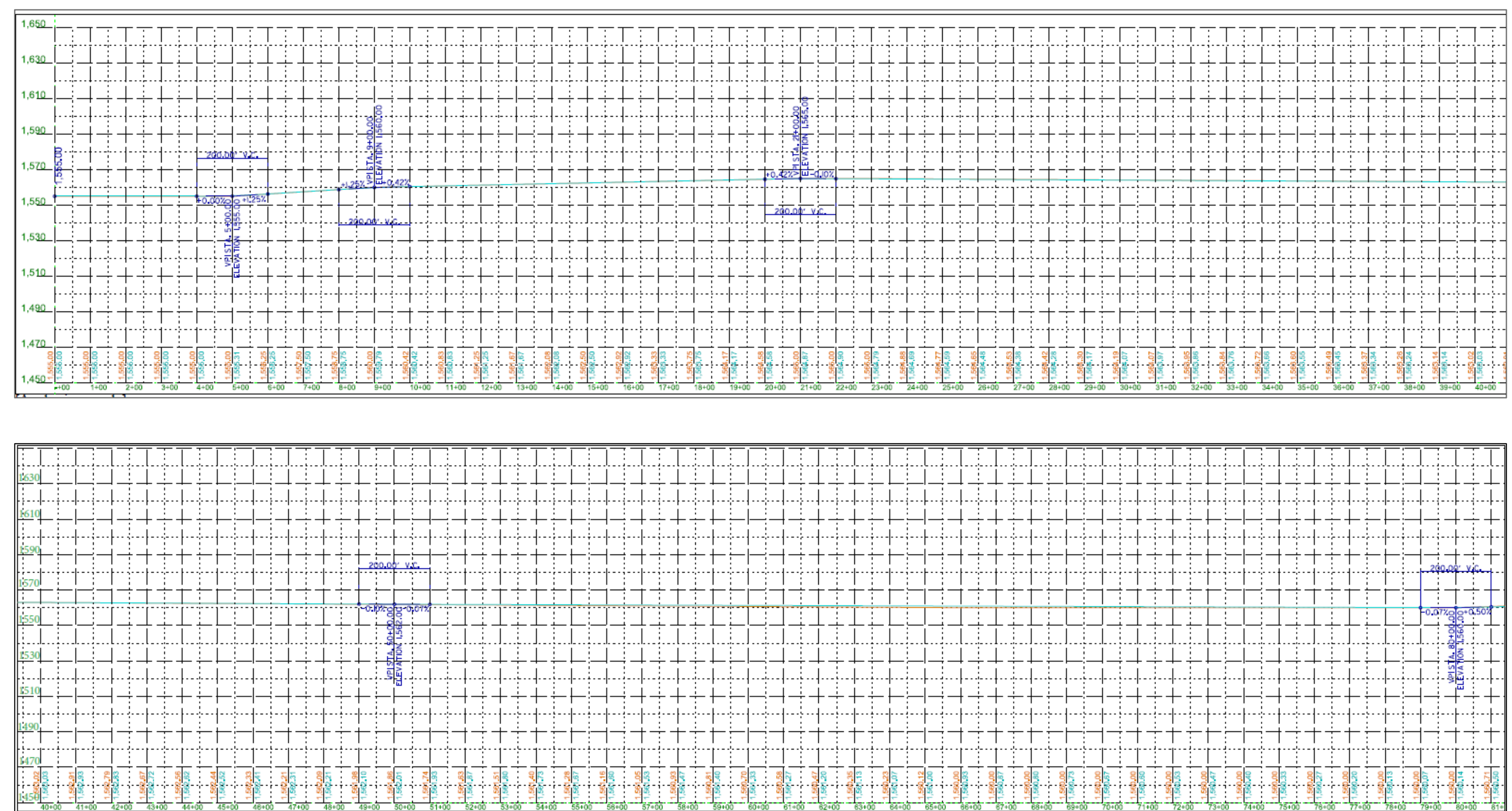

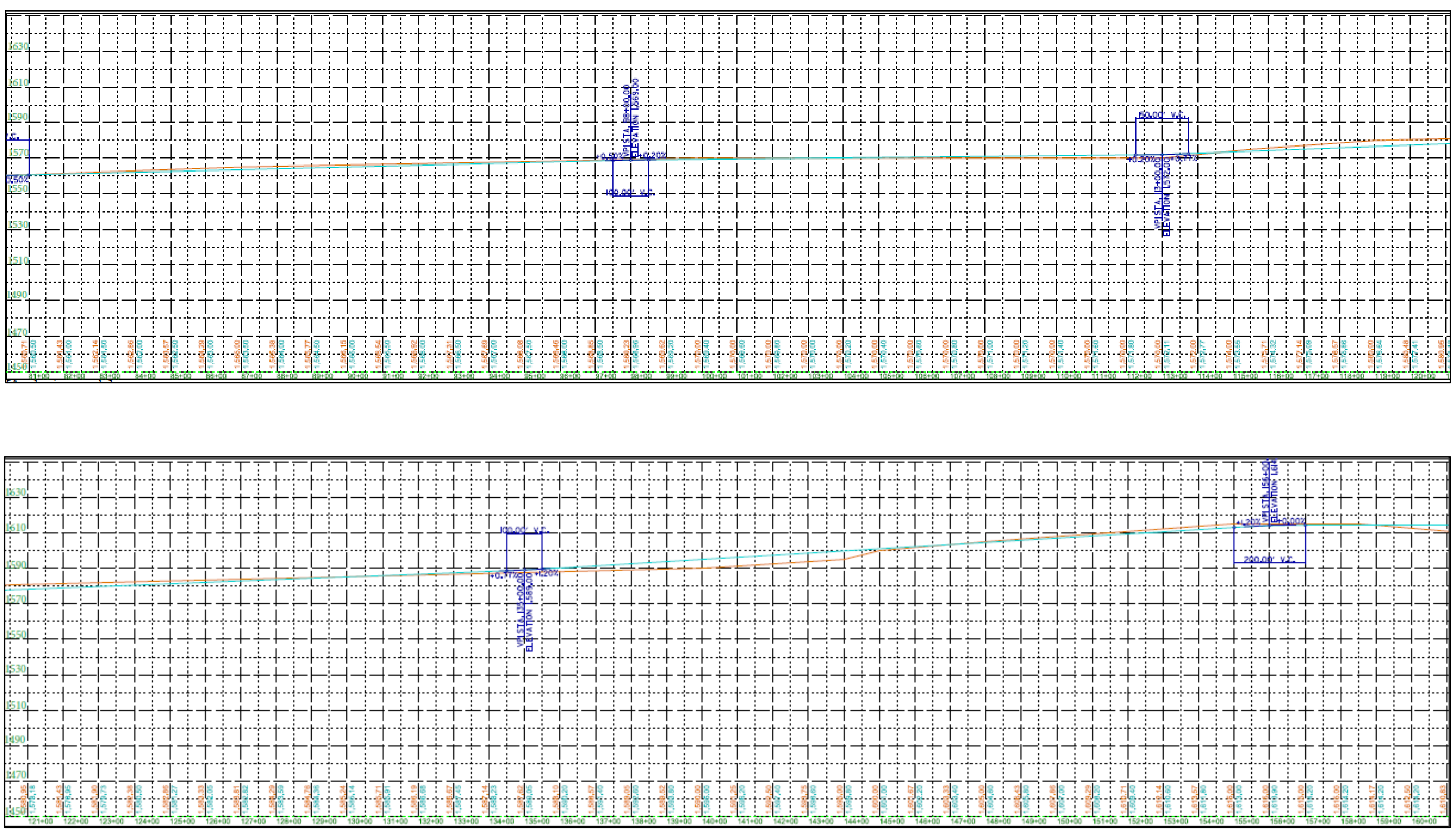

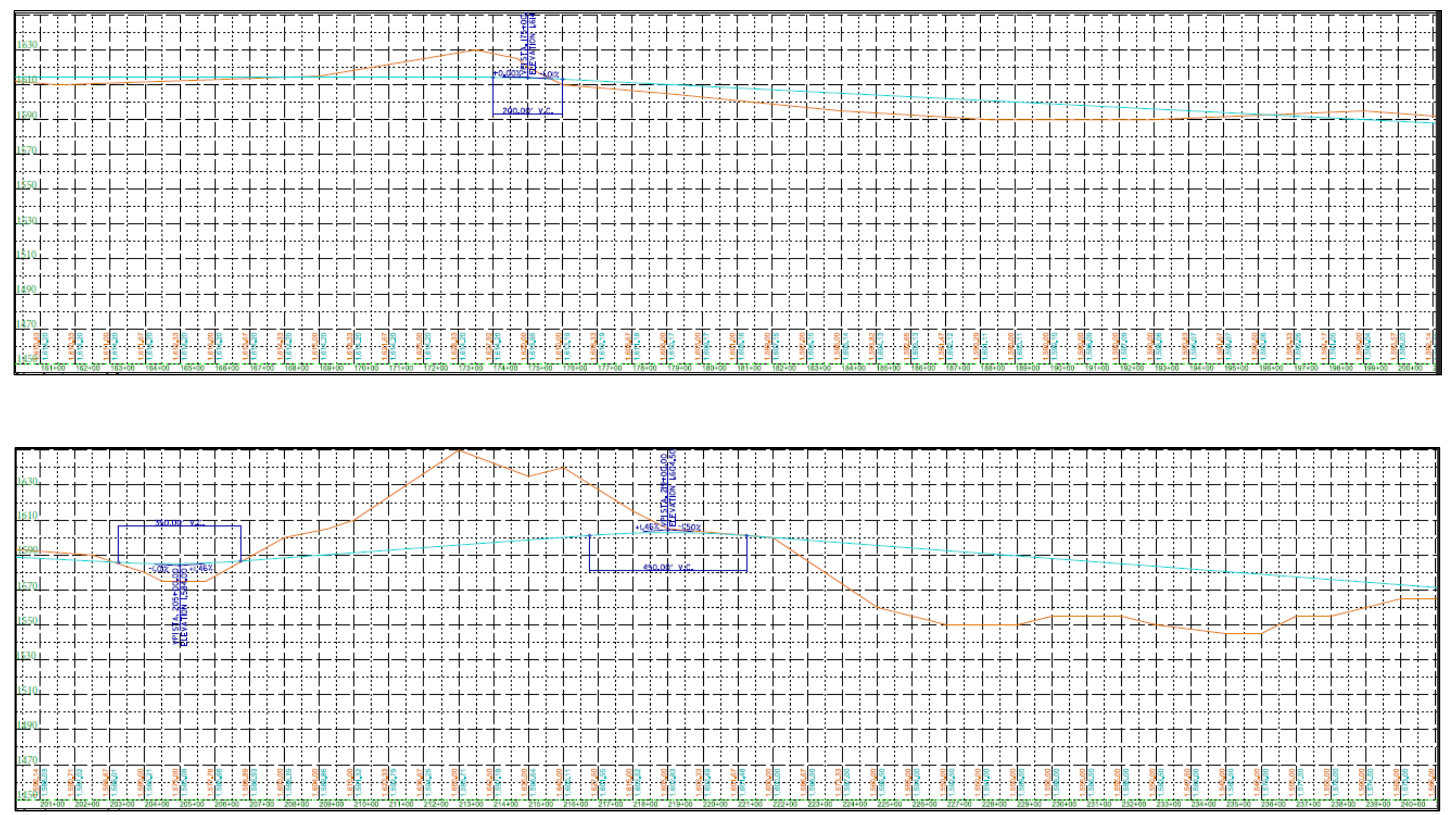

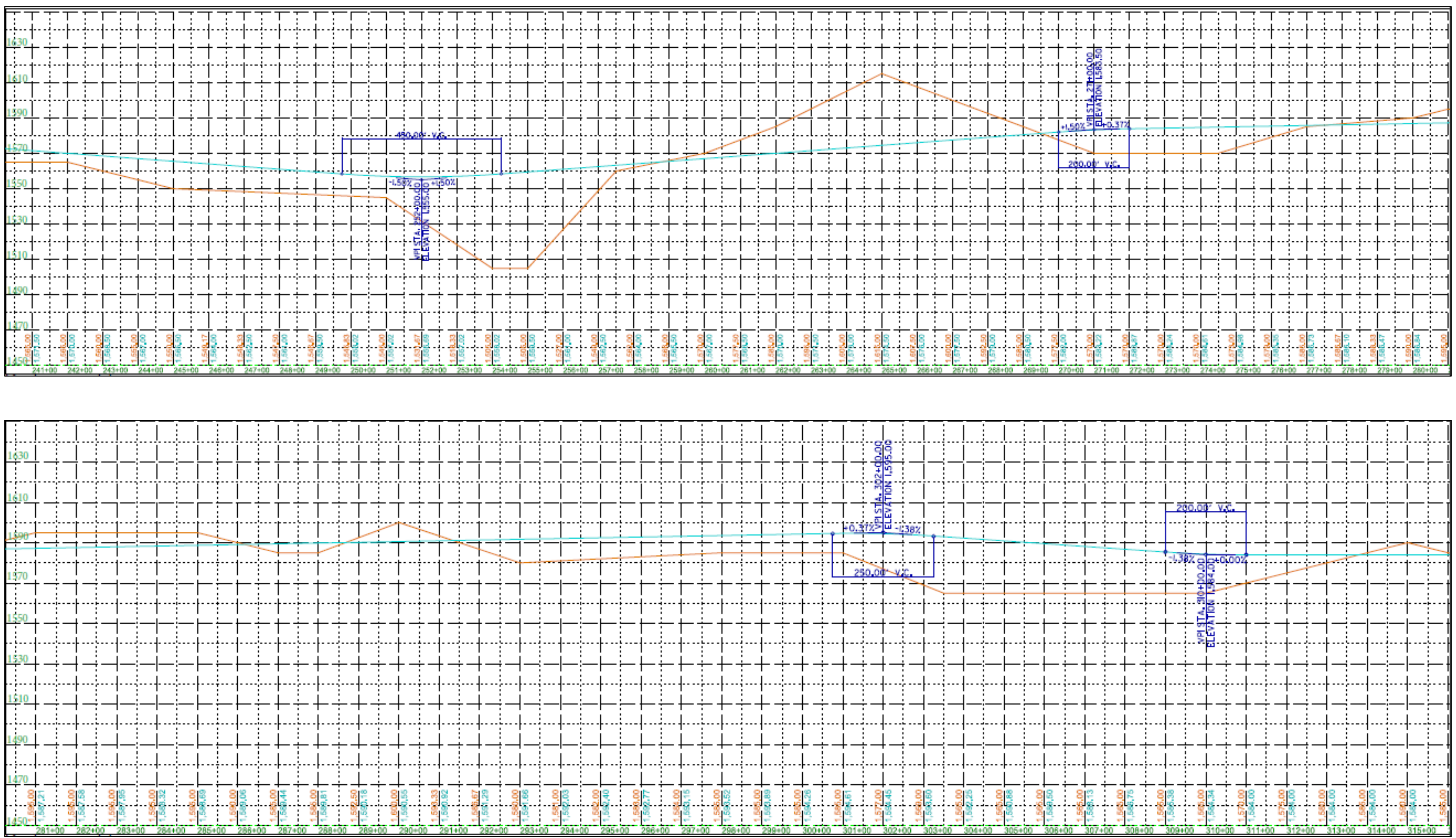


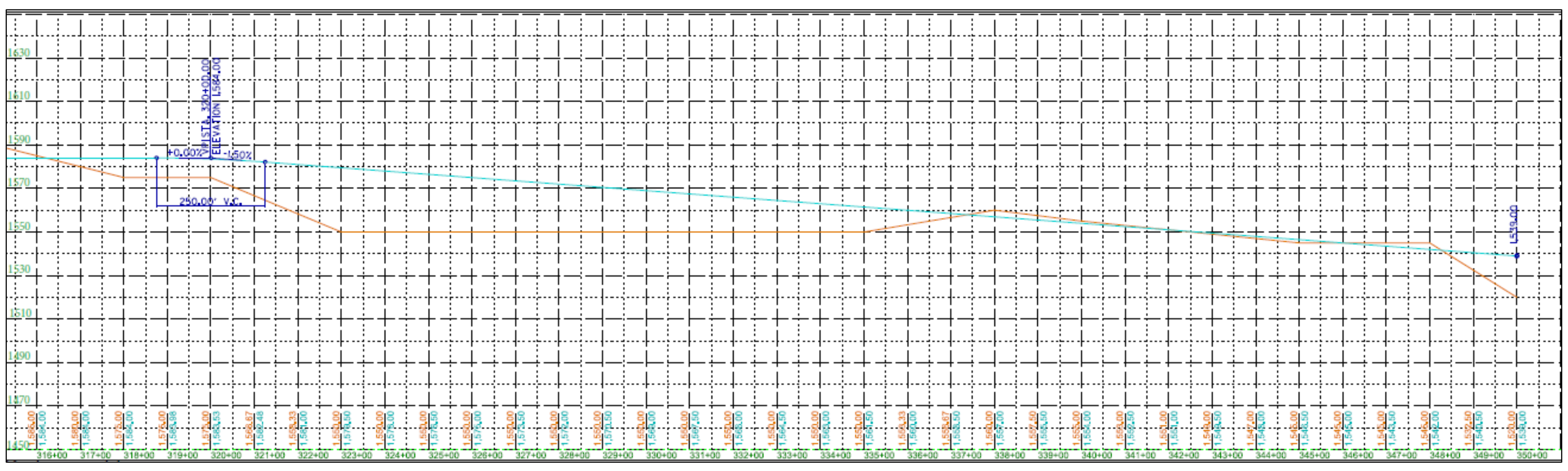

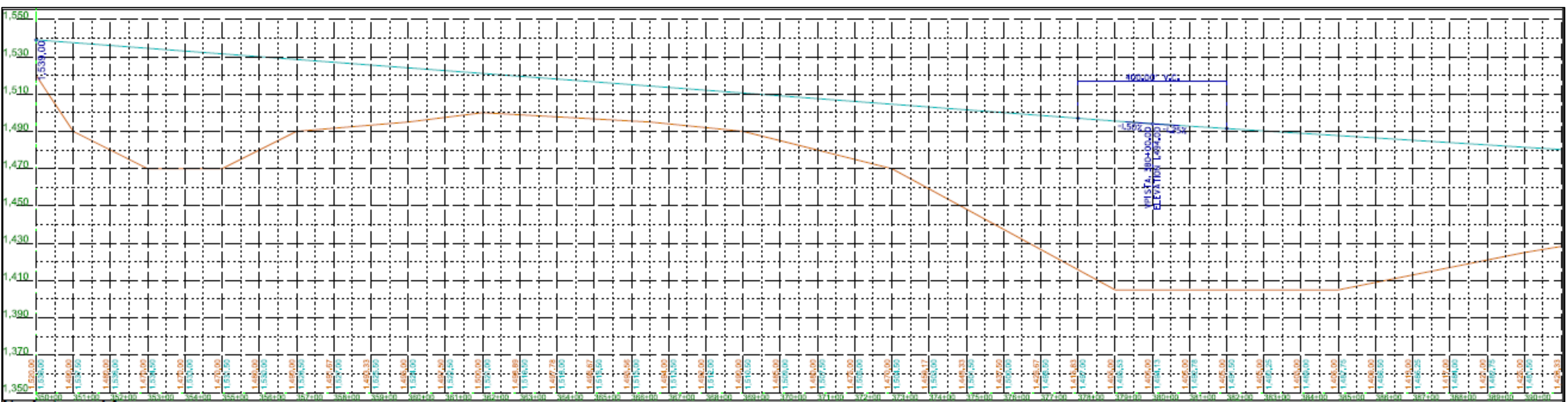



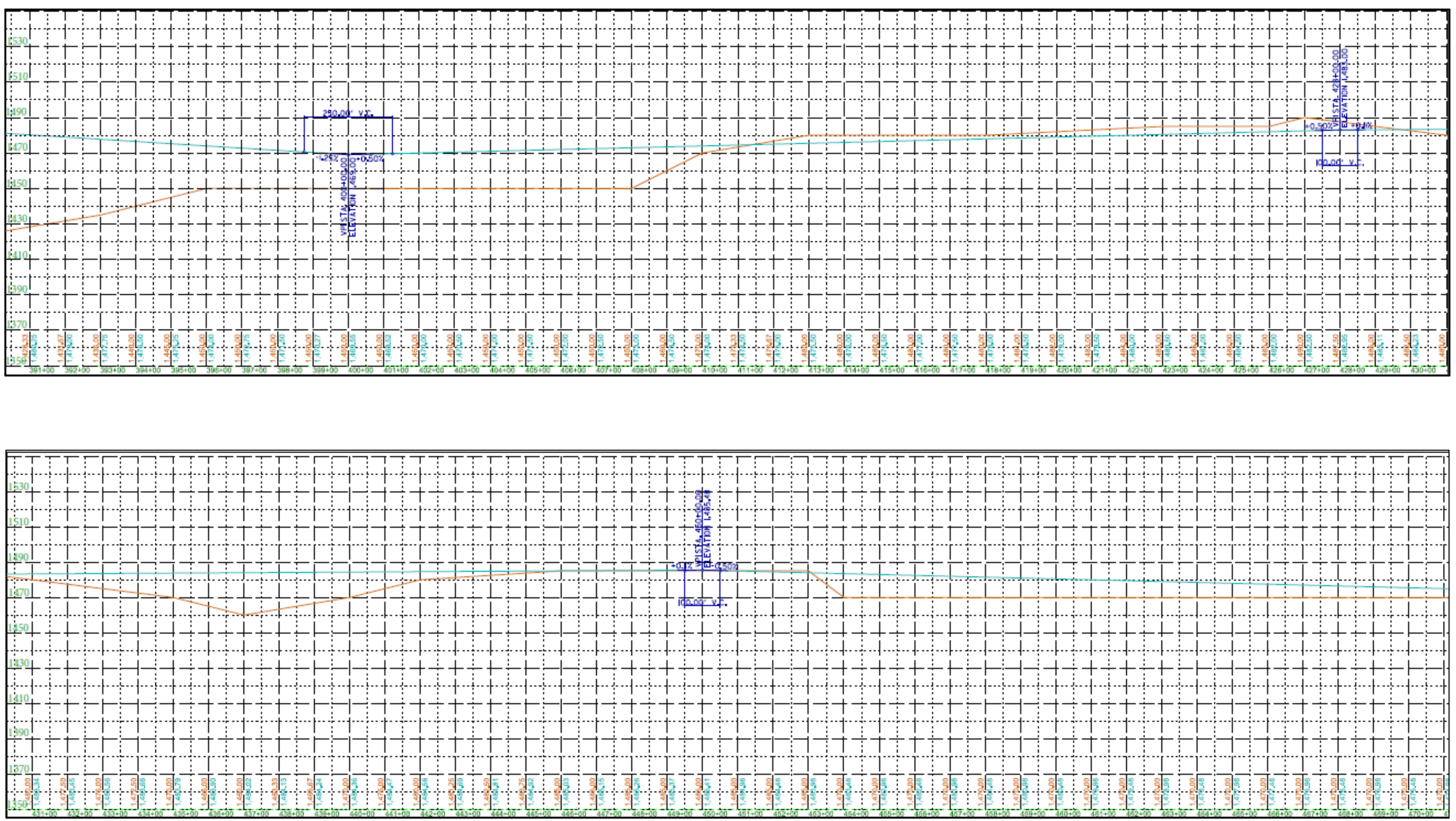

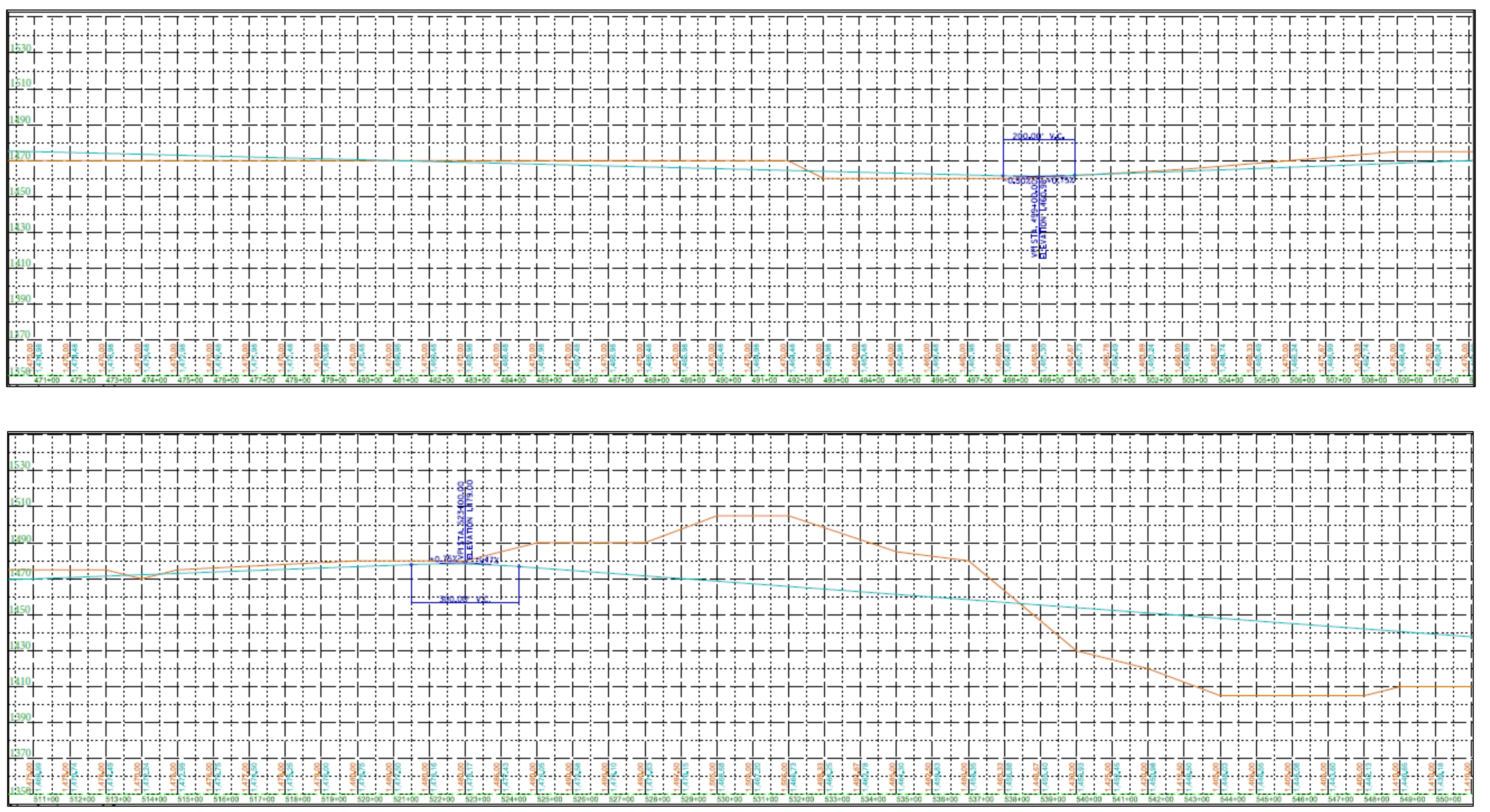

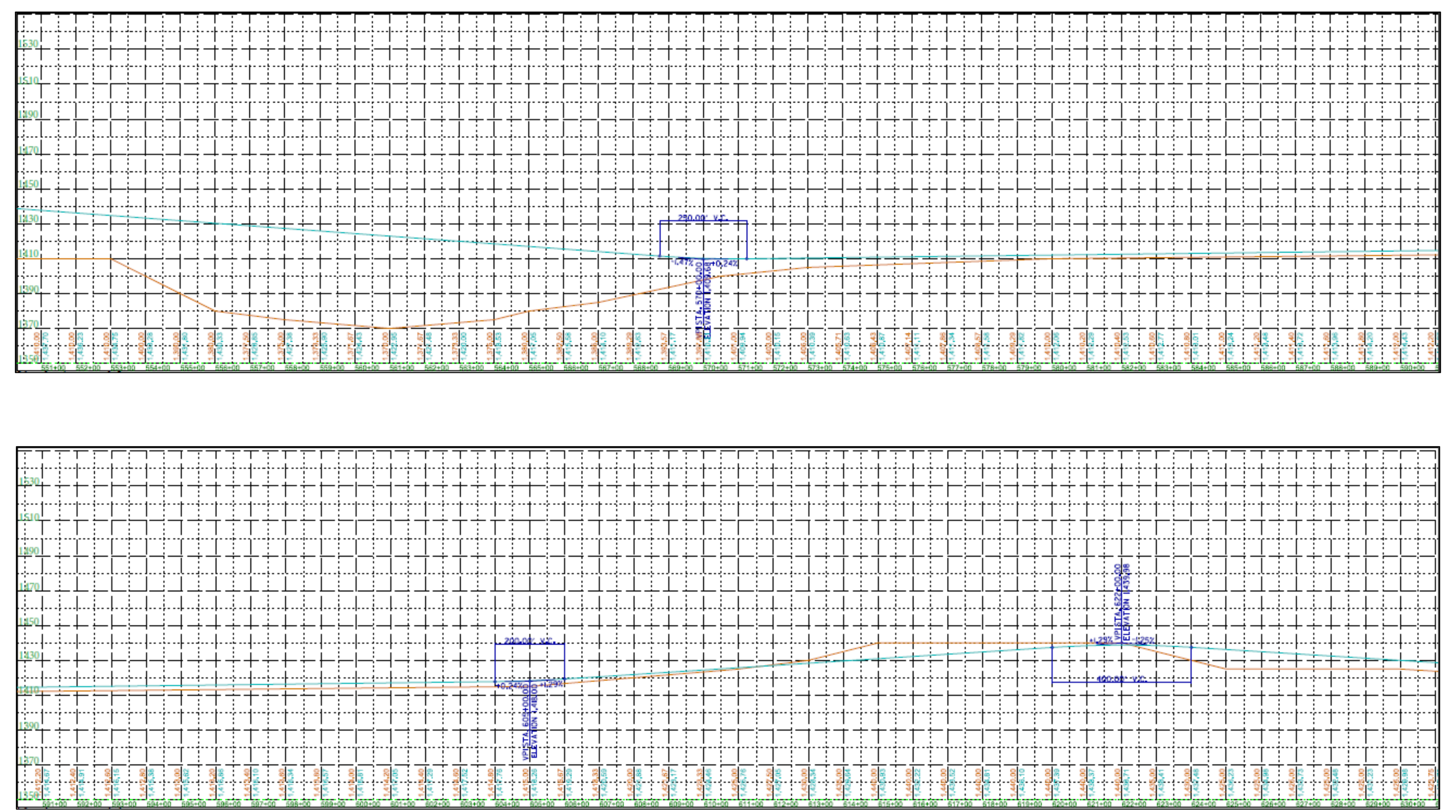

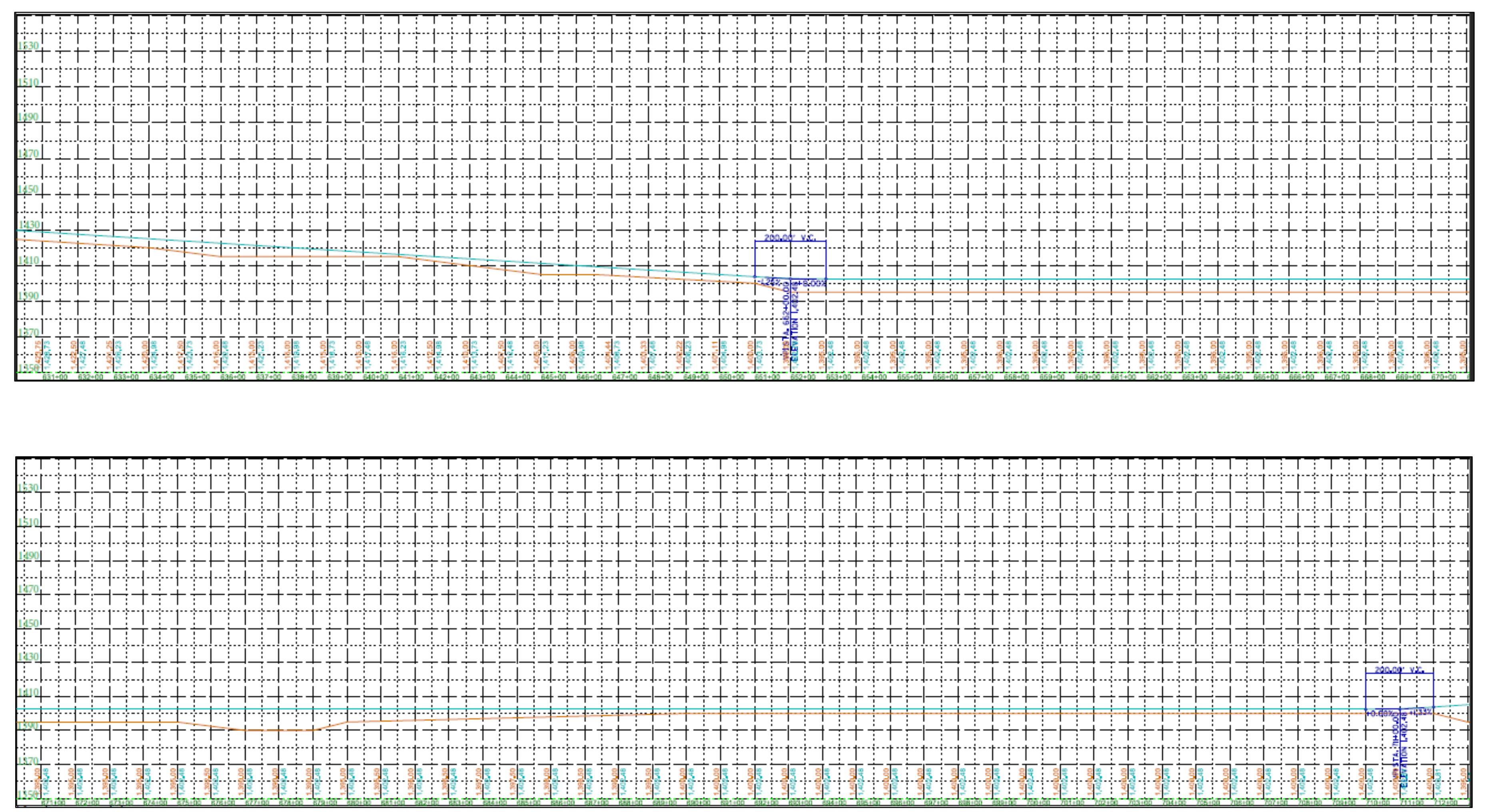

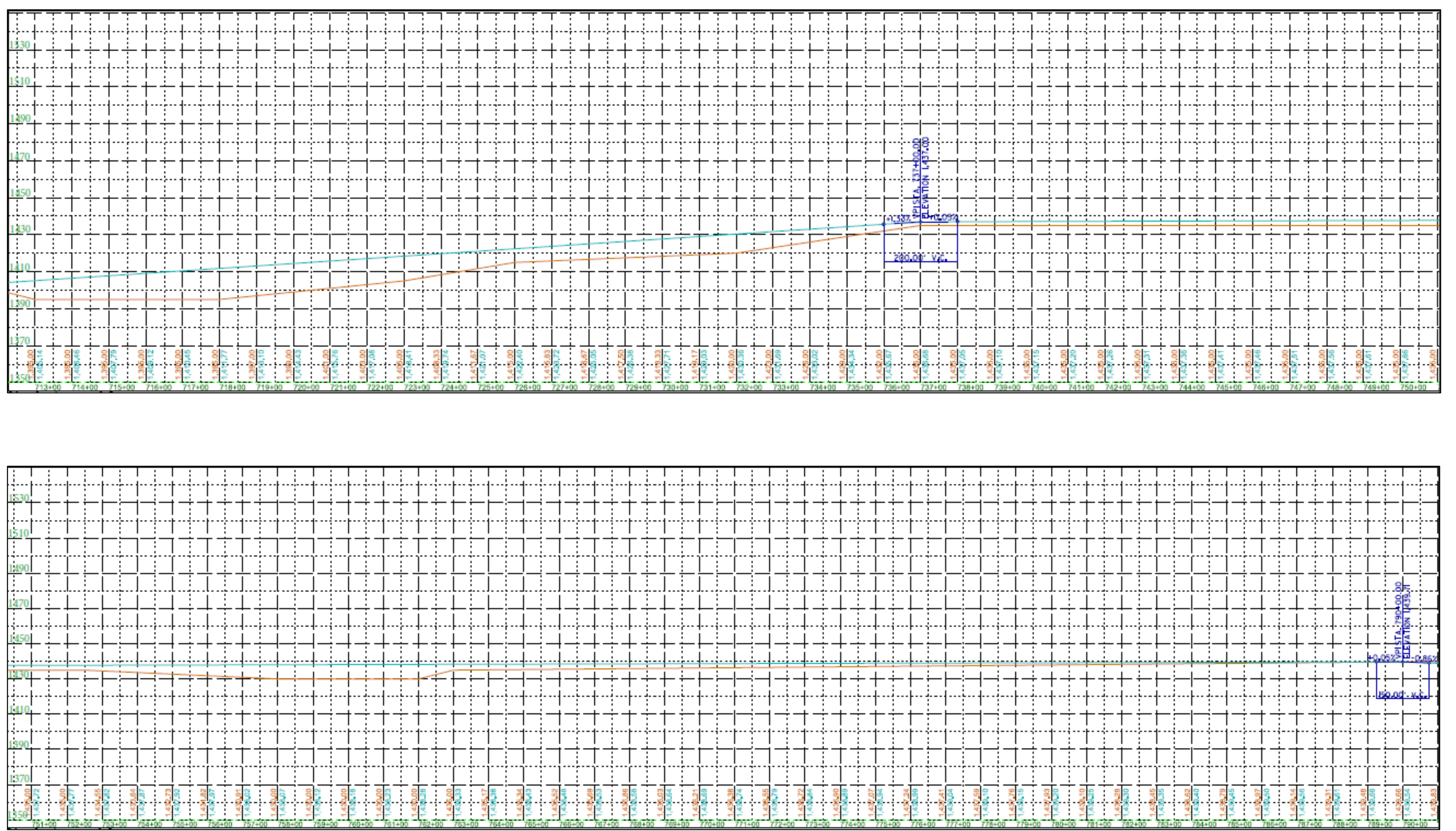

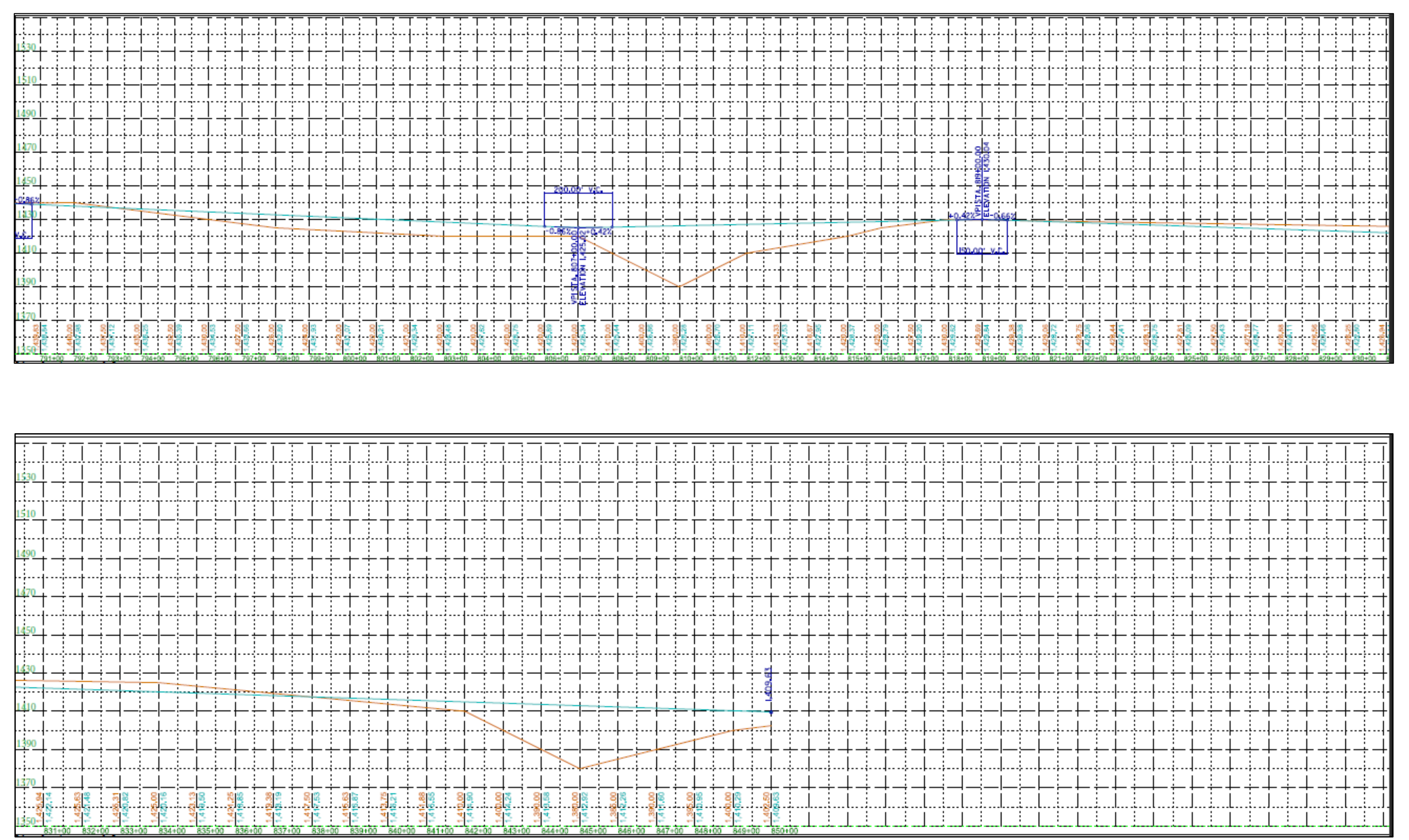

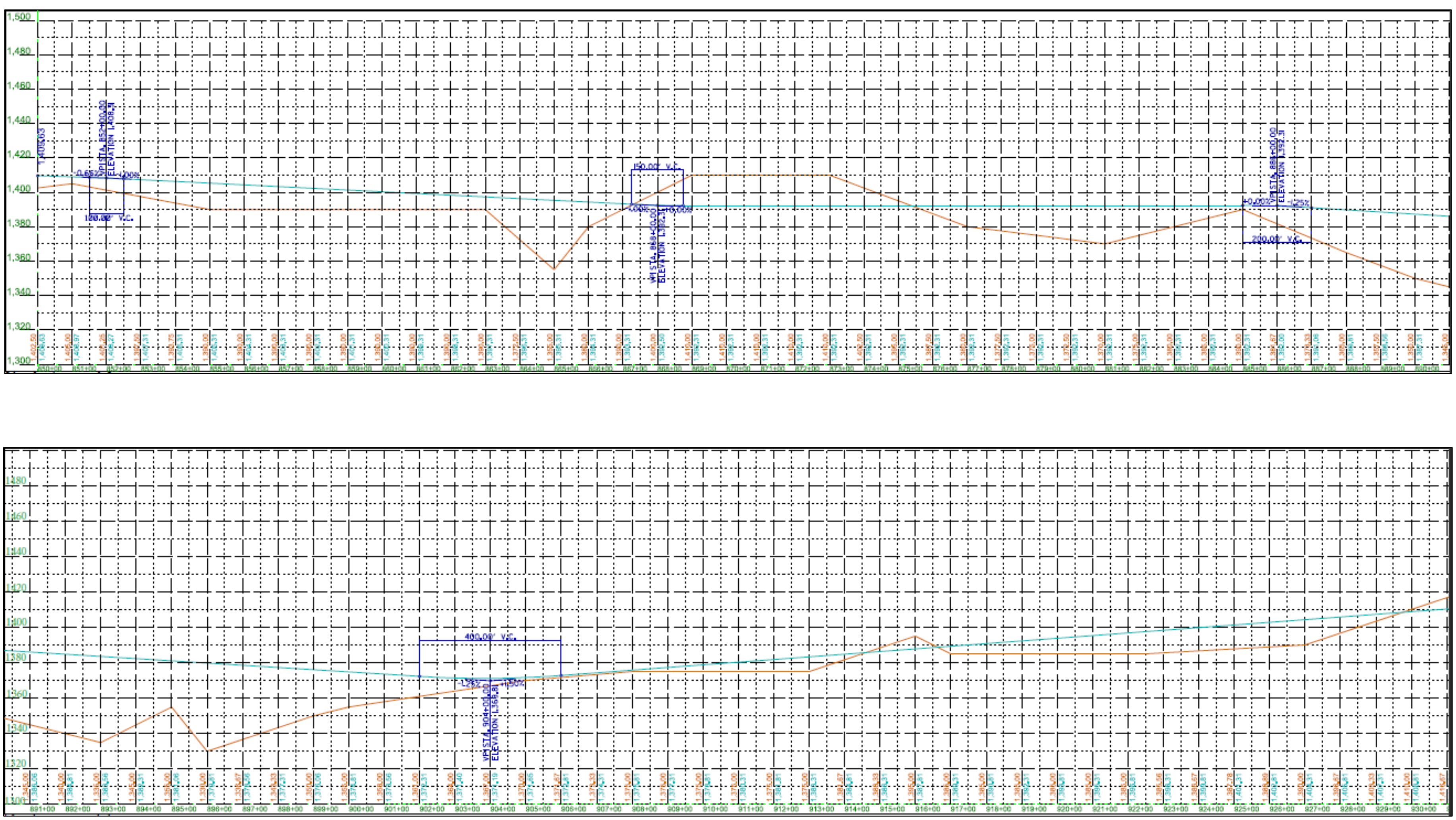

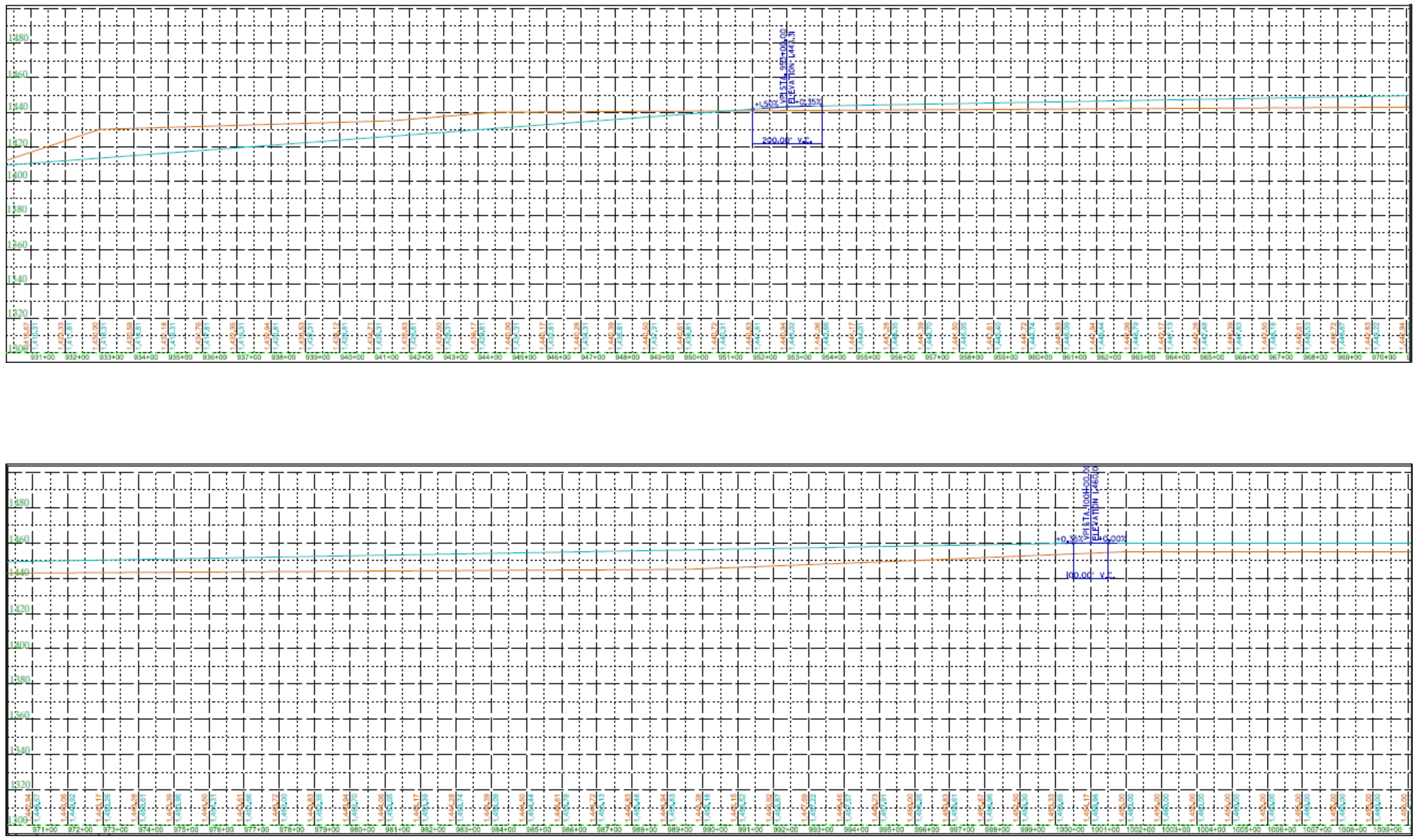

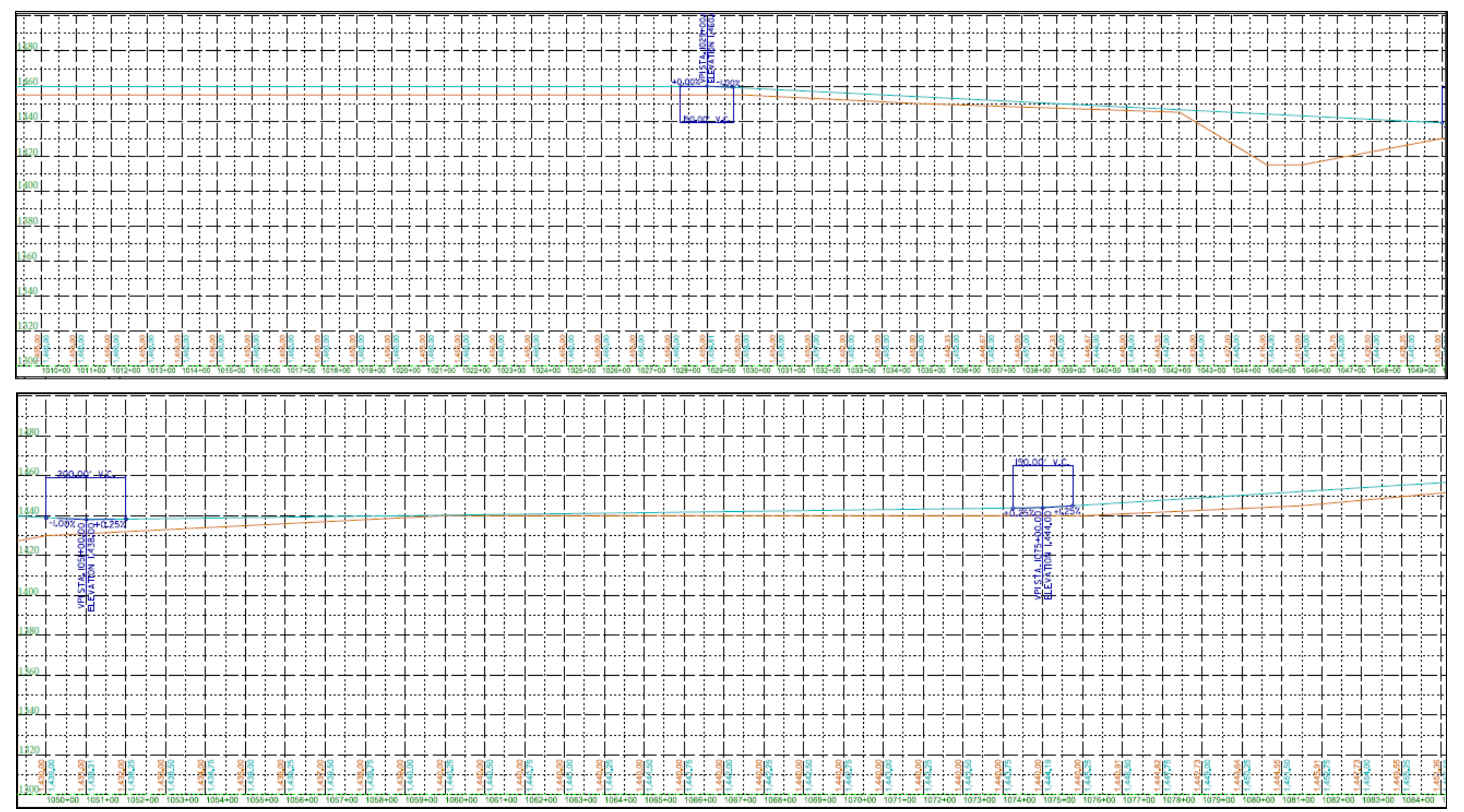


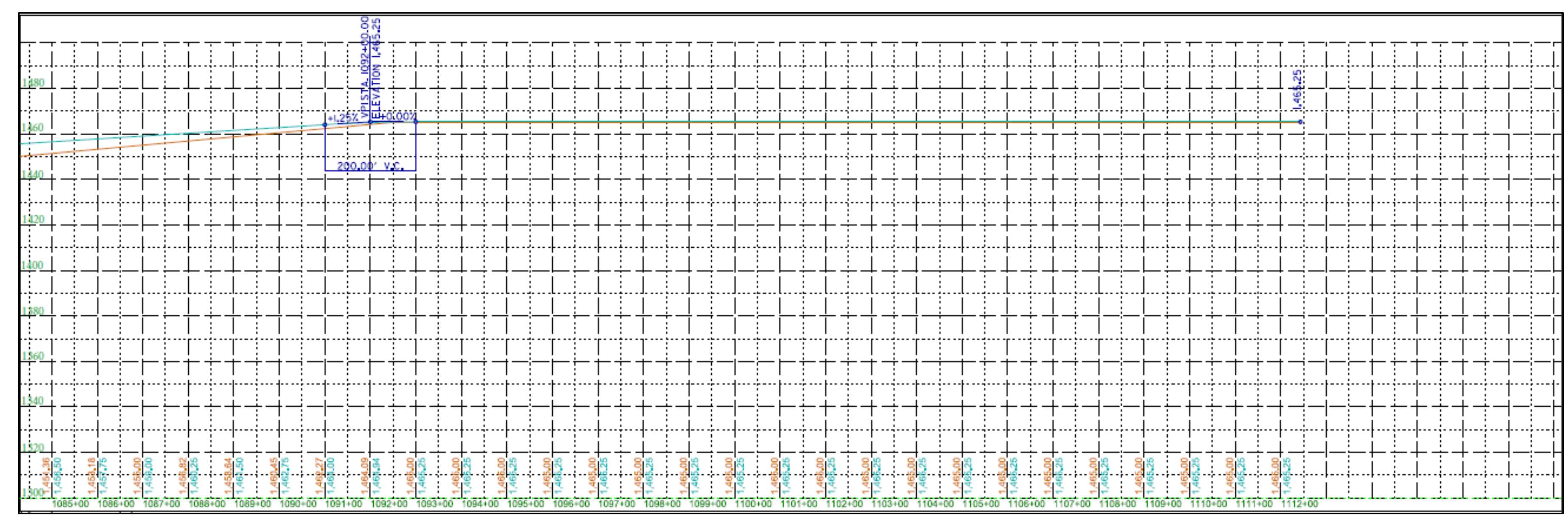




\section{Appendix-2: Details of SimaPro Datasets for all primary processes used in Detailed LCA.}

Datasets of Processes under Infrastructure Construction

\begin{tabular}{|c|c|c|c|c|}
\hline \multicolumn{5}{|c|}{ Infrastructure Construction } \\
\hline Process & Unit & Item & Dataset & Comments \\
\hline \multirow[t]{4}{*}{$\begin{array}{l}\text { Road } \\
\text { Reconstruction }\end{array}$} & \multirow[t]{4}{*}{ Per mile } & $\begin{array}{l}\text { Hot Mix Asphalt } \\
\text { (HMA) }\end{array}$ & $\begin{array}{l}\text { LCA Highland Copper } \\
\text { HMA }\end{array}$ & $\begin{array}{l}\text { Custom Dataset, } \\
\text { Created using the } \\
\text { quantities of gravel and } \\
\text { asphalt present in HMA } \\
\text { (see Table 7) }\end{array}$ \\
\hline & & Gravel & $\begin{array}{l}\text { Gravel, crushed (GLO)| } \\
\text { market for | Alloc Def, U }\end{array}$ & \\
\hline & & Sand & $\begin{array}{l}\text { Sand (GLO)| market for | } \\
\text { Alloc Def, U }\end{array}$ & \\
\hline & & Fuel & $\begin{array}{l}\text { Diesel production and } \\
\text { emissions from diesel } \\
\text { burned }\end{array}$ & $\begin{array}{l}\text { The quantities of fuel } \\
\text { consumed per mile of } \\
\text { road construction were } \\
\text { calculated using } \\
\text { literature values. }\end{array}$ \\
\hline \multirow[t]{4}{*}{$\begin{array}{l}\text { Track } \\
\text { Construction }\end{array}$} & \multirow[t]{3}{*}{ Per mile } & Gravel & $\begin{array}{l}\text { Gravel, crushed (GLO)| } \\
\text { market for | Alloc Def, U }\end{array}$ & For ballast \\
\hline & & Steel & $\begin{array}{l}\text { Steel, low-alloyed, hot } \\
\text { rolled (GLO)| market for | } \\
\text { Alloc Def, U }\end{array}$ & $\begin{array}{l}\text { For rail, spikes and tie } \\
\text { plates }\end{array}$ \\
\hline & & Timber & $\begin{array}{l}\text { Sawn timber, hardwood, } \\
\text { planed, air/kiln dried, } \\
\text { u=10\% at plant/US- US-EI } \\
\text { U }\end{array}$ & For ties \\
\hline & & Fuel & $\begin{array}{l}\text { Diesel production and } \\
\text { emissions from diesel } \\
\text { burned }\end{array}$ & $\begin{array}{l}\text { The quantities of fuel } \\
\text { consumed per mile of } \\
\text { track construction were } \\
\text { calculated using } \\
\text { literature values. }\end{array}$ \\
\hline
\end{tabular}


Hot Mix Asphalt (HMA) Custom Dataset - Quantities and Calculations

\begin{tabular}{|c|c|c|c|}
\hline Sub Item & Unit & Quantity & Source/Calculations/Comments \\
\hline \multicolumn{4}{|c|}{ LCA Highland Copper HMA Data } \\
\hline $\begin{array}{l}\text { Percent of } \\
\text { Bitumen by } \\
\text { volume in unit } \\
\text { of HMA }\end{array}$ & $\%$ & 8 & $\begin{array}{l}\text { NCHRP Report } 673 \text { - A manual for Design of hot mix } \\
\text { asphalt with Commentary }\end{array}$ \\
\hline $\begin{array}{l}\text { Percent of } \\
\text { Aggregates by } \\
\text { volume in unit } \\
\text { of HMA }\end{array}$ & $\%$ & 88 & $\begin{array}{l}\text { NCHRP Report } 673 \text { - A manual for Design of hot mix } \\
\text { asphalt with Commentary }\end{array}$ \\
\hline $\begin{array}{l}\text { Density of } \\
\text { Bitumen }\end{array}$ & Lbs./cu.ft & 45 & \\
\hline $\begin{array}{l}\text { Density of } \\
\text { Aggregates }\end{array}$ & Lbs./cu.ft & 95 & \\
\hline $\begin{array}{l}\text { Tons of Bitumen } \\
\text { per Cu ft. of } \\
\text { HMA }\end{array}$ & tons & 0.0018 & $\begin{array}{l}\text { Calculation - } 1 \text { cu ft. of HMA *percent of bitumen by } \\
\text { volume in } 1 \mathrm{cu} f \mathrm{ft} \text { of HMA * density of bitumen / } \\
2,000 \text { lbs. ( } 1 \text { ton) }\end{array}$ \\
\hline $\begin{array}{l}\text { Tons of } \\
\text { Aggregates per } \\
\text { Cu ft. of HMA }\end{array}$ & tons & 0.042 & $\begin{array}{l}\text { Calculation - } 1 \mathrm{cu} \mathrm{ft} \text {. of HMA * percent of aggregates } \\
\text { by volume in } 1 \mathrm{cu} \mathrm{ft} \text {. of HMA * density of bitumen / } \\
2,000 \text { lbs. ( } 1 \text { ton) }\end{array}$ \\
\hline
\end{tabular}


Road Reconstruction (Heavy) Process - Quantities and Calculations per mile

\begin{tabular}{|c|c|c|c|}
\hline \multirow{2}{*}{\multicolumn{4}{|c|}{$\begin{array}{l}\text { Item Unit } \quad \text { Quantity } \\
\text { Road Reconstruction (Heavy) - Data }\end{array}$}} \\
\hline & & & \\
\hline $\begin{array}{l}\text { Depth of sand } \\
\text { leveling }\end{array}$ & feet & 2 & \multirow[t]{5}{*}{$\begin{array}{l}\text { Gogebic county road commission and Marquette } \\
\text { county road commission road section sheets }\end{array}$} \\
\hline Aggregate depth & inches & 12 & \\
\hline HMA depth & inches & 6 & \\
\hline $\begin{array}{l}\text { Width of sub } \\
\text { base }\end{array}$ & feet & 40 & \\
\hline Width of HMA & feet & 28 & \\
\hline $\begin{array}{l}\text { Density of } \\
\text { Aggregates }\end{array}$ & Lbs./cu.ft & 95 & \\
\hline Density of Sand & Lbs./cu.ft & 100 & \\
\hline \multicolumn{4}{|c|}{ Road Reconstruction (Heavy) - Calculations } \\
\hline $\begin{array}{l}\text { Volume of sand } \\
\text { per mile }\end{array}$ & Cu.ft/mile & 422,400 & Calculation - depth* width* 5,280 ft. (1mile) \\
\hline $\begin{array}{l}\text { Volume of } \\
\text { aggregate per } \\
\text { mile }\end{array}$ & Cu.ft/mile & 211,200 & Calculation - depth* width* 5,280 ft. (1mile) \\
\hline \multicolumn{4}{|c|}{ Road Reconstruction (Heavy) - Values for SimaPro Datasets } \\
\hline $\begin{array}{l}\text { Volume of HMA } \\
\text { per mile }\end{array}$ & Cu.ft/mile & 73,920 & Calculation - depth* width* 5,280 ft. (1mile) \\
\hline $\begin{array}{l}\text { Weight of sand } \\
\text { per mile }\end{array}$ & tons & 21,120 & \multirow[t]{2}{*}{$\begin{array}{l}\text { The volume from calculations is converted to tons } \\
\text { using the density value }\end{array}$} \\
\hline $\begin{array}{l}\text { Weight of } \\
\text { aggregate per } \\
\text { mile }\end{array}$ & tons & 10,032 & \\
\hline Fuel & Gal / mile & 9696 & $\begin{array}{l}\text { The total fuel consumption per mile of road } \\
\text { reconstruction }\end{array}$ \\
\hline
\end{tabular}


Track Construction Process - Quantities and Calculations per mile

\begin{tabular}{|c|c|c|c|}
\hline Item & Unit & Quantity & Source/Calculations/Comments \\
\hline \multicolumn{4}{|c|}{ Track Construction - Data } \\
\hline $\begin{array}{l}\text { Number of ties } \\
\text { per mile }\end{array}$ & Each & 2,947 & 21.5" c/c tie spacing, MHF services \\
\hline $\begin{array}{l}\text { Quantity of } \\
\text { wood per tie }\end{array}$ & cu ft. & 3.7 & $\begin{array}{l}\text { 7" * 9" * 8.5' (Tie dimensions) } \\
\text { http://www.rta.org/faqs-main }\end{array}$ \\
\hline $\begin{array}{l}\text { Weight of tie } \\
\text { plate }\end{array}$ & Lbs. & 17.87 & $\begin{array}{l}\text { 6" width rail, AREMA plan } 10 \\
\text { http://harmersteel.com/hs/wp- } \\
\text { content/catalog/cache/harmer-steel-catalog- } \\
\text { 2014/48.pdf }\end{array}$ \\
\hline $\begin{array}{l}\text { number of } \\
\text { spikes per } 200 \\
\text { lbs. keg }\end{array}$ & Each & 360 & $\begin{array}{l}\text { standard spike size is } 5.5 \text { in long } \\
\text { http://sizes.com/tools/spikes_railroad.htm }\end{array}$ \\
\hline Type of rail & Lbs./yd. & 136 & MHF Services \\
\hline $\begin{array}{l}\text { Volume of } \\
\text { ballast per } \\
\text { mile }\end{array}$ & tons & 10,000 & MHF Services \\
\hline $\begin{array}{l}\text { Volume of } \\
\text { sand per mile } \\
\text { (Track bed) }\end{array}$ & tons/mile & 3762 & Calculation - depth*width*5280 (1-mile) \\
\hline
\end{tabular}

\section{Track Construction- Values entered into SimaPro Datasets}

\begin{tabular}{|l|c|c|l|}
\hline $\begin{array}{l}\text { Weight of } \\
\text { Steel for rail, } \\
\text { per mile }\end{array}$ & tons/mile & 240 & $\begin{array}{l}\text { Calculation - conversion of lbs./yd. to tons/mile * two } \\
\text { rails }\end{array}$ \\
\hline $\begin{array}{l}\text { Volume of } \\
\text { timber for ties } \\
\text { per mile }\end{array}$ & Cu.ft./mile & 11,000 & $\begin{array}{l}\text { Calculation - number of ties per mile * volume of } \\
\text { wood per tie }\end{array}$ \\
\hline $\begin{array}{l}\text { Weight of steel } \\
\text { for tie plates } \\
\text { per mile }\end{array}$ & tons/mile & 53 & $\begin{array}{l}\text { Calculation - Number of ties per mile * 2 plates per tie } \\
\text { / 2,000 lbs. (1 ton) }\end{array}$ \\
\hline $\begin{array}{l}\text { Weight of steel } \\
\text { for spikes }\end{array}$ & tons/mile & 3.3 & $\begin{array}{l}\text { Calculation - Number of ties per mile * 4 spikes per } \\
\text { tie / spikes per keg * weight of one keg/2,000lbs }(1 \\
\text { ton) }\end{array}$ \\
\hline Fuel & Gal/mile & 4909 & $\begin{array}{l}\text { The total fuel consumption per mile of track } \\
\text { construction (Clearing, track bed and ballast) }\end{array}$ \\
\hline
\end{tabular}


Datasets for Processes under Rolling Stock Manufacturing

\begin{tabular}{|c|c|c|c|}
\hline Process & Unit & Item & Dataset \\
\hline \multirow{3}{*}{$\begin{array}{l}\text { Truck } \\
\text { Manufacturing } \\
\text { and }\end{array}$} & \multirow[t]{3}{*}{ Per truck } & Steel & $\begin{array}{l}\text { Steel, low-alloyed, hot rolled (GLO)| market for | Alloc } \\
\text { Def, U }\end{array}$ \\
\hline & & Aluminum & $\begin{array}{l}\text { Aluminium, cast alloy (GLO)| market for | Alloc Def, } \\
\text { U }\end{array}$ \\
\hline & & $\begin{array}{l}\text { Manufacturing } \\
\text { Process }\end{array}$ & $\begin{array}{l}\text { Metal working, average for metal product } \\
\text { manufacturing (RER)| processing | Alloc Def, U }\end{array}$ \\
\hline \multirow[t]{2}{*}{$\begin{array}{l}\text { Truck Tire } \\
\text { manufacturing }\end{array}$} & \multirow[t]{2}{*}{ Per Tire } & Rubber & $\begin{array}{l}\text { Acrylonitrile-butadiene-styrene copolymer (RER)| } \\
\text { production | Alloc Def, U }\end{array}$ \\
\hline & & Processing & Injection moulding (GLO)| market for | Alloc Def, U \\
\hline \multirow{2}{*}{$\begin{array}{l}\text { Locomotive } \\
\text { Manufacturing } \\
\text { and } \\
\text { Rail car } \\
\text { manufacturing }\end{array}$} & \multirow[t]{2}{*}{ Per Unit } & Steel & $\begin{array}{l}\text { Steel, low-alloyed, hot rolled (GLO)| market for | Alloc } \\
\text { Def, U }\end{array}$ \\
\hline & & $\begin{array}{l}\text { Manufacturing } \\
\text { Process }\end{array}$ & $\begin{array}{l}\text { Metal working, average for metal product } \\
\text { manufacturing (RER)| processing | Alloc Def, U }\end{array}$ \\
\hline
\end{tabular}


Truck Manufacturing Process - Quantities and Calculations per Truck

\begin{tabular}{|c|c|c|c|}
\hline Item & Unit & Quantity & Source/Comments \\
\hline \multicolumn{4}{|c|}{ Truck Manufacturing - Data } \\
\hline $\begin{array}{l}\text { Loaded Truck } \\
\text { Weight }\end{array}$ & tons & 76 & $\begin{array}{l}\text { Van Damme trucking, Michigan maximum truck } \\
\text { weight, 164,000 lbs. ( } 82 \text { tons) }\end{array}$ \\
\hline $\begin{array}{l}\text { Capacity of } \\
\text { truck }\end{array}$ & tons & 45 & Van Damme trucking, \\
\hline $\begin{array}{l}\text { Empty truck } \\
\text { weight }\end{array}$ & tons & 31 & \\
\hline $\begin{array}{l}\text { Number of tires } \\
\text { per truck }\end{array}$ & \# & 42 & Van Damme trucking \\
\hline Weight of tires & Lbs. & 130 & $\begin{array}{l}\text { Weight of each tire, Size of tire from Van Damme } \\
\text { trucking, weight from Michelin tire website }\end{array}$ \\
\hline $\begin{array}{l}\text { Total weight of } \\
\text { tires }\end{array}$ & tons & 2.73 & \\
\hline $\begin{array}{l}\text { Weight of truck } \\
\text { without tires }\end{array}$ & tons & 28.27 & \\
\hline \multicolumn{4}{|c|}{ Truck Manufacturing - Values entered into SimaPro Datasets } \\
\hline Quantity of steel & tons & 18.38 & Assuming $65 \%$ truck components are steel \\
\hline $\begin{array}{l}\text { Quantity of } \\
\text { aluminum }\end{array}$ & tons & 7.07 & Assuming $25 \%$ truck components are aluminum \\
\hline $\begin{array}{l}\text { Weight of tire in } \\
\text { tons }\end{array}$ & tons & 0.065 & \\
\hline
\end{tabular}


Locomotive and Rail Car Manufacturing Process - Quantities and Calculations per unit

\begin{tabular}{|c|c|c|c|}
\hline Item & Unit & Quantity & Source/Comments \\
\hline \multicolumn{4}{|c|}{ Locomotive Manufacturing - Data } \\
\hline $\begin{array}{l}\text { Locomotive } \\
\text { Weight }\end{array}$ & tons & 125 & GATX website \\
\hline \multicolumn{4}{|c|}{ Locomotive Manufacturing - Values entered into SimaPro Datasets } \\
\hline Quantity of steel & tons & 112.5 & $90 \%$ of locomotive is made of steel \\
\hline \multicolumn{4}{|c|}{ Rail Car Manufacturing - Data } \\
\hline $\begin{array}{l}\text { Gross weight of } \\
\text { Rail car }\end{array}$ & tons & 131.5 & $\begin{array}{l}\text { weight of car + load, Data from MHF suggested } \\
263,000 \text { lbs. operations }\end{array}$ \\
\hline $\begin{array}{l}\text { Net Weight of } \\
\text { Rail car }\end{array}$ & tons & 100 & MHF Data \\
\hline $\begin{array}{l}\text { Empty Rail car } \\
\text { weight }\end{array}$ & tons & 31.5 & \\
\hline \multicolumn{4}{|c|}{ Rail Car Manufacturing - Values entered into SimaPro Datasets } \\
\hline $\begin{array}{l}\text { Quantity of steel } \\
\text { per rail car }\end{array}$ & tons & 31.5 & Assuming complete steel for rail car \\
\hline
\end{tabular}

Datasets of Processes under Infrastructure Maintenance

\begin{tabular}{|c|c|c|c|c|}
\hline \multicolumn{5}{|c|}{ Infrastructure Maintenance } \\
\hline Processes & Unit & Item & Datasets & Comments \\
\hline \multirow[t]{3}{*}{$\begin{array}{l}\text { Track } \\
\text { Maintenance }\end{array}$} & \multirow[t]{3}{*}{ Per mile } & Gravel & $\begin{array}{l}\text { Gravel, crushed (GLO)| } \\
\text { market for | Alloc Def, U }\end{array}$ & For ballast \\
\hline & & Steel & $\begin{array}{l}\text { Steel, low-alloyed, hot } \\
\text { rolled (GLO)| market for | } \\
\text { Alloc Def, U }\end{array}$ & $\begin{array}{l}\text { For rail, spikes and tie } \\
\text { plates }\end{array}$ \\
\hline & & Timber & $\begin{array}{l}\text { Sawn timber, softwood, } \\
\text { planed, air dried, at } \\
\text { plant/US- US-EI U }\end{array}$ & For ties \\
\hline
\end{tabular}


Track Maintenance Process- Quantities and Calculation per mile

\begin{tabular}{|c|c|c|c|}
\hline Item & Unit & Quantity & Source/Comments \\
\hline \multicolumn{4}{|c|}{ Track Rehabilitation - Data } \\
\hline $\begin{array}{l}\text { Number of ties } \\
\text { per mile }\end{array}$ & $\#$ & 420 & $\begin{array}{l}14 \% \text { of ties per mile of track upgraded with spot fixes } \\
\text { within a five year period }\end{array}$ \\
\hline $\begin{array}{l}\text { Quantity of } \\
\text { wood per tie }\end{array}$ & cu ft & 3.7 & 7" * 9" * 8.5' http://www.rta.org/faqs-main \\
\hline $\begin{array}{l}\text { Volume of } \\
\text { ballast per mile }\end{array}$ & tons & 2,000 & $\begin{array}{l}20 \% \text { of quantities of new track construction every five } \\
\text { years, assumed value }\end{array}$ \\
\hline \multicolumn{4}{|c|}{ Track Rehabilitation - Values entered into SimaPro Datasets } \\
\hline $\begin{array}{l}\text { Volume of } \\
\text { timber for ties } \\
\text { per mile }\end{array}$ & cuft/mile & 1554 & $\begin{array}{l}\text { Calculation - number of ties per mile * volume of } \\
\text { wood per tie }\end{array}$ \\
\hline $\begin{array}{l}\text { Volume of } \\
\text { ballast per mile }\end{array}$ & tons & 1500 & $\begin{array}{l}15 \% \text { of quantities of ballast replaced every } 10 \text { years } \\
\text { (calculated based on } 15 \% \text { replacement every } 15 \\
\text { million ton Miles) }\end{array}$ \\
\hline
\end{tabular}

\section{Datasets for Processes under Rolling Stock Maintenance}

\begin{tabular}{|l|c|c|c|}
\hline \multicolumn{2}{|c}{ Processes } & \multicolumn{2}{c|}{ Item } \\
\hline $\begin{array}{l}\text { Truck and } \\
\text { Locomotive } \\
\text { maintenance }\end{array}$ & Per cycle & Lubricating oil & Lubricating oil (GLO)| market for | Alloc Def, S \\
\hline $\begin{array}{l}\text { Truck Tire } \\
\text { maintenance }\end{array}$ & Per Tire & Rubber & $\begin{array}{l}\text { Acrylonitrile-butadiene-styrene copolymer (RER)| } \\
\text { production | Alloc Def, U }\end{array}$ \\
\cline { 3 - 4 } & & Processing & Injection moulding (GLO)| market for | Alloc Def, U \\
\hline
\end{tabular}


Truck Maintenance Process - Quantities and Calculations per mile

\begin{tabular}{|c|c|c|c|}
\hline Item & Unit & Quantity & Source/Comments \\
\hline Truck Mainter & $\mathbf{e}-\mathbf{O}$ & cement D & \\
\hline $\begin{array}{l}\text { Quantity of oil } \\
\text { replaced per } \\
\text { maintenance } \\
\text { cycle }\end{array}$ & gal & 11.00 & Van Damme trucking \\
\hline Density of oil & $\mathrm{kg} / \mathrm{l}$ & 0.85 & \\
\hline $\begin{array}{l}\text { quantity of oil in } \\
\text { liters }\end{array}$ & lit & 41.64 & \\
\hline $\begin{array}{l}\text { Distance } \\
\text { travelled by } \\
\text { truck in one } \\
\text { day }\end{array}$ & miles & 320 & $\begin{array}{l}\text { For option B, round trip } 16 \text { miles, } \\
\text { Calculation - } 140 \text { truck trips per day } * 16 / \text { number of } \\
\text { miles }\end{array}$ \\
\hline $\begin{array}{l}\text { Distance } \\
\text { travelled by } \\
\text { truck in one } \\
\text { year }\end{array}$ & miles & 116,800 & \\
\hline $\begin{array}{l}\text { number of } \\
\text { maintenance } \\
\text { cycles per year }\end{array}$ & \# & 7.79 & $\begin{array}{l}\text { Calculation - distance travelled per year / 15,000 } \\
\text { miles (maintenance interval) }\end{array}$ \\
\hline Truck Mainter & $-\mathbf{O}$ & cement V & s entered into SimaPro Datasets \\
\hline $\begin{array}{l}\text { Weight of oil } \\
\text { per } \\
\text { maintenance } \\
\text { cycle }\end{array}$ & $\mathrm{kg}$ & 35.39 & $\begin{array}{l}\text { Calculation - Quantity of oil in liters per maintenance } \\
\text { cycle * density of oil }\end{array}$ \\
\hline $\begin{array}{l}\text { Truck } \\
\text { Maintenance } \\
\text { Cycles over life }\end{array}$ & \# & 1,090 & $\begin{array}{l}\text { Calculation - number of maintenance cycles per year } \\
* \text { number of trucks * life }\end{array}$ \\
\hline
\end{tabular}




\section{Appendix-3: Detailed LCA Results}

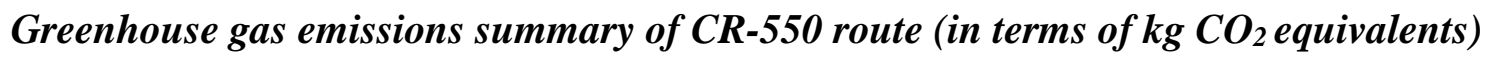

\begin{tabular}{|c|c|c|c|c|c|c|}
\hline \multicolumn{7}{|c|}{ Greenhouse Gas Emissions Summary Of CR-550 Route (In Terms Of $\mathrm{Kg} \mathrm{CO}_{2}$ Equivalents) } \\
\hline SL \# & Item & 8-years & 9-years & 10-years & 15-years & 20-years \\
\hline \multicolumn{7}{|c|}{ Construction Phase } \\
\hline 1. & $\begin{array}{l}\text { Heavy road } \\
\text { reconstruction }\end{array}$ & $8.17 \mathrm{E}+06$ & 8.17E+06 & $8.17 \mathrm{E}+06$ & 8.17E+06 & 8.17E+06 \\
\hline 2. & $\begin{array}{l}\text { Light road } \\
\text { reconstruction }\end{array}$ & $1.29 \mathrm{E}+06$ & $1.29 \mathrm{E}+06$ & $1.29 \mathrm{E}+06$ & $1.29 \mathrm{E}+06$ & $1.29 \mathrm{E}+06$ \\
\hline 3. & Truck manufacturing & $4.50 \mathrm{E}+06$ & $4.93 \mathrm{E}+06$ & $5.36 \mathrm{E}+06$ & $7.60 \mathrm{E}+06$ & $1.02 \mathrm{E}+07$ \\
\hline 4. & Tires manufacturing & $1.33 \mathrm{E}+05$ & $1.33 \mathrm{E}+05$ & $1.33 \mathrm{E}+05$ & $1.33 \mathrm{E}+05$ & $1.33 \mathrm{E}+05$ \\
\hline 5. & Total & $1.41 E+07$ & $1.45 \mathrm{E}+07$ & $1.50 \mathrm{E}+07$ & $1.72 E+07$ & $1.97 E+07$ \\
\hline \multicolumn{7}{|c|}{ Operations Phase } \\
\hline 1. & Diesel production & $9.07 \mathrm{E}+06$ & $1.02 \mathrm{E}+07$ & $1.13 \mathrm{E}+07$ & $1.70 \mathrm{E}+07$ & $2.26 \mathrm{E}+07$ \\
\hline 2. & Truck operation & $4.81 \mathrm{E}+07$ & $5.41 \mathrm{E}+07$ & $6.01 \mathrm{E}+07$ & $9.01 \mathrm{E}+07$ & $1.20 \mathrm{E}+08$ \\
\hline 3. & Total & $5.72 E+07$ & $6.43 E+07$ & $7.15 E+07$ & $1.07 E+08$ & $1.43 E+08$ \\
\hline \multicolumn{7}{|c|}{ Maintenance Phase } \\
\hline 1. & Tire replacement & $2.23 \mathrm{E}+06$ & $2.50 \mathrm{E}+06$ & $2.78 \mathrm{E}+06$ & $4.17 \mathrm{E}+06$ & $5.56 \mathrm{E}+06$ \\
\hline 2. & Truck maintenance & $4.87 \mathrm{E}+04$ & $5.47 \mathrm{E}+04$ & $6.08 \mathrm{E}+04$ & $9.12 \mathrm{E}+04$ & $1.21 \mathrm{E}+05$ \\
\hline 3. & Snow removal & $2.35 E+06$ & $2.64 \mathrm{E}+06$ & $2.93 E+06$ & $4.40 \mathrm{E}+06$ & $5.86 \mathrm{E}+06$ \\
\hline 4. & Total & $4.62 E+06$ & $5.20 \mathrm{E}+06$ & $5.78 E+06$ & $8.66 \mathrm{E}+06$ & $1.15 \mathrm{E}+07$ \\
\hline \multicolumn{2}{|c|}{ Total Overall Emissions } & $7.59 E+07$ & $8.40 E+07$ & $9.22 E+07$ & $1.33 E+08$ & $1.74 E+08$ \\
\hline
\end{tabular}


Greenhouse gas emissions Summary of CR-595 Route in terms of $\mathrm{Kg} \mathrm{CO}_{2}$ equivalents Greenhouse Gas Emissions Summary Of CR-595 Route In Terms Of $\mathrm{Kg} \mathrm{CO}_{2}$ Equivalents

\begin{tabular}{|c|c|c|c|c|c|c|}
\hline SL \# & Item & 8-years & 9-years & 10-years & 15-years & 20-years \\
\hline \multicolumn{7}{|c|}{ Construction Phase } \\
\hline 1. & $\begin{array}{l}\text { Heavy road } \\
\text { reconstruction }\end{array}$ & $1.25 \mathrm{E}+07$ & $1.25 \mathrm{E}+07$ & $1.25 \mathrm{E}+07$ & $1.25 \mathrm{E}+07$ & $1.25 \mathrm{E}+07$ \\
\hline 2. & $\begin{array}{l}\text { Light road } \\
\text { reconstruction }\end{array}$ & 0.00 & 0.00 & 0.00 & 0.00 & 0.00 \\
\hline 3. & Truck manufacturing & $1.71 \mathrm{E}+06$ & $1.82 \mathrm{E}+06$ & $2.04 \mathrm{E}+06$ & $2.89 \mathrm{E}+06$ & $3.65 E+06$ \\
\hline 4. & Tires manufacturing & $5.90 \mathrm{E}+04$ & $5.90 \mathrm{E}+04$ & $5.91 \mathrm{E}+04$ & $5.90 \mathrm{E}+04$ & $5.91 \mathrm{E}+04$ \\
\hline 5. & Total & $1.42 E+07$ & $1.43 E+07$ & $1.46 \mathrm{E}+07$ & $1.54 \mathrm{E}+07$ & $1.62 E+07$ \\
\hline \multicolumn{7}{|c|}{ Operations Phase } \\
\hline 1. & Diesel production & $3.07 \mathrm{E}+06$ & $3.45 \mathrm{E}+06$ & $3.84 \mathrm{E}+06$ & $5.76 \mathrm{E}+06$ & $7.68 \mathrm{E}+06$ \\
\hline 2. & Truck operation & $1.63 \mathrm{E}+07$ & $1.83 \mathrm{E}+07$ & $2.04 \mathrm{E}+07$ & $3.05 \mathrm{E}+07$ & $4.07 \mathrm{E}+07$ \\
\hline 3. & Total & $1.93 E+07$ & $2.18 \mathrm{E}+07$ & $2.42 \mathrm{E}+07$ & $3.63 E+07$ & $4.84 \mathrm{E}+07$ \\
\hline \multicolumn{7}{|c|}{ Maintenance Phase } \\
\hline 1. & Tire replacement & $8.22 \mathrm{E}+05$ & $9.25 \mathrm{E}+05$ & $1.03 \mathrm{E}+06$ & $1.54 \mathrm{E}+06$ & $2.06 \mathrm{E}+06$ \\
\hline 2. & Truck maintenance & $1.76 \mathrm{E}+04$ & $1.98 \mathrm{E}+04$ & $2.20 \mathrm{E}+04$ & $3.29 \mathrm{E}+04$ & $4.39 \mathrm{E}+04$ \\
\hline 3. & Snow removal & $1.56 \mathrm{E}+06$ & $1.76 \mathrm{E}+06$ & $1.96 \mathrm{E}+06$ & $2.93 \mathrm{E}+06$ & $3.91 \mathrm{E}+06$ \\
\hline 4. & Total & $2.40 \mathrm{E}+06$ & $2.70 \mathrm{E}+06$ & $3.01 E+06$ & $4.51 E+06$ & $6.01 E+06$ \\
\hline \multicolumn{2}{|c|}{ Total Overall Emissions } & $3.60 E+07$ & $3.88 E+07$ & $4.18 E+07$ & $5.62 E+07$ & $7.06 E+07$ \\
\hline
\end{tabular}


Greenhouse gas emissions summary of Rail Route in terms of $\mathrm{Kg} \mathrm{CO}_{2}$ equivalents

\begin{tabular}{|c|c|c|c|c|c|c|}
\hline \multicolumn{7}{|c|}{ Greenhouse Gas Emissions Summary Of Rail Route In Terms Of $\mathrm{Kg} \mathrm{CO}_{2}$ Equivalents } \\
\hline SL \# & Item & 8-years & 9-years & 10-years & 15-years & 20-years \\
\hline \multicolumn{7}{|c|}{ Construction Phase } \\
\hline 1. & Track Construction & $1.93 \mathrm{E}+07$ & $1.93 \mathrm{E}+07$ & $1.93 \mathrm{E}+07$ & $1.93 \mathrm{E}+07$ & $1.93 \mathrm{E}+07$ \\
\hline 2. & $\begin{array}{l}\text { Locomotive } \\
\text { Manufacturing }\end{array}$ & $4.40 \mathrm{E}+05$ & $4.40 \mathrm{E}+05$ & $4.40 \mathrm{E}+05$ & $4.40 \mathrm{E}+05$ & $4.40 \mathrm{E}+05$ \\
\hline 3. & Railcar Manufacturing & $2.47 \mathrm{E}+06$ & $2.47 \mathrm{E}+06$ & $2.47 \mathrm{E}+06$ & $2.47 \mathrm{E}+06$ & $2.47 \mathrm{E}+06$ \\
\hline 4. & Total & $2.22 \mathrm{E}+07$ & $2.22 \mathrm{E}+07$ & $2.22 \mathrm{E}+07$ & $2.22 \mathrm{E}+07$ & $2.22 \mathrm{E}+07$ \\
\hline \multicolumn{7}{|c|}{ Operations Phase } \\
\hline 1. & Diesel Production & $4.84 \mathrm{E}+05$ & $5.45 \mathrm{E}+05$ & $6.05 \mathrm{E}+05$ & $9.08 \mathrm{E}+05$ & $1.21 \mathrm{E}+06$ \\
\hline 2. & Train Operation & $2.57 \mathrm{E}+06$ & $2.89 \mathrm{E}+06$ & $3.21 \mathrm{E}+06$ & $4.81 \mathrm{E}+06$ & $6.42 \mathrm{E}+06$ \\
\hline 3. & Total & $3.05 \mathrm{E}+06$ & $3.43 \mathrm{E}+06$ & $3.81 \mathrm{E}+06$ & $5.72 \mathrm{E}+06$ & $7.63 \mathrm{E}+06$ \\
\hline \multicolumn{7}{|c|}{ Maintenance Phase } \\
\hline 1. & Track Maintenance & $9.68 \mathrm{E}+04$ & $9.68 \mathrm{E}+04$ & $8.23 \mathrm{E}+05$ & $9.19 \mathrm{E}+05$ & $1.65 \mathrm{E}+06$ \\
\hline 2. & $\begin{array}{l}\text { Locomotive } \\
\text { Maintenance }\end{array}$ & $8.96 \mathrm{E}+04$ & $1.01 \mathrm{E}+05$ & $1.12 \mathrm{E}+05$ & $1.68 \mathrm{E}+05$ & $2.24 \mathrm{E}+05$ \\
\hline 3. & Railcar Wheel Change & $8.46 \mathrm{E}+04$ & $8.46 \mathrm{E}+04$ & $1.69 \mathrm{E}+05$ & $2.54 \mathrm{E}+05$ & $3.38 \mathrm{E}+05$ \\
\hline 4. & Total & $2.71 \mathrm{E}+05$ & $2.82 E+05$ & $1.10 \mathrm{E}+06$ & $1.34 \mathrm{E}+06$ & $2.21 \mathrm{E}+06$ \\
\hline \multicolumn{2}{|c|}{ Total Overall Emissions } & $2.55 \mathrm{E}+07$ & $2.59 \mathrm{E}+07$ & $2.71 \mathrm{E}+07$ & $2.92 \mathrm{E}+07$ & $3.20 \mathrm{E}+07$ \\
\hline
\end{tabular}




\section{Appendix-4: Operational LCA Results}

\begin{tabular}{|c|c|c|c|c|}
\hline$S L \#$ & Item & CR-550 & CR-595 & Rail \\
\hline 1. & Vehicle used & $\begin{array}{l}\text { HD Truck: } \\
\text { Combination } \\
\text { Short-Haul CIDI } \\
\text { - LS Diesel }\end{array}$ & $\begin{array}{l}\text { HD Truck: } \\
\text { Combination } \\
\text { Short-Haul } \\
\text { CIDI - LS } \\
\text { Diesel }\end{array}$ & $\begin{array}{l}\text { One AC } 4400 \\
\text { Locomotive } \\
\text { with } 20 \\
\text { Hopper cars }\end{array}$ \\
\hline 2. & Fuel used & $\begin{array}{l}\text { Low Sulfur } \\
\text { Diesel }\end{array}$ & $\begin{array}{l}\text { Low Sulfur } \\
\text { Diesel }\end{array}$ & $\begin{array}{l}\text { Conventional } \\
\text { Diesel } \\
\text { (burned in an } \\
\text { AC generator) }\end{array}$ \\
\hline 2. & Emissions per ton of ore (g) & 534.29 & 10556 & 3897.6 \\
\hline 3. & Tons of ore per trip & 45 & 45 & 1980 \\
\hline 4. & Tons of ore per day & 1980 & 1980 & 1980 \\
\hline 5. & Tons of ore per year & 722700 & 722700 & 722700 \\
\hline 6. & Emissions per day (kg CO $\mathrm{CO}_{2}$ eq.) & $2.09 \mathrm{E}+04$ & $7.72 \mathrm{E}+03$ & $1.07 \mathrm{E}+03$ \\
\hline 7. & Emissions per year (kg CO $\mathrm{CO}_{2}$ eq.) & 7.63E+06 & $2.82 \mathrm{E}+06$ & $3.90 \mathrm{E}+05$ \\
\hline 8. & $\begin{array}{l}\text { Total emissions in } 8 \text { years (kg } \\
\mathrm{CO}_{2} \text { eq.) }\end{array}$ & $6.10 \mathrm{E}+07$ & $2.25 \mathrm{E}+07$ & $3.12 \mathrm{E}+06$ \\
\hline 9. & $\begin{array}{l}\text { Total emissions in } 9 \text { years }(\mathrm{kg} \\
\left.\mathrm{CO}_{2} \mathrm{eq}\right)\end{array}$ & $6.87 \mathrm{E}+07$ & $2.53 \mathrm{E}+07$ & $3.51 \mathrm{E}+06$ \\
\hline 10. & $\begin{array}{l}\text { Total emissions in } 10 \text { years }(\mathrm{kg} \\
\mathrm{CO}_{2} \text { eq) }\end{array}$ & $7.63 \mathrm{E}+07$ & $2.82 \mathrm{E}+07$ & $3.90 \mathrm{E}+06$ \\
\hline 11. & $\begin{array}{l}\text { Total emissions in } 15 \text { years ( } \mathrm{kg} \\
\mathrm{CO}_{2} \text { eq.) }\end{array}$ & $1.14 \mathrm{E}+08$ & $4.22 \mathrm{E}+07$ & $5.85 \mathrm{E}+06$ \\
\hline 12. & $\begin{array}{l}\text { Total emissions in } 20 \text { years ( } \mathrm{kg} \\
\mathrm{CO}_{2} \text { eq.) }\end{array}$ & $1.53 \mathrm{E}+08$ & $5.63 \mathrm{E}+07$ & $7.80 \mathrm{E}+06$ \\
\hline
\end{tabular}

